Portland State University

PDXScholar

$1-1-2011$

\title{
The Immortal Life of Henrietta Lacks: How a Best- Seller Diffused Online
}

Melissa Ann Shavlik

Portland State University

Follow this and additional works at: https://pdxscholar.library.pdx.edu/open_access_etds Let us know how access to this document benefits you.

\section{Recommended Citation}

Shavlik, Melissa Ann, "The Immortal Life of Henrietta Lacks: How a Best-Seller Diffused Online" (2011). Dissertations and Theses. Paper 153.

https://doi.org/10.15760/etd.153

This Thesis is brought to you for free and open access. It has been accepted for inclusion in Dissertations and Theses by an authorized administrator of PDXScholar. Please contact us if we can make this document more accessible: pdxscholar@pdx.edu. 
The Immortal Life of Henrietta Lacks: How a Best-Seller Diffused Online

by

Melissa Ann Shavlik

A thesis submitted in partial fulfillment of the

requirements for the degree of

Master of Science

in

Communication Studies

Thesis Committee:

Cynthia-Lou Coleman, Chair

L. David Ritchie

William Becker

Portland State University

(C)2011 


\begin{abstract}
This study describes how information spread on the internet by examining diffusion, framing and source use surrounding coverage of the 2010 best-selling book, The Immortal Life of Henrietta Lacks. The book presented a rare opportunity to view how a story about science, discovery and race became a best-seller within weeks after its publication. Through a mixed-methods and case study approach, the author examines patterns of coverage using Google Alerts that traced the book's online coverage in the first six months of its release. The author found that online information clustered around several themes with the most prominent describing aspects of science and scientific discovery, followed by the book's characterization as a "best seller" or "good read." Another recurring theme centered on issues surrounding exploitation in human research. In addition, the study reveals that sources who "set the frame" for coverage were most likely to be media figures, including Oprah Winfrey, Alan Ball and HBO films, in addition to newspapers and individual journalists and science writers. By examining the relationship of online frames with sources, the author found that a diversity of frames is paired with key sources: that is, multiple themes co-occur with source mentions, although the themes may not have been generated by the sources themselves. Rather, sources are linked to narrative frames by others who generate online coverage. The author concludes that, while key sources initially set a message's frame, once diffused, the message may take on other qualities.
\end{abstract}




\section{DEDICATION}

This undertaking is dedicated to my parents, Joseph and Regina Shavlik. In the words of Tina Fey, "I made this out of macaroni for you." 


\section{ACKNOWLEDGEMENTS}

I would like to extend my gratitude to my thesis advisor, Dr. Cynthia-Lou Coleman. Through her expert guidance I have grown as a writer, and her patience is unparalleled. I would also like the other two members of my thesis committee, Dr. David Ritchie and Dr. William Becker. I appreciate their time and feedback throughout this process. I would like to acknowledge the individuals who assisted in the confirmatory exercise of this study: Chris Cardiel, Maryjane Dunne, Jenny Fillion, Ryan Hofer, Meghan Kearney, Ilona Malenkovich, William Jacob Amadeus Pinnock, Sean Rains, Sara Szatmary, Robert Thatch and Jaqueline Vo.

A special thanks in order for the University Club of Portland for providing a fellowship to help make this research possible. I would also like to thank the Office of the Graduate Studies for their fellowship endorsement. I would also like to thank my employer, the Northwest Power and Conservation Council, for granting me the flexibility to complete my research.

Last, but certainly not least, I'd like to thank those who have provided support during this journey, specifically: David Thelen, Katelyn Bessette, Marta Barberini, Stacy Austin, and Andi Prewitt. 


\section{TABLE OF CONTENTS}

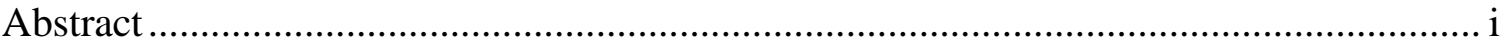

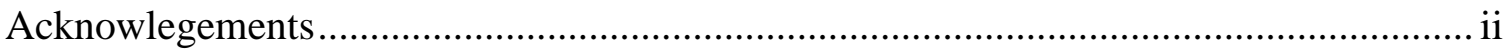

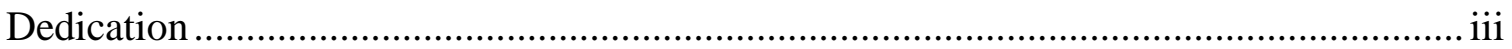

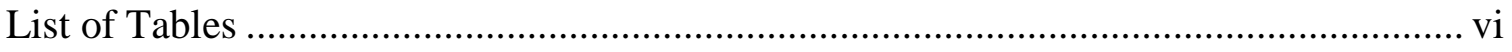

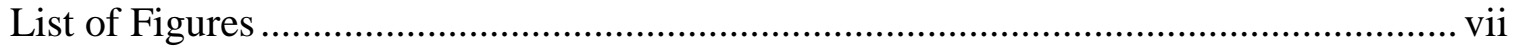

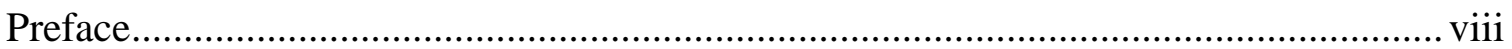

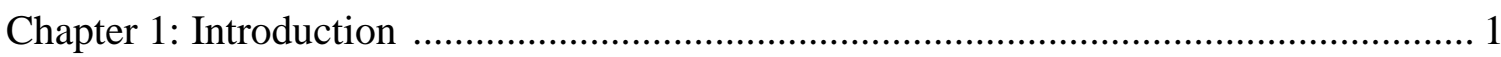

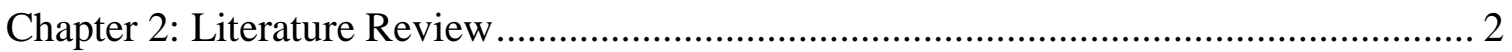

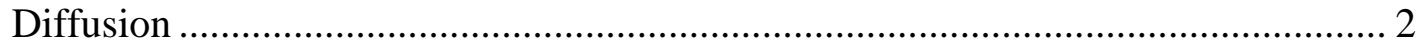

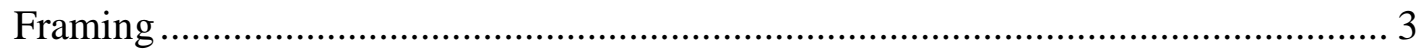

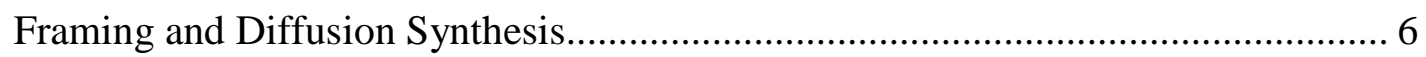

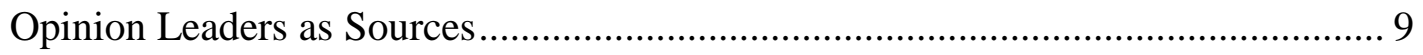

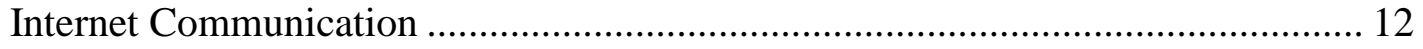

The Immortal Life of Henrietta Lacks............................................................ 15

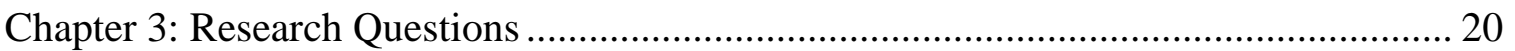

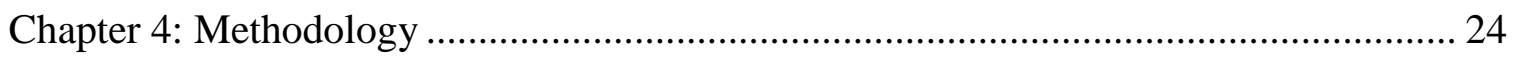

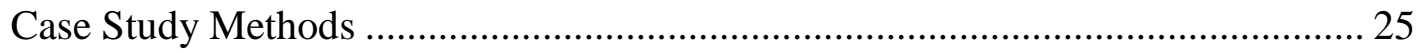

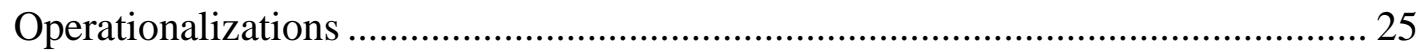


Procedure

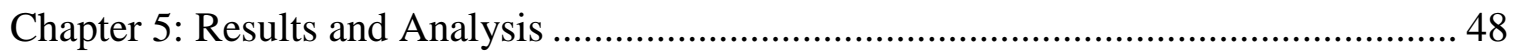

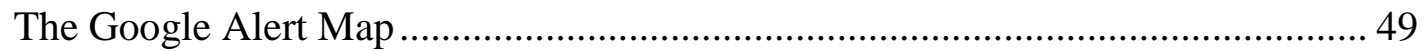

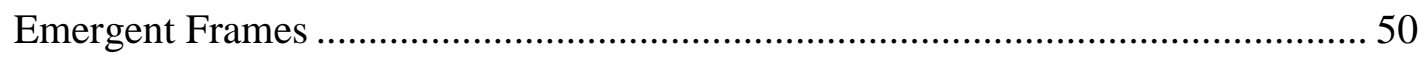

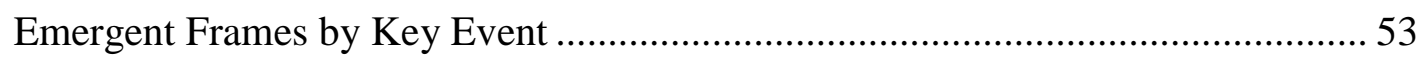

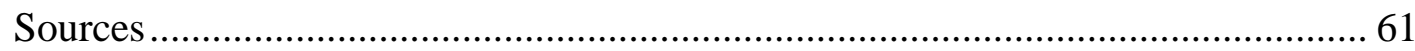

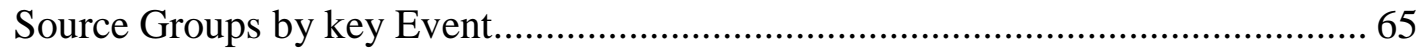

Comparing Sources to Frame Categories ..................................................... 69

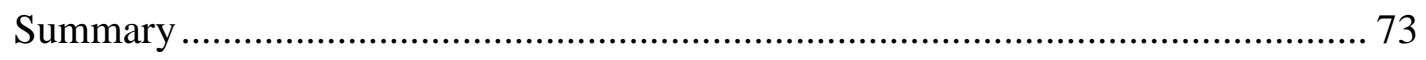

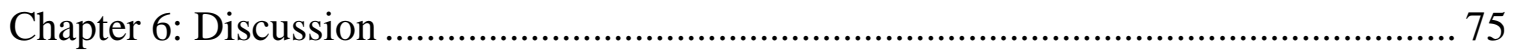

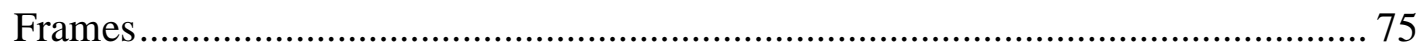

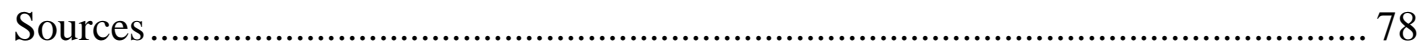

The Intersection of Frames and Sources ........................................................ 79

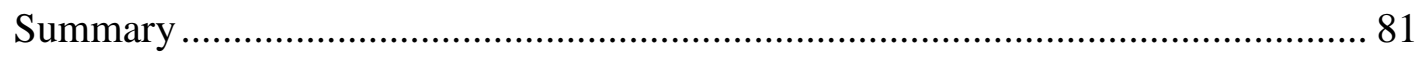

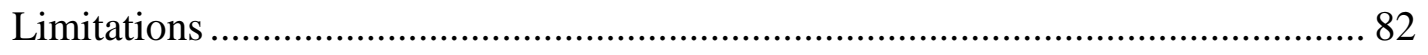

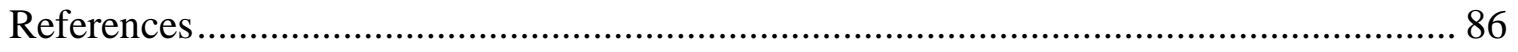

Appendix A: Comprehensive List of Sources ...................................................... 98

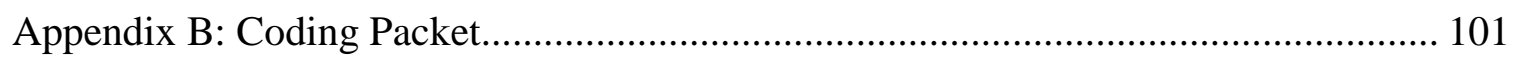

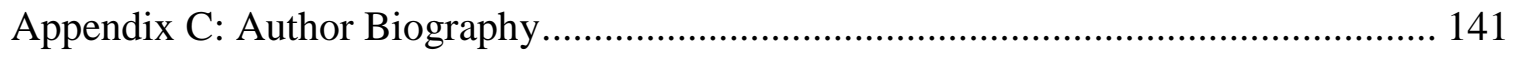




\section{LIST OF TABLES}

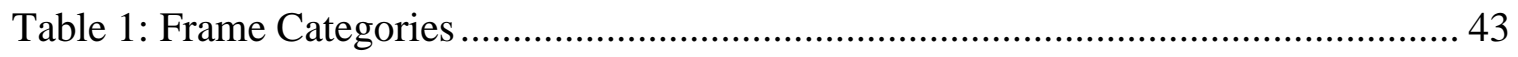

Table 2: Categories by Frequency and Percentage of all Key Events ........................... 52

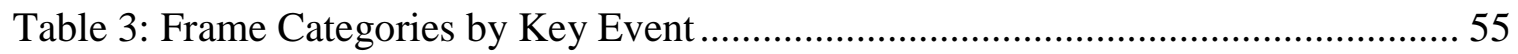

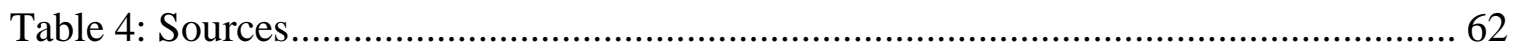




\section{LIST OF FIGURES}

Figure 1: Research Design Overview .................................................................... 23

Figure 2: Map of Online Activity of for the keywords "Henrietta Lacks"....................... 32

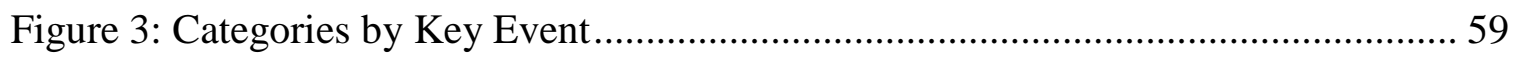

Figure 4: Source Frequency by Key Event ..................................................................... 66

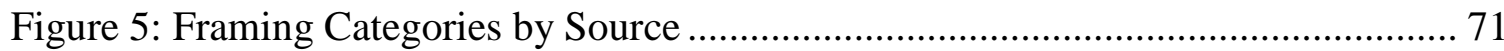




\section{PREFACE}

In many ways the internet has shaped me personally and professionally. My earliest childhood memories include the green-on-black flicker of MS-DOS. At 16, I had my first experience with image editing software. Since then, I have built websites, produced web video and developed user interfaces. My involvement in digital media engenders a technical understanding of online communication. However, my participation in the process of media production makes me consider the broader implications of my actions, as well as the collective actions of those who also work in the digital field. In a recent manifesto written by anonymous contributors from around the world, the Mozilla Foundation (the non-profit organization that developed the Firefox browser) referred to the internet as "a global public resource" (Mozilla, 2011, n.p.). If this declaration is true, then the internet is an intensely influential channel.

The ability to set the internet agenda harkens back to Donald Shaw and Maxwell McCombs' 1968 study of presidential election coverage, when they theorized that print and broadcast media have the ability to set the public agenda by the sheer quantity and placement of coverage. "In reflecting what candidates are saying during a campaign, the mass media may well determine the important issues—-that is, the media may set the 'agenda' of the campaign" (p. 176, 1972). In other words, the media influence what issues are deemed important by publics. By focusing on some issues over others, the media create an agenda of which issues are important and salient.

Scholars have studied agenda setting as a form of influence, arguing that the ability to shape an agenda is a form of power. Power stems from deciding what publics 
find important. Bernard Cohen (1963) stated: "The press may not be successful much of the time in telling people what to think, but it is stunningly successful in telling its readers what to think about" (p. 13). In other words, the media may have the ability to penetrate the cognitive processes of the audience member by tapping into assumptions, stereotypes, and lived experiences. Walter Lippmann (1922) argued that the media construct our reality; therefore to set an agenda is to define the world in which we live. This reason alone, the ability to shape reality, confers a tremendous amount of power. While defining "power" is an unwieldy task, I borrow from Michel Foucault's observation in "Power and Knowledge" (1980) that power is "spun through discourse" and that, to understand power, we should focus on the "materials" and "tactics" of power in discourse. Foucault saw media as powerful in their ability to shape an agenda that influences what issues become salient for mass publics. On a fundamental level, the power of discourse lies in the ability to influence the construction of meaning among receivers of information.

Lippmann's and Foucault's observations intersect at the construction of meaning. Foucault stated that, "power reaches into the very grain of individuals ... inserts itself into their actions and attitudes, their discourses, learning processes and everyday lives" (1980, p. 39). Lippmann echoed this sentiment; he claimed that meaning is negotiated by those in power, specifically members of the media. For example, an issue that gains traction on the internet may be more likely to influence publics compared to an issue that gains little attention. In this context, the ability to create or manufacture "salience" is arguably a form of power, according to Foucault's conceptualization of power. Using this 
logic, the ability to create salience on the internet - the ability to gain attention to a cause by ensuring it becomes the focus of media attention - enables individuals and organizations to leverage issues on the public agenda.

Methodologically speaking, Foucault suggested that social researchers concentrate on the productive effects of power, as opposed to the repressive effects (1977). Although interested in the productive qualities of power, my main objective concerns the diffusion and framing of information rather than its effects. I am particularly interested in the initial process of the diffusion of information. My interest in how and whether media have the power to influence publics has led me to examine how one particular event unfolded online, how the online coverage was constructed, and which sources (people or institutions) were associated with the frames themselves. 


\section{Chapter 1}

\section{INTRODUCTION}

The study undertaken examines how a narrative unfolded in the media following the publication of the most popular science book of 2010: The Immortal Life of Henrietta Lacks. Little empirical research has followed the unfolding of a narrative solely on the internet and the current study takes two streams of communication literature - diffusion and framing - to establish the theoretical platform. Using Everett Rogers' diffusion of innovation as the foundation, I asked how this particular book was diffused, or spread, online. After describing the ways in which information flowed online, I examined coverage to assess how information was framed. This descriptive approach may illustrate which key message frames gained traction in online coverage.

Once I identified the prevailing message frames, I examined the frame content for key sources identified as linked to the narrative, arguing that sources (like Rogers' opinion leaders) may be linked to the very act of diffusing information. By describing salient frames and key sources, we might better understand how the bestseller, The Immortal Life of Henrietta Lacks, gained such widespread coverage on the internet.

I begin with an overview of diffusion theory, followed by an introduction of framing theory and then a synthesis of these two theories. I will follow with a discussion on sources, internet, and finally, I describe the book. 


\section{Chapter 2}

\section{LITERATURE REVIEW}

\section{Diffusion}

Diffusion theory, also referred to as the diffusion of innovations, describes how an idea, product, or service spreads within a social network over time (Dearing, 2009; Rogers, 1995). Many people view diffusion solely as a process of adoption, but here I used diffusion to describe how the book, The Immortal Life of Henrietta Lacks, spread in its initial stages. I specifically looked at how potential adopters are initially exposed to a message. Therefore, the current research focused on the earliest stage of diffusion: the innovation-decision process. Rogers (1995) described this stage as:

the process through which an individual (or decision-making unit) passes from the first knowledge on an innovation to forming an attitude toward the innovation, to a decision to adopt or reject, to implementation and use of the new idea, and to confirmation of this decision. We conceptualize five main steps in the innovationdecision process: (1) knowledge (2) persuasion (3) decision (4) implementation and (5) confirmation. (p. 20)

Knowledge occurs when an individual is exposed to a message for the first time. Persuasion occurs when someone forms a positive or negative attitude toward the message. Decision occurs when an individual takes the steps toward responding to the message's call to action. Implementation occurs when the individual carries out the actions suggested by the message. Confirmation occurs when the individual seeks 
validation of her or his initial decision, and may re-adjust actions based on feedback (Rogers, 1995).

The knowledge stage of the innovation-decision process stems from when, "knowledge of an innovation, rather than the recognition of a problem or need by an organization leading to search for a solution, launches the innovation process" (Rogers, 1995, p. 423). In other words, the first stage of diffusion pertains to the general awareness

of an innovation or message. The knowledge stage is tied to framing, particularly agendasetting, because it is at this early stage where a potential adopter knows little about the message, and is reliant on the information producer to construct meaning (Dearing \& Rogers, 1996). The current research concerns the knowledge stage of the innovationdecision process: the initial exposure to a message and the strategic attempts to inform potential adopters in a network. The innovation-decision process is considered by Rogers as the "public relations" stage of diffusion. This is the stage where audiences are exposed to message frames prior to behavioral responses to the messages. The knowledge stage of the innovation-decision process describes this first contact, where communication strategy is most important. Framing is one way to set a message in motion in the earliest stage of diffusion.

\section{Framing}

To impart an understanding of one of the fundamental tenants of news production, I will describe the process of framing. First, a frame can be conceptualized as a device. By device, researchers mean a conceptual spool to help make sense of seemingly 
disparate bits of information. Nisbet and Mooney (2007) stated, "Frames organize central ideas, defining a controversy to resonate with core values and assumptions. Frames pare down complex issues by giving some aspects greater emphasis." (p. 56). In addition to being a device, frames are also structural elements. For example, Zillmann, Chen, Knobloch, and Callison (2004) stated, "[Frames] are headlines and kickers, subheads, photographs, photo captions, and leads, among others" (p. 60). Esser and D'Angelo (2003) added, "[Frames] include the headline, the lead, and the body of the story as well as patterns of quotations from sources" (p. 627). Martin (2003) stated, "Thus, when journalists frame a story, they deploy a structure to the narrative that helps the audience make sense of the events" (p. 193). Viewing a frame as a structural element implies that the presentation of information also influences interpretation. By presentation, I mean the factors external to the message such as format or placement.

Tuchman (1978) described frames somewhat differently, and focused on the as frame as both a structural element and as a cognitive device. She defined a frame as a cognitive device that turns unrecognizable events and conversations into discernable events. Tuchman implied framing devices help individuals decide how the message relates to their worldviews. In other words, Tuchman described how frames exist on a deeper level beyond a simple organization of talking points. She described a process in which frames serve as devices to give streams of experiences meaning. Like Lippmann, Tuchman was a social constructivist, and stated that the framing process "can be seen as the negotiation about the newsworthiness of an occurrence as a news event. And it 
imparts a character to that occurrence" (p. 193). Here, frames help make sense of ongoing interactions in a perceived reality.

Other researchers have focused on the ability of a frame to create salience. For example, a successful frame would be one that draws attention to the strategically constructed content. "The ability to spin a tale such that the strategist's key messages remain undiluted" is a way to affect an audience's perception of an event (Coleman, Hartley \& Kennamer, 2006, p.547). In addition, Nisbet, Brossard and Kroepsch (2003) stated that the science topics that get the most coverage in the media are often the most dramatized. Adding drama to a news frame may draw more attention to the message. Framing is also a strategy. If one understands the audience psychographics (e.g., attitudes, values, lifestyles, etc.) one can tailor the message accordingly. For example, Molotch and Lester's (1975) “mobilization of bias” links the importance of a message with its relationship to the leanings or agendas of the audience. Their "mobilization of bias" described why an oil spill in the United States in the 1970s was more of an issue for Californians than it was for the rest of the country. The minimization of national coverage was strategic in reducing public skepticism over whether there should be drilling, because local audiences were less exposed to negative discourse regarding the drilling. In other words, the selective reporting on the oil spill demonstrated how news producers can exploit the sensibilities of an audience to encourage a specific interpretation of an issue or event. 
Framing ultimately pertains to the way a story is structured and how an event is presented and interpreted, and how a story is made salient. According to Robert Entman (1993):

Framing essentially involves selection and salience. To frame is to select some aspects of a perceived reality and make them more salient in communicating text, in such a way as to promote a particular problem definition, causal interpretation, moral evaluation, and/or treatment recommendation for the item described. (p. 52) By salience Entman meant, "making a piece of information more noticeable, meaningful, or memorable to audiences" (p. 53). Assessing salience in a message as part of a broader news event "recognizes the ability of a media presentation to define a situation, to define the issues, and to set the terms of a debate" (Tankard, 2001, p. 98). In summary, frames make sense of experiences, therefore those news producers that can leverage salience have the ability to define reality.

\section{Framing and Diffusion Synthesis}

Framing and diffusion describe two different communication theories that dovetail to describe the negotiation of reality. Constructivists believe that this act of negotiation exists on a societal level and occurs through transactions of information (Lippmann, 1922; Tuchman, 1978). Recall that diffusion describes the spread of an idea or message through a social network (Rogers, 2005). Framing selects aspects of perceived reality with the intent of convincing audiences that the message is important (Entman, 1993). Framing and diffusion intersect at the salience transfer. Here, salience 
transfer describes the alignment of the audience's interpretation of a message with the objective of the information producer. This approach to salience transfer is a deeper description of the process that occurs within McCombs and Shaw's (1972) agenda-setting model. By deeper description, I mean attending to the mechanics of the salience transfer via the decision-innovation process of diffusion. In other words, exposure to a message needs to come before any decision-making process. Consequently, a decision made in response to a message affects the message's movement through a social network. In the following section I discuss research that examines this juncture of framing and diffusion.

At its completion stage, diffusion serves to bring about a behavioral response in a social network. Classic framing research on social movements often alludes to a diffusion process. For example, Snow, Rochford, Worden, and Benford (1986) examined the persuasive powers of frame tactics in social movement organizations (SMOs). Among the SMOs they examined are the Nichiren Shoshu Buddhist movement of Hare Krishna and the peace movement of the 1980s in protest of the nuclear arms race. Here, the diffusion occurs in the participatory aspects of SMOs - Snow et al., are referring to the fluid interactions between an individual and a group or organization that result in the dynamic transmission of ideas. Social movement research is implicitly diffusion research due to the focus on understanding how information moves through social networks. Social movement research also attends to the individual and organizational flow of information. For example, the prototypical "grass-roots" approach often involves individual-level communication as a way to diffuse information on a broader, organizational level. 
Though Snow et al., attended to the micro-macro salience transfer, recent research has addressed diffusion directly. For example, Chabot (2004) explored the diffusion of ideas between African-American intellectuals and Gandhian activists, specifically, the ideology that laid the groundwork for nonviolent protest during the American civil rights movement. Chabot studied how the pacifist frame entered the civil rights psyche by tracing its emergence to specific events such as Martin Luther King's four-week visit to India in 1959.

A social movement can be an ideal outcome for many communication campaigns, however not every communication strategist seeks large systemic changes; sometimes the end-goal is to simply promote a product. Put simply, one can view diffusion as the vehicle for a frame. For example, Kennedy and Fiss (2009) conducted a study on hospitals regarding the diffusion of a care management policy. Kennedy and Fiss explored how message framing affects different stages of adoption:

Specifically, we argue that early adoption is associated with opportunity framing and motivations to achieve gains, both economic and social, while later adoption is associated with threat framing and motivations to avoid losses, again in both economic and social terms. (p. 899)

In other words, Kennedy and Fiss found frames that are effective with early adopters that encourage competitiveness and efficiency; and frames effective with late adopters stem from the "don't get left behind" approach (shaming into conformity). Furthermore, "At the beginning of a diffusion process, rhetorical arguments play an important role in framing practices and establishing their legitimacy, but the prevalence and complexity of 
such arguments decline over time as innovations are institutionalized" (Kennedy \& Fiss 2009, as cited in Gamson \& Meyer, 1996; Green, 2004; See also Green, Li, \& Nohria, 2009; Suddaby \& Greenwood, 2005). Therefore, framing plays a key role in the innovation-decision process of diffusion, and declines in influence as a message or idea becomes the norm.

To summarize, frames serve to legitimize an innovation or message before it is widely accepted. Kennedy and Fiss crossed these theoretical streams to understand how organizations "think" - by highlighting micro-macro interactions "affecting the thinking of key decision makers" (p. 900). At this stage of diffusion, framing is meant to affect the decision-making processes of influential individuals within a social network. These important people have the power to incite institutional change because their decisions can trigger a series of behavioral responses among other adopters. Rogers referred to these influential individuals as opinion leaders. In the following section I will discuss the role of opinion leaders in news production.

\section{Opinion Leaders as Sources}

A conceptual cross-over exists between opinion leaders in diffusion theory and sources in news production. Rogers stated that opinion leaders have the ability to accelerate or slow the diffusion of a message within a social network because they can influence the behavior of other adopters. By focusing on opinion leaders within a social network, a communication campaign can expedite a salience transfer. On the other hand, a news source is an individual who provides information to a journalist. News sources 
often have an elevated status and are solicited for information because they possess some sort of authority on a particular news topic. Therefore, if the media have the ability to set the public agenda, then sources become agents of diffusion because they transfer salience (McCombs \& Shaw, 1972; Rogers 1995).

Opinion leaders and sources are both considered "diggers and aggregators of information" and "conduits of public opinion" (Wallsten, 2010). That is, sources have an influential status in news production: they legitimize the news much like opinion leaders legitimize adoption within a network. For example, Meraz (2011) described how sources in political blogs are a part of a two-step flow process; news flowed from sources to the followers of the blogs. She found two trends: "the growing power of social influence among partisan blog networks and the weakening influence of elite, traditional media as a singular power in influencing issue interpretation within networked political environments" (p. 88). In other words, Meraz's study showed how status boundaries were blurred between informal opinion leaders in social networks and sources in institutionalized media. I argue that these two roles possess a similar function that transcends authority conferred by institutionalized media; as sources and opinion leaders are both vectors of news, they carry and transmit information throughout social networks.

At times, the presence of a source has an effect on diffusion by influencing the way the information is framed. For example, Coleman et al. (2006) found that:

Scholars concur that sources equipped with the resources to manage information are those most successful in getting their voices heard and who thus "set the 
frame" in discourse. Source use is therefore a key feature in framing and is intimately tied to issue definition. (p. 547)

Coleman et al. stated that the presence of a source has an effect on the frame, and the presence of a source helps frame public discourse. Foucault (1980) argued that power structures are evident at every level of society. If we look at power as the ability to set salience, then opinion leaders are localized versions of news sources. In other words, opinion leaders manifest in many ways, depending on the micro-macro nature of the social network: internet message boards, talk show hosts, or well-known cancer researchers. Therefore, any of these types of individuals or organizations have the ability to set the public agenda; an area no longer the exclusive purview media-endorsed sources.

Now, a source can be any person or organization quoted, linked to, or somehow attributed within the news content. Applying this concept to the internet communication, links and source mentions are two ways to identify potential opinion leaders. By links I mean content attributions (for example: an internet opinion piece that has a link to the original news article that elicited the response) or further information within the content originating elsewhere. For example, Kleinberg (1999) stated that links confer authority, and Davenport and Cronin (2000) stated that links suggest trust and the desire are affiliated with the source. Examining how opinion leaders accelerate frames in the innovation-decision process of diffusion reveals the dynamic, ongoing negotiation of salience in internet communication. 


\section{Internet Communication}

Internet communication is a hybrid model in a micro-macro sense of communication because producers and consumers are the same group, facilitating both interpersonal and mass communication (Levinson, 2009). Flanagin, Flanagin and Flanagin (2009) described the internet as a technological artifact because of the communal factor: "Technological artifacts thus result from a complex interaction between technical capabilities and the interests and values of many individuals, groups, and organizations" (p. 2). Most importantly, Flanagin et al. stated, "Among other things, this shift toward greater individual interconnectivity, personalization, and innovation has upset traditional one-to-many models of mass communication" (p. 8). Therefore, due to its decentralized nature, some argue that the internet has enabled grassroots groups to mobilize messages in a more effective manner than any other form of media (Earl, 2006). This harkens back to the discussion on how diffusion and framing work together to launch social movements. The internet provides a vast channel for accelerated diffusion and a hyper-editorializing of messages (accelerated framing).

Three common conceptualizations that account for both micro and macrosocial interpersonal and mass communication - are social network analysis, Habermas' public sphere and diffusion. Two major approaches to social network analysis include connectivist and structuralist (Postill, 2008). A connectivist approach is relationshipbased, and examines the relational distance between each individual in a social network. A structuralist approach moves beyond individual relationships and looks at the parameters or settings in which interactions occur. Since the internet is such a large 
environment with an enormous amount of interaction occurring at any given time, Postill (2008) suggested that the structuralist approach is better at explaining the manner in which information travels online.

An example of the structuralist approach is field theory. Field theory is an analytical framework that examines the power structures of news institutions, with a focus on influence (Benson, 2006). Field theory weaves together the cultural and political factors that influence the manner in which an idea is adopted in a social network. Field theory also places a special emphasis on "taste makers," a concept akin to Rogers' opinion leaders.

Field theory aims to describe the setting of micro-macro communication. Another approach to understanding this type of communication is the public sphere concept (Habermas, 1962). A public sphere is a space where individuals and groups come together to discuss matters that are important to them. It serves as a forum for salience transfer on a micro level, where peers discuss ideas and grievances with one another. Habermas recalled a time when the bourgeoisie of the $19^{\text {th }}$ century congregated to engage in discourse and civil action, what was referred to as "salon" meetings. Habermas speculated that the mass media dissolved the public sphere because information became widely available during the industrial revolution. Simply put, the industrial revolution gave way to institutionalized media, the birth of the modern news business. He argued that the all-encompassing presence of the media killed micro-level discourse about salient issues in the public sphere. The analogy to Habermas' public sphere helps researchers understand the discourse that occurs on the internet, as opposed to a structural analysis or 
field theory (Carey, 1995; Fraser, 1992; Papacharissi, 2009; Postill, 2008; Putnam, 1996; and Schudson, 1997).

Some researchers argue that the internet is the rebirth of Habermas' public sphere because it dramatically altered the private and public spheres by creating a "third place" (Jacobs, 1961; Schuler, 2004). To clarify, urban renewal activist Jane Jacobs (1961) argued for the revival "the third place," a social space apart from home and work. However, those who argue for the rebirth of the public sphere hold that the internet provides the "salon" (a hosted gathering for the purposes of entertainment or education through conversation) equivalent to modern society (Postill, 2008). I argue that this "third place" or "salon" is often housed in social media platforms. Social media, a type of internet communication, loosely resembles a public sphere based on Habermas' criteria, because it is strongly interpersonal yet public at the same time (Levinson, 2009). Conceptualizing the internet as a "place" implies social and cultural associations as opposed to viewing the internet solely as a technical innovation. Online cultural factors provide a linkage to the constructivist underpinnings of news production (Lippmann, 1922). In this sense, both the internet and the media are social products, windows into the processes of how information spreads through a society (Freeman \& Webster, 1994; Stromer-Galley \& Martey, 2009).

A major challenge for researchers is to understand the simultaneously interpersonal and public type of communication that occurs online. For the past twenty years, researchers have sought to describe the dual nature of this type of communication. I argue that applying framing and diffusion to the digital platform will facilitate a better 
understanding how information spreads. However in order to feasibly undertake an inquiry such as this, it is best to look at these factors through a specific context.

For the current research, I hope to better understand the connection between micro and macro level communication, by using case study methodology, as I explain in the next chapter.

\section{The Immortal Life of Henrietta Lacks}

The focus of the current case study is The Immortal Life of Henrietta Lacks, written by Rebecca Skloot. The book was released on February 2, 2010, and immediately became an Amazon bestseller (Kellogg, 2010). Skloot first learned of HeLa cells in 1988 in a high school science class. Her teacher wrote the words "Henrietta Lacks" on the board and explained to the class the origin of the first human cell line came from a black woman. Skloot talked to her teacher after class, and he told her that no one really knew anything about Henrietta Lacks. At that moment, Skloot's journey began: to tell the story about the woman behind the "HeLa cell." The book took more than 10 years for Skloot to write and was partially funded by student loans. Skloot spent a number of years trying to contact the Lacks family. The family was reluctant and wary because of interactions with a swindler promising reparations for their mother's death and a scientist soliciting blood samples under dubious circumstances. Skloot eventually became trusted by the family, after much persuading.

Despite multiple edits and rejection from publishing houses, Skloot finally found a home for Henrietta Lacks' story at Crown Publishing. The biography came together as 
a narrative with three distinct stories; the story of Henrietta Lacks; the story of her children (their experiences with the author); and the story of the science, circumstances and individuals behind the innovation of the HeLa cell.

The book begins with a description of Henrietta Lacks' childhood in rural Virginia on a tobacco farm in the 1920s. Henrietta grew up in a "home house" with relatives and was raised in the same room as her future husband (and first cousin) Day, or David. Henrietta had her first child with David at age fourteen. They later married. After the birth of her fifth child, Henrietta felt a "knot" inside her. She received care in a "colored" ward at Johns Hopkins, a hospital in Baltimore, Maryland. As was customary at the time, doctors would take tissue samples without disclosing their intent or seeking consent. A doctor removed some of Henrietta's cervix for a cell culture. It was later determined that Henrietta had an aggressive form of human papillomavirus (HPV), which led to the cancer that killed her in a matter of months after her initial diagnosis. A key factor in the controversy is that Henrietta Lacks did not know her cells we removed from her body, and her family members did not learn of the multi-billion dollar industry that resulted from the culture until twenty years after Lacks' death.

Skloot takes the reader on a journey, describing the experiences of Henrietta's children and the scientific innovations that came from her cells. HeLa cells became significant because the cells stayed alive outside of the body, unlike any other human cell culture up to that point. The cells multiplied and HeLa cells became the "white mice" of cancer studies. In addition, HeLa cells have had a significant role in the development of 
the polio vaccine, HIV/AIDS research, as well as technologies such as in-vitro fertilization and the Pap smear.

Controversy surrounds the autobiographical account of Henrietta Lacks, especially evident in a chapter called "Night Doctors." In this chapter, Skloot provides a brief history of the distrust African Americans have for the white medical establishment stemming from the time of slavery in the United States. Exploitive themes in the context of biological assets such as cell lines have been examined by both scientists and critical scholars alike (Appadurai, 1986; Lock, 2001; Thomas \& Crouse Quinn, 2000).

Another theme in the The Immortal Life of Henrietta Lacks is the comparison to the Tuskegee studies. For example, Skloot (2010a) wrote, "Black scientists and technicians... used cells from a black woman to help save the lives of millions of Americans... And they did so on the same campus - and at the very same time - that state officials were conducting the infamous Tuskegee syphilis studies" (p. 97). To briefly summarize the Tuskegee experiments, from 1932 to 1972 the U.S. Public Health Service (PHS) conducted a study officially titled, "Tuskegee Study of Untreated Syphilis in the Negro Male" on 600 black men (399 with syphilis and a control group of 201) in Macon County, Alabama (Thomas \& Crouse Quinn, 2000). The men were never told they had syphilis and were subjected to spinal taps and other procedures without treatment for the disease. In the study, the "end point" was the subject's autopsy. The family was given up to fifty dollars in burial reparations.

The Tuskegee Study has far-reaching implications that affect health policy even at present. The "Night Doctor" chapter in Skloot's book relates the abuses alleged at 
"colored" wards at hospitals such as Johns Hopkins and events such as the Tuskegee study, which have seared distrust of the white medical establishment into the collective memory of African-Americans ${ }^{1}$ (Lock, 2001; Skloot, 2010a; Thomas \& Crouse Quinn, 2000).

In the context of the Tuskegee study, collective memory has had an effect on contemporary public health because the racial folklore has been passed down to the descendents, making issues such as the HIV/AIDS containment in African American communities difficult. Some individuals are afraid to seek treatment because of intergenerational distrust of the medical establishment due to a sordid history of abuse and exploitation (Thomas \& Crouse Quinn, 2000).

Access to health care is another prominent theme in The Immortal Life of Henrietta Lacks. Henrietta sought medical attention at Johns Hopkins because the institution provided services for the poor (Skloot, 2010a). The subjects in the Tuskegee experiments consented to the study because in Alabama they were lured with the promise of free health care (Thomas \& Crouse Quinn, 2000). Skloot succinctly illustrates this theme by reminding the reader that Lacks' surviving children do not have access to healthcare, despite the contributions their mother made to science.

Questions of policy and legal definitions also arise. One example discussed in the book was when a doctor (David Golde) sold his patient's (John Moore) spleen because he had a rare form of cancer and labs were bidding for this unique specimen (Skloot, 2010a). Moore sued Golde, but Moore lost the lawsuit and Golde was able to keep the profits

\footnotetext{
${ }^{1}$ Collective memory refers to group memory often passed on orally and communally constructed (Halbwachs, 1992).
} 
from the sale. However, Golde's medical license was suspended because he did not disclose his intent to his patient. Lock (2001), a social historian, addressed the vast array of ownership issues exhibited in The Immortal Life of Henrietta Lacks:

Who "owns" genetic material? Individuals? Communities or tribal groups? Corporate organizations? Or humankind? Representatives of indigenous groups for the most part exhibit a preference for group ownership (Shelton, 1998), whereas US property law upholds individual ownership provided that body parts are not separated from the body in question. Other people argue that DNA cannot belong to anyone, or, alternatively, that it belongs to us all, and yet others claim that ownership through the patenting of body tissues and cells is essential if scientific research is to remain competitive (p. 86).

The Immortal Life of Henrietta Lacks has gained traction with lay publics as the first extensive biographical account of the origin of the HeLa cell line. Other work has been published on Henrietta Lacks, but not in this depth (see Curtis, 1997; Davidson, 1954; Jones, McKusick, Harper, \& Wuu, 1971; Rogers, 1976; as cited in Skloot, 2010a). In summary, the social discourse surrounding HeLa cells touches the public's most fragile of sensibilities, such as ownership of bodies, the treatment of minority groups by scientific institutions, and the judgments made in defense of progress. The most intriguing aspect of this case is how one single individual changed modern medicine. The cells taken from her body impacted almost every human being who has sought health care since the 1950s (Kellogg, 2010; Skloot, 2010a). 


\section{Chapter 3}

\section{RESEARCH QUESTIONS}

To better understand how The Immortal Life of Henrietta Lacks spread in the initial stages of its publicity campaign, I present research questions that attend to the process of influence in online social networks. In other words, the current research is guided by questions that focus on frames, sources and the intersection of frames and sources. Observing how information is shared, and who is involved, harkens back to Foucault's (1980) emphasis on the "materials" and "tactics" of power in discourse.

Specifically, I'd like to examine how and if sources and frames can influence the way online audiences construct meaning (the salience transfer) and therefore, shape the public agenda. For the purposes of clarity, I will present the research questions to provide context for the case study. In the next chapter, Methodology, I will describe the ways that I measured (operationalized) these concepts. The research questions are:

Research Question 1: How was The Immortal life of Henrietta Lacks diffused online?

By "diffused" I mean how the amount of online coverage spread during the initial communication stage (Rogers, 1995). By "online coverage" I borrow the definition from Price, Tewsksbury and Powers (1997): "issues, events, and people deemed newsworthy and thus deserving of media attention" (p. 482). By “media attention," I mean stories, notes and mentions that occur on the internet and are widely accessible. 
Research Question 2a: What emergent frames are associated with online diffusion of The Immortal life of Henrietta Lacks?

By "frames" I borrow from the literature. I define frames by applying Tankard's definition as "salient aspects of content" (2001). By "salient" I mean content made "more noticeable, meaningful, or memorable to audiences" (Entman, 1993, p. 53). By emergent frames, I mean frames that are revealed in the online content, and are not established in advance (Russell, 2009).

Research Question 2b: Do any discernable patterns describe the frequency of frames that emerged in the online diffusion of The Immortal life of Henrietta Lacks?

By "discernable patterns" I mean peaks, ebbs and flurries in the activity related to clusters of "online coverage" (Tewksbury \& Powers, 1997).

Research Question 3a: Which sources are associated with online diffusion of The Immortal Life of Henrietta Lacks?

By "sources," I mean any individual mentioned or identified in the "online coverage" Recall that I earlier discussed that a "source" is similar to an "opinion leader" in that they 
are both transmitters of information (Coleman et al., 2006; Davenport \& Cronin, 2000;

Kleinberg, 1999; McCombs \& Shaw, 1972; Meraz, 2011; Rogers, 2005; Wallsten, 2010).

Research Question 3b: Do any discernable patterns describe the frequency of sources that emerged in the online diffusion of The Immortal life of Henrietta Lacks?

Once again, by "discernable patterns" I mean peaks, ebbs and flurries in the activity related to the use of sources in online coverage (Tewsksbury \& Powers, 1997).

Research Question 4: Do source patterns have any association with frame patterns observed in the diffusion of the Immortal Life of Henrietta Lacks?

By examining the relationships between source and frame, I can link together framing and diffusion literature. That is, I can see what role opinion leaders within a social network have on a salience transfer. To return to the literature, sources have the ability to frame messages that create media agendas. Therefore, if the media have the ability to set the public agenda, then sources become agents of diffusion because they transfer salience (McCombs \& Shaw, 1972; Rogers 2005). 
Figure 1.

Research Design Overview

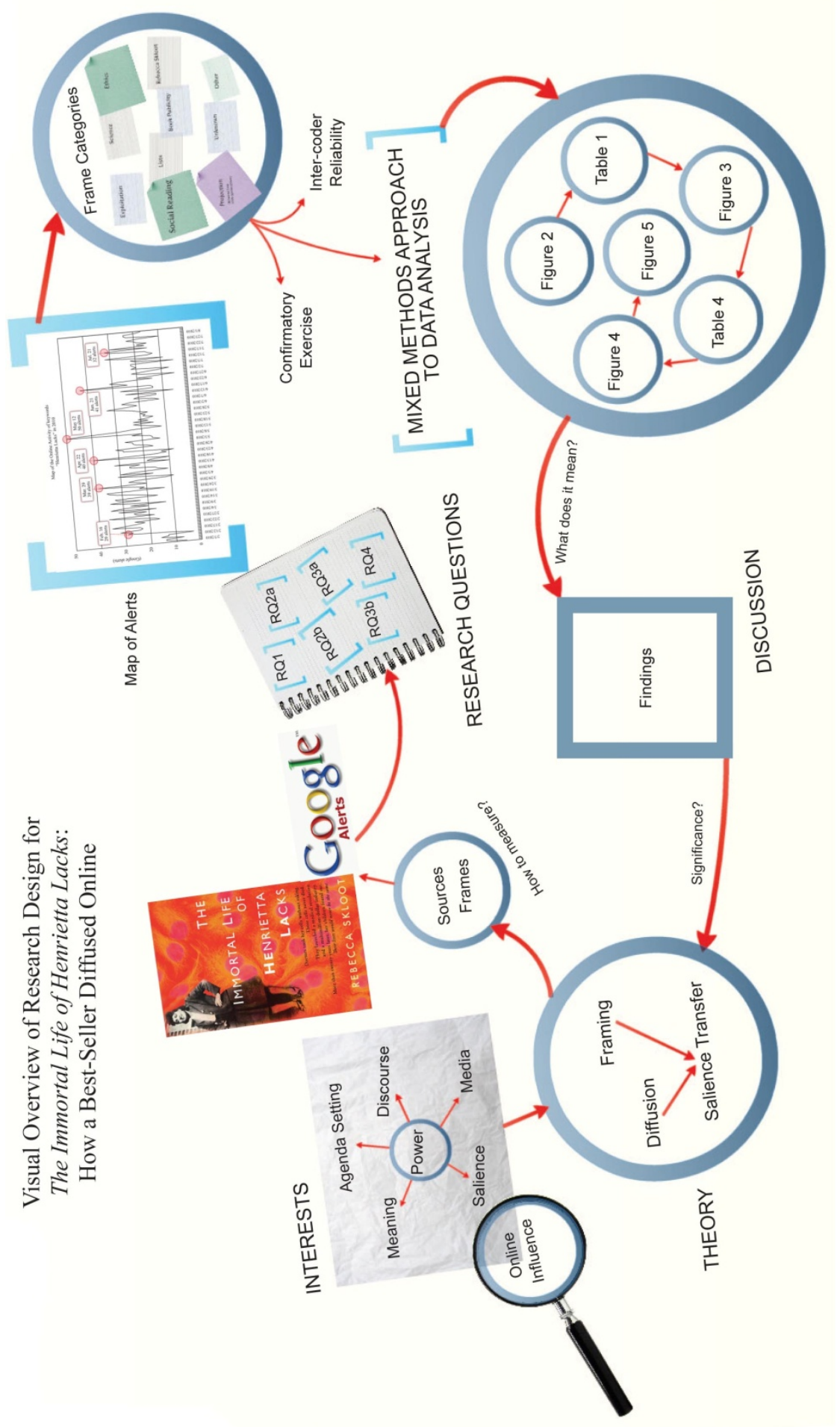




\section{Chapter 4}

\section{METHODOLOGY}

The research questions are designed to explore how The Immortal Life of Henrietta Lacks spread online. To address these questions, the current research used a mixed-methods approach with several stages in a five-step methodology. The first three steps are common in deductive methods. The next two steps follow a more inductive approach, as noted below.

Briefly, the first three steps were conducted as follows: 1) Collect data of the online coverage surrounding The Immortal Life of Henrietta Lacks; 2) Plot the data on an $\mathrm{x}$ and $\mathrm{y}$ axis to visually describe the book release over time while isolating key points in the data (such as noticeable peaks in activity); and 3) Develop criteria for framing and source analysis.

The third step includes the following: a) Extract a statistically significant sample from the population of online coverage; b) Perform a close reading of the online coverage culled from the sampling procedure; and c) Identify the emergent frames within the online coverage and place them in conceptually congruent categories.

Once equipped with the tools and categories developed above, I analyzed the data using a mixed-methods approach which will be discussed in detail below. A brief summary of the steps pertaining to the initial stages of analysis follows: 4) Perform a close reading of the content in the key data points (identified in step 2 above) while recording the dominant (mutually exclusive) frame category for all online coverage in 
these zones of significant activity and finally, 5) observe and count any (manifest) mentions of sources.

\section{Case Study Methods}

As already noted, the current study employed a five-step analytical process recommended in case study methodology, which employs a mixed-methods approach. The methodological framework articulated by Robert Yin (2009), states that uniqueness is imperative in a single-case study. The Immortal Life of Henrietta Lacks is unique for three reasons. There is only one Henrietta Lacks: the woman who died of cervical cancer in 1951 whose cells resulted in the first "immortal" human cell line. The Immortal Life of Henrietta Lacks is the only biographical account that features both historic accounts of scientists and the Lacks family. Rebecca Skloot's innovative use of social media propelled the book to an Amazon bestseller immediately upon its release (Kellogg, 2010). Another reason for the case study methodology relates to the communication channel: the internet is a very large space to manipulate variables pertaining to the dissemination of a popular book. Therefore, selecting an exemplar was necessary. In the following section I will describe my research questions in greater detail and discuss how they fit in the context of the methodological process.

\section{Operationalizations}

To begin, I examined the patterns of online coverage following the release of a popular book. The patterns of coverage described how The Immortal Life of Henrietta 
Lacks spread. Recall the first research question: How is The Immortal life of Henrietta Lacks diffused online? For the current study, diffusion is applied to the early stages of an innovation's introduction to a social network: the knowledge stage of the innovationdecision process (Rogers 1995). Recall, by “diffusion" I mean how the amount of online coverage spread during the initial communication stage (Rogers, 1995). By “online coverage" I borrow the definition from Price, Tewsksbury and Powers (1997): "issues, events, and people deemed newsworthy and thus deserving of media attention" (p. 482). By "media attention," I mean stories, notes and mentions that occur on the internet and are widely accessible.

In order to obtain online coverage I utilized a web service, Google Alerts, which captured the principal unit of analysis in the study, a "content item." A content item refers to the information gathered by a Google Alert ${ }^{2}$ for the keywords "Henrietta Lacks." Other scholars have used this method of analysis. Ackland, Gibson, Lusoli, and Ward (2010) used a tool similar to Google Alerts and compared commercial web sites, with social web sites seeking keywords that referenced attitudes toward nanotechnology. Ungar (2008) utilized Google alerts to follow how the media cover the bird flu pandemic, gathering data from April 2004 to March 2006. Ungar argued that Google Alerts generated a population of English-language content on the bird flu, and therefore provided a "unique global perspective on an issue with worldwide reach and ramifications" (p. 473). Such a method is similar to the approach taken by researchers

\footnotetext{
${ }^{2}$ This study is using Google Alerts instead of Yahoo Alerts because my pilot test found that that Yahoo alerts were too cumbersome; the alerts were not chronologically organized, but bundled and based on items that had not been clicked.
} 
who have examined diffusion of information, one key underpinning of the current research. To summarize, "online coverage" is information recovered by Google Alerts. "Online coverage" is a general term for "content items," the principle unit of analysis in the current case study. "Media attention" will be measured by points of increased online coverage, and specific parameters are unspecified at this juncture due to the emergent nature of the current study (Strauss \& Corbin, 1990).

The next four research questions involve looking deeply at the data through mixed-methods analysis. Recall Research Question 2a: What emergent frames are associated with diffusion of The Immortal life of Henrietta Lacks? By "frames" I borrow from Tankard's definition as "salient aspects of content" (2001). By "salient" I mean content made "more noticeable, meaningful, or memorable to audiences" (Entman, 1993, p. 53). More specifically, by "emergent frames" I mean frames that arise when I examined the coverage, borrowing from Russell's study (2009).

In order to determine what frames emerged, I needed to read every page (content item) and describe the content item. This process is detailed under the subheading Step Three: Develop criteria for content analysis. Recall the research question $2 \mathrm{~b}$ : Do any discernable patterns describe the frequency of frames that emerged in the online diffusion of The Immortal life of Henrietta Lacks? By "discernable patterns" I mean peaks, ebbs and flurries in the activity related to the "content items." Discernable patterns were not predetermined before the current study, but data points with unusually high "media coverage" were referred as "key events" - which are clusters of "content items" on a given day. This process is detailed under the subheading Step Two: Plotting the data. 
In order to determine "frequency of frames" I first needed to determine frame characteristics and thus answer Research Question 2a. Once I was able to describe the emergent frames, I could create groupings (categories) followed by any particular pattern in the diffusion of the online coverage. Details of the process are explained under the subheading Step Three: Develop criteria for content analysis.

Recall Research Question 3a: Which sources are associated with online diffusion of The Immortal Life of Henrietta Lacks? By “sources," I mean any individual mentioned or identified in the "content item." Recall that I earlier discussed that a "source" is similar to an "opinion leader" in that they are both transmitters of information. One way to determine an opinion leader in the media context is to look at the sources involved in a story. Recall that researchers frequently assert that sources affect the frame content, and hence, public discourse. (See, for example, Coleman et al., 2006). By “sources," I mean any individual mentioned or identified in the "content item." Research Question 3b: Do any discernable patterns describe the frequency of sources that emerged in the online diffusion of The Immortal life of Henrietta Lacks? As with the research questions pertaining to frames, here, by "discernable patterns" I mean peaks, ebbs and flurries in the activity related to the "content items."

Research Question 4: Do source patterns have any association to frame patterns observed in the diffusion of The Immortal Life of Henrietta Lacks?, seeks to link the frame and source observations together to better understand what role opinion leaders within a social network have on a salience transfer. This final research question utilizes all of the operationalized definitions mentioned in prior research questions. 


\section{Procedure}

Since the case study methodology is emergent in nature, I first needed to examine the data in order to attend to the research questions. In the following section I will explain this process, specifically focusing on how Google affected the research design. I also describe the "close reading" process. I will conclude with a description of the categorization of frames and sources.

\section{À Priori Process}

Step One: Data Collection. In the first week of February 2010, I signed up to receive stories about a new book, The Immortal Life of Henrietta Lacks at the Google Alert website (www.google.com/alerts). I specified that I would like to receive content for the words "Henrietta Lacks." To clarify, "Henrietta Lacks" serve as keywords. A keyword specification helps search engines sift for content based on the presence of those particular words.

I chose to receive news, blogs, and web (the "everything" option). Under the "how often" option I specified "as-it-happens" as opposed to "once a day" and "once a week." For the volume option, I chose "all results." I then submitted my email address and clicked the "create alert" button.

My first alerts began to trickle in shortly after, and I continued to receive alerts on a daily basis, sometimes several times a day. I then tallied the population of Google Alerts for the phrase "Henrietta Lacks" over the course of 180 days, from February 7 to August 5, 2010. The time frame thus begins five days after the release of the book and 
ends six months after. This time frame was chosen to generate enough data to evaluate the initial stages of diffusion. In the current study, the time frame yielded 3,838 content items from the Google Alerts. My next step was to see how the nearly four thousand content items diffused online.

Step Two: Plotting the data. To visualize the diffusion process, I created a graph of all 3,838 items over time. Other researchers used similar approaches to discern meaningful information (Arsenault, Smith, \& Beauchamp, 2006; Grady, 2006; Lynch 2006). Arsenault et al. used Latour's graphism theory, which holds that visual representations of information, such as graphics, are central to scientific comprehension. For example, Arsenault et al. (2006) stated, "those who study the role of visual representations in science note that images can convey highly complex information that is not readily conveyed in linguistic symbols" (p. 39). Social researchers use graphs and other types of data visualization because the forms are immutable, they convert ephemeral observations into tangible presentations, and they feed the need for pattern recognition to create meaningful interpretations. Lynch (2006) placed value in scientific images because they depict that which is too large, too small, too fast or too slow to directly observe. In the current research, the activity map helped display a concept too large $(3,838$ web pages over the course of 180 days) to conceptualize without a visual aid. I will later discuss how data visualization plays a key role in reporting results.

Therefore, the data visualization elucidated discernable patterns of media coverage making clusters of "content items" - "key events" - apparent. The rationale behind graphing activity is to provide a picture of diffusion and address my research 
questions. Each Google Alert retrieved anywhere from one to twelve content items. A more detailed discussion on content items within alerts can be found under the Step Three: Develop criteria for content analysis. (See Figure 2.) 
Figure 2.

Map of Online Activity of for the keywords "Henrietta Lacks" in 2010

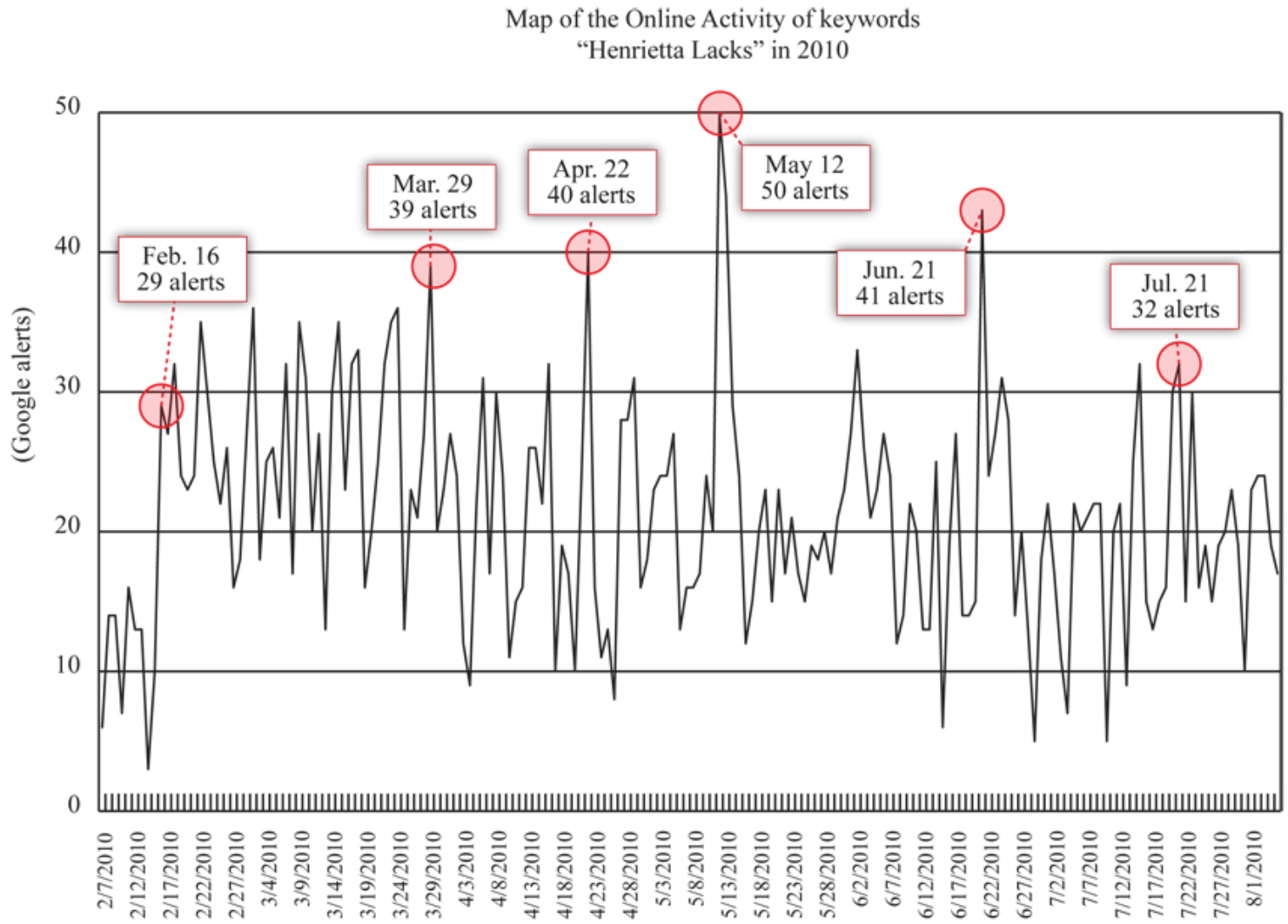

Activity was determined by the key words "Henrietta Lacks." The dependent variable on the vertical axis is the number of Google alerts received, the independent variable on the horizontal axis is the day in the data set. Total number of alerts is 3,383 .

When I charted the items (see Figure 2), four spikes appeared as the highest data points: March 29 (39 alerts); April 22 (40 alerts); May 12 (50 alerts); and June 21 (41 alerts). Another noticeable feature of the data was the first spike, which occurred February 16 (29 alerts) signaling a jump of activity after February 14, (3 alerts). Although February 16 was not a day of high indexing, it was included in the analysis because it was the first spike in the activity. For the purposes of symmetry, I also selected the last spike 
in coverage in the 180-day period. I chose July 21 (32 alerts) as an end point. This day represents the last peak of activity across the 180-day period. Therefore, I refer to these six spikes of coverage as key events. By isolating key data points, I could examine the high points of online activity. Recall that data points with unusually high media coverage are referred to as "key events." I counted all of the content items captured within each alert that fell on a key event date, resulting in a total of 231 content items.

Step Three: Develop criteria for content analysis. Recall that a key variable in the study is the frame, which I defined as attributes of content that are salient (i.e., noticeable, meaningful, or memorable.) In order to investigate how The Immortal Life of Henrietta Lacks was framed online, my intent was to determine frame categories for evaluation, much like Russell (2009) and Ungar (2008). A sampling procedure was then employed to lay the foundation for a coding process. In order to create categories, I needed to understand the characteristics of the content in order to determine "frames." I therefore selected a sample of frames to use for determining categories. My process followed these steps: I used a statistical significance calculator that indicated that 349 content items (web pages), extracted randomly, would give me a 95\% confidence level and a margin of error of 5 (recall that I had 3,838 content items). I then used a random number generator to select the sample. In Microsoft Excel, the alerts were numbered from 1-180 to represent the days in the data. I used this numbering system as a point of reference for the range generated by the randomizer. Since anywhere from one to twelve content items could be found within one Google alert, I repeated the process until I 
reached 349 content items. Once I obtained the sample, I read the 349 content items to identify emergent frames in online coverage of The Immortal Life of Henrietta Lacks.

Categories. Following Russell (2009), I determined frames by a close reading of the content items. In other words; discerning frame content is a form of textual analysis. Culler (1997) noted that a close reading is to treat a work as something of interest in itself, rather than a "symptom" of something else by interpreting a cultural object as complex structure. Culler addressed interpretation as a process: "For any element of work, you can ask what it does, how it relates to other elements, but interpretation may ultimately involve playing the 'about' game: 'so what is this really about?"' (p. 64). Other researchers have used close readings to measure frames, for example, Coleman and Dysart (2005) followed Culler's lead, and “examined news coverage using a 'close reading' of all news articles that met the search parameters in the study. Our intent was to gain insight into the tenor of the news coverage, noting particular frames that emerged and assessing how scientific rationality and cultural rationality took shape" (p. 236). Coleman and Dysart measured emergent frames by key words and recurring themes. Russell (2009) conducted a study on fictional representation of science in British novels from the 1930s and the 1960s. He used the close reading method to determine "doing science" frames and the "ethical implications of science" frames.

My sample of 349 content items yielded a diverse array of frames. Among those that emerged were: Frankenstein comparisons; exploitation; racism; family; writer's resources (how to write non-fiction); detective mysteries; "HeLa as a heroine"; reproductive health; Black history month; genetic ownership; conspiracy theories and 
more. I created an overall list of frames based on the close reading. However, in order to see patterns of frames across time, I needed to organize these emergent frames into categories.

To determine categories, I observed similarities in which the substantive topics were discussed. Categories were created to serve as groupings for conceptually congruent frames. I then grouped all frames into eight categories as follows: 1) the exploitation category which mainly pertained to the Lacks' family misfortune and racial discussions; 2) the science category which pertained to medical and technical discussions regarding the HeLa cells, especially cancer and HPV research; 3) the ethics category which pertained to the macro or policy issues surrounding topics in the book, such as genetic ownership; 4) the anthropomorphism category was designated for contemplative or imaginative discussions regarding the book (later renamed projection); 5) the lists category consisted of items structured as listings, either retail or top-seller lists, etc; 6) the book publicity category which pertained to the release of The Immortal Life of Henrietta Lacks, 7) the Skloot category which pertained to content focusing on the author; and 8) the social reading which pertained to information about the people reading the book. I arrived at the categories by placing common frames into collapsed categories representative of overarching concepts. To further explain, I will provide an example from each category. I came upon a story written by Cynthia Littleton for Variety (2010). The article was titled, “Ball, Winfrey partner on 'Life': Pair will produce HBO pic via Harpo." The article announced the partnership of Oprah Winfrey, Alan Ball and HBO Films to create a Henrietta Lacks movie. Two photos are to the right of the content, one 
of Oprah Winfrey and one of Alan Ball. The content reads: "Book blends the story of the groundbreaking science enabled by Lack's (sic) unusual resilient cells with the devastation that her death and the medical research process had on her family" (n.p.). Overt emphasis on the hardships of the Lacks family, and how they suffered at the hands of science, appeared to me as belonging to an exploitation category.

Another frame category can be found in a feature article written for the Guardian newspaper (UK). Science writer, Liz Hunt, wrote a piece titled: "The Immortal Life of Henrietta Lacks: a bittersweet legacy." The content starts with a large photo of an ambertinged, microscopic image of cells. The caption reads: "Researchers experiment on human cells. The HeLa strain of cells revolutionised medical science, but Henrietta Lacks' own story was a sad one." Hunt begins recalling her experience with HeLa innovations: describing her days as a pharmacist and when she saw Adam Curtis's The Way of the Flesh (a BBC documentary). Hunt then writes a technical description of immortal cell lines. Therefore, I placed this item in the science category.

An example of a content unit that indicated an ethics frame came from a blog called Scope, published by the Stanford School of Medicine (2010). The content began with an update, Skoot's response to the post via Twitter:

Update 04/23/10: Last night Rebecca Skloot sent a tweet to @ sumedicine about our post: Henrietta's case is different in many ways, but the research done on her children's samples w/out consent? Not so different.

The tweet responded to a summary of the legal settlement between Arizona State University and the Havasupai Indian tribe. Arizona State University paid the tribe 
$\$ 700,000$ in damages stemming from a diabetes study in the 1990s. The university collected blood samples from over 200 tribal members and, "conducted additional research that the tribe contended violated informed consent" (Costello, 2010, n.p.). The blogger (Paul Costello) then wondered whether the children of Henrietta Lacks would benefit from such restitution. Costello sought the opinion of a lawyer, Hank Greely (law professor and director of the Center for Law and Biosciences) who discussed the differences between the Henrietta Lacks situation and the how the Havasupai blood samples were handled. Costello adds:

Greely does think the Havasupai case is a "big deal." At least, he hopes it will be, "because I think science has been taking a too cavalier view of how broadly it can use samples and data it gets from people for one purpose." (n.p.)

The piece closes with Costello presuming a moral victory for Henrietta Lacks based on the outcome of the Arizona State versus the Havasupi Indian Tribe. The content emphasized professional practice, informed consent, Health Insurance Portability and Accountability Act (HIPPA) and health care reform. Overall, genetic ownership is the salient theme in the blog post; therefore I placed the item into an "ethics" category.

There were several instances in the à priori sample where content items consisted of individuals projecting their personal values on the HeLa cell discourse. This type of content also took on mythical comparisons such as "Frankenstein" and other times implied a sense of agency to the cells. I called this category anthropomorphism suggesting that users where applying human-like qualities to the HeLa cells. [Note: in a confirmatory exercise (which I will detail later in this section) the participants suggested 
that this category be renamed to reflect a different area. Upon further discussion, this category was renamed projection].

To further clarify, two examples of the projection (anthropomorphism) category follow. An individual named Chase Kyla Hunter wrote a post regarding Henrietta Lacks on disclose.tv (2010). Disclose.tv purports to "revealing the truth" by providing a forum for alternative news, unexplained phenomena and paranormal activity (2011). In a post titled: "God's Final Judgment of Mankind," Hunter uses analogies such as Frankenstein to describe medical innovations. She described how scientists have created microscopic cyborgs made of human cells, and they survived when they were injected into HeLa cells during an experiment. She also refers to Henrietta Lacks as a "poor, cancer-stricken woman." The religious undertones and mythical analogies to "Frankenstein science" qualified this content for the anthropomorphism category (later renamed projection).

A second example occurred on a website for "Ramtha's School of Enlightenment" (2010). An individual name Jaime Leal-Anaya posted a discussion on Henrietta Lacks, which resulted in an optimistic discussion on cancer:

But what is a cancer cell? It is an outbreak, a revolution. It accesses its own genius. It becomes immortal and convinces all the other cells around it to become immortal. They then start to march and play war on every other cell. The cancer cells send legions to every part of their world and start converting other cells. That is no different than Christianity, Buddhism, or any other ism. (n.p.) An example of a content item that fell within the lists category occurred when blogger Lisa Guidarini (2010) posted an Amazon.com review of The Immortal Life of 
Henrietta Lacks on her blog titled Bluestalking: Editor at Large of Her Own Life. The post is a direct link to the Amazon book review, under the post title: "Recently borrowed from my library" Guidarini described herself as a book reviewer and Reference and Adult Program Librarian. After the Amazon post she writes: “Note: I haven't read it yet, but it's in my hot little hands. It sounds great!” (n.p.). A second example of a content item that qualified for the lists category was on a blog called, "Harris Online" (with eight contributors identified by first name only). The post was titled: "Best Sellers by Area" (2010). The text below the title states: "What does it say about various locations when you compare bestsellers?" Three regions are represented, the Washington, D.C. area and the San Francisco Bay area, with a national comparison. Each list features the top ten non-fiction best sellers in the respective area. Under the D.C. non-fiction list, The Immortal Life of Henrietta Lacks is ranked ninth, under the Bay Area list the book is ranked fifth, and under the national non-fiction list, the book is ranked eighth. The blogger concludes: "I always look at the national bestseller list and scratch my head, even more than the Bay Area one. Maybe as a generalization, more politics in Washington, more lifestyle in San Francisco, more conservative reading interests overall in nationally" (n.p). The nature of the content listing lands this post in the lists category.

An example of a content item that qualified for the book publicity category was a post on one of Skloot's blogs named "Culture Dish" on scienceblogs.com. She posted a trailer (a video) for the first leg of her book tour. The video caption reads:

People often ask whether the Lacks family has joined me for any of my book tour events and how they feel about the book. Here, in the first of what will be several 
trailers of The Immortal Book Tour, you can see bits of the tour, including the blizzard that nearly prevented me from getting there, many great photos, footage of several Lacks family members talking about the Immortal Life of Henrietta Lacks, and more. (Skloot, 2010b, n.p.)

This content item qualified for the book publicity category because Skloot is promoting her book on her own blog, highlighting her book tour.

Another category that I decided described the frames concerned the author, personally. An example is a feature written by Marc Covert in The Oregonian's online platform OregonLive (2010). The article is titled "Rebecca Skloot's first book presents the immortal life of Henrietta Lacks and the debt we owe her." The article begins with a brief overview of the book, but transitions to biographical information about Rebecca Skloot:

A self-described "science nerd" who grew up in Portland, the daughter of writer Floyd Skloot, Rebecca Skloot first heard about Henrietta Lacks and the HeLa cell line at Portland Community College in 1988. When she asked her instructor where Lacks was from, whether she had any children or if she ever knew what her cells had done for so many people, he couldn't tell her a thing - "no one knows anything about her," he said with a shrug. (Covert, 2010, n.p.)

An example of a content item that qualified for the social reading category was a blog for an advanced placement biology class. The teacher listed upcoming quizzes and book chapters as well as a reference to an upcoming field trip: 
Tuesday (3/30/10): Finish Excretory System. Plus field trip to UAB to hear author Rebecca Skloot discuss her new book, The Immortal Life of Henrietta Lacks. (Reardon, 2010, n.p.)

This content item qualified for the social reading category because of the emphasis on the people reading (or interacting) with the book as opposed to the book itself, and the social aspects surrounding the book. The aforementioned examples are intended to describe the type of discourse encompassing The Immortal Life of Henrietta Lacks.

In summary, I determined the eight prominent frame categories: 1) exploitation, 2) science, 3) ethics, 4) projection (renamed from antrhopomorphism), 5) lists, 6) book publicity, 7) Skloot, and 8) social reading. Later, two other categories were added: unknown and other. Unknown and other are not frames. Unknown is a designation for indeterminant frames, and other is a designation for any content that did not fit into the other categories. Exploitation, science, ethics, anthropomorphism (later renamed projection), and Rebecca Skloot are frame categories that attend to Culler's (1997) close reading approach, "What is this about?" Book publicity and social reading appeal to the strategic function of framing (Molotch \& Lester, 1975). Lists qualifies as a frame that functions as a structural component (Zillmann et al. 2004; Esser \& D'Angelo, 2003).

Confirmatory exercise. In order to test whether the categories were an appropriate way to sort the frames, I performed a confirmatory exercise. I approached 10 graduate students (a convenience sample) on March 31, 2011. I provided the judges with a sample of twenty web pages (content items), with two examples from each of the 10 categories I had already created. I told the judges how I selected the web pages and asked them to 
help determine if the category types made sense. I asked the group to discuss each example and tell me what type of category they would select for each web page. I wrote the 10 categories on the blackboard. I then asked each judge which category best described the web content. The group categorized each web page the same way I had categorized them. However, there was one adjustment. Recall that the category named anthropomorphism was renamed projection to expand the concept to include religious or contemplative discussions based on feedback from the student judges. Table 1 illustrates the final categories. 
Table 1.

Frame Categories

\begin{tabular}{|c|c|}
\hline Category & Frame Description \\
\hline Exploitation & $\begin{array}{l}\text { In the exploitation category, racial frames are assumed (i.e., "poor black } \\
\text { mother") and focused on the marginalized or vulnerable in reference to web } \\
\text { page content. For example: emphasis on "her children never knew," any } \\
\text { mention of Tuskegee, or overt emphasis on the Lacks family, poverty, race, } \\
\text { or gender. }\end{array}$ \\
\hline Science & $\begin{array}{l}\text { The science category is typically a laundry list of breakthrough research that } \\
\text { utilized HeLa cells. For example, research includes: in-vitro technology, the } \\
\text { Polio vaccine, treatment for sexually transmitted infections, and cancer } \\
\text { advances with a noticeable absence or minimization of biographical } \\
\text { information regarding Henrietta Lacks when it is the dominant frame. }\end{array}$ \\
\hline Ethics & $\begin{array}{l}\text { The ethics category is meant for frames that specifically address medical } \\
\text { ethics particularly in reference to professional practice, informed consent, } \\
\text { Health Insurance Portability and Accountability Act (HIPPA), genetic } \\
\text { ownership or health care reform. This frame does not focus solely on the } \\
\text { exploitation of vulnerable individuals, but is a more prescriptive approach } \\
\text { for a professional code of conduct or a call for a change in policy. }\end{array}$ \\
\hline $\begin{array}{l}\text { Projection } \\
\text { (Renamed from } \\
\text { Anthropomorphism) }\end{array}$ & $\begin{array}{l}\text { The projection category is for the contemplative, philosophical or abstract } \\
\text { frames. It can include expressions of gratitude or religiosity or can imply } \\
\text { that the cells have some sense of agency. It often takes the form of } \\
\text { discussing Henrietta Lacks' cancer cells as if they were her (as a person). } \\
\text { Examples include: Frankenstein analogies and phrases such as "she's a } \\
\text { mother to all of us," "she's an angel," "they shot her into space," and "they } \\
\text { injected her with AIDS." }\end{array}$ \\
\hline Lists & $\begin{array}{l}\text { The lists category is for cases where the title The Immortal Life of Henrietta } \\
\text { Lacks is listed with no other content related to the book. This category is not } \\
\text { limited to best seller lists, bit torrents, retail lists and library lists and } \\
\text { includes blog postings such as widgets that display "what I'm reading." } \\
\text { Lists is a significant category because it captures the conversational aspect } \\
\text { of the book's diffusion, by providing the structure for a content item. }\end{array}$ \\
\hline Book Publicity & $\begin{array}{l}\text { The book publicity category has two frame approaches: public relations } \\
\text { activity from the author that offers no more than the standard summary of } \\
\text { the book, if present. Examples include author speaking engagements } \\
\text { pertaining to The Immortal Life of Henrietta Lacks, excerpts from the book } \\
\text { without any editorializing and second, obvious plugs from the individuals } \\
\text { other than author with the "go out and buy this book" approach. }\end{array}$ \\
\hline
\end{tabular}




\begin{tabular}{|ll|}
\hline Rebecca Skloot & $\begin{array}{l}\text { The Rebecca Skloot category is restricted to biographical or professional } \\
\text { frames about the author. For example: "Rebecca Skloot is a science writer } \\
\text { and author of The Immortal Life of Henrietta Lacks." }\end{array}$ \\
\hline Social Reading & $\begin{array}{l}\text { The social reading category is for book clubs, or reading initiatives with an } \\
\text { emphasis on communal discussion frames, message board queries, } \\
\text { Craigslist's discussions, etc. Other examples include Black History Month, } \\
\text { solidarity, and homework questions. This category pertains to discussions not } \\
\text { so much about the book, but about the people reading the book. }\end{array}$ \\
\hline Unknown & $\begin{array}{l}\text { Unknown (or indeterminant) designation includes spam, 404s, server errors, } \\
\text { expired content, blocked content, and pages not in English. These links are } \\
\text { still an important part of the data because, for example, spammers or affiliate } \\
\text { marketers may put links in unrelated sites out of a response to users searching } \\
\text { the phrase, "Henrietta Lacks." Therefore, these pages are still reflective of } \\
\text { discourse and general public interest. }\end{array}$ \\
\hline Other & $\begin{array}{l}\text { The other designation is for content that does not qualify for any of the } \\
\text { categories stated above. }\end{array}$ \\
\hline
\end{tabular}

\section{Posteriori Process}

Equipped with category criteria, the next two steps in the procedure entailed retuning to the key events defined in Step Two: Plotting the data. The purpose of using the key events as a point of reference is to identify potential activity that spurred frames and sources. Focusing on these data points:(February 16, March 29, April 22, May 12, June 21 and July 21) I observed two things: 1) the emergent frame categories of content within these heightened spikes of activity, and 2) the sources associated with these content items. Notice that source data were not included in the confirmatory exercise, because sources are manifest. Unlike the latent frame data, sources did not require interpretation and were not included in the inter-coder test. In the following, I will discuss how I attended to emergent frames, tested inter-coder reliability, and finally, how I determined sources. 
Step Four: Close reading for frames. To address what emergent frames occurred, I created frame categories as detailed in the previous section. I then performed a second close reading procedure of the content items that appeared in the key event data. Frames emerged in the following categories: exploitation, science, ethics, projection, lists, book publicity, Rebecca Skloot, social reading, unknown and other (see Table 1). In the next chapter, Results and Analysis, I will discuss which emergent frames occurred on key event days.

Inter-coder Reliability. To check for consistency regarding how I categorized the content items within the frame categories, I conducted a procedure using inter-coder reliability. I randomly selected 23 pages from the pool (10 percent of the 233 web pages) for the test (Kaid \& Wadsworth, 1989; Lacy \& Riffe, 1996; Neuendorf, 2002; Wimmer \& Dominick, 1991). I gave two volunteer coders identical packets consisting of examples of web pages (screen shots) as well as the original alert information (screenshots of original URLs and content summaries) provided by Google. A coding sheet that corresponded to the web page examples was also included. On the coding sheet the coders were asked to check one of ten boxes (each representing a category) and match each page with a frame category. In this reliability check, a matrix was constructed to sort coder responses to frame categories only, since there were only 10 possible options (See Table 1) (Brennan \& Prediger, 1981; Randolph, 2005; Randolph, 2008; Siegel \& Castellan, 1988; and Warrens, 2010). The coders were given a week to complete the packet (see Appendix for coding packet). 
I used Cohen's Kappa as a statistical measure to check agreement on the framing categories (Cohen, 1960). The percent of overall agreement was 0.61 on kappa frame categories. With a $61 \%$ overall reliability rate, the agreement is substantial according to the literature. This reliability rate is acceptable in the social sciences (for kappa), specifically in regard to content analysis (Babbie, 1997). Statisticians have adopted the following guidelines for what constitutes as a "good" reliability percentage in this context: zero to $20 \%$ agreement as slight, $21 \%$ to $40 \%$ agreement as fair, $41 \%$ to $60 \%$ agreement as moderate, $61 \%$ to $80 \%$ agreement as substantial, and $81 \%$ to $99 \%$ agreement as "almost perfect" (Landis \& Koch, 1977).

Step Five: Close reading for sources. To determine the sources, I noted the individuals and organizations named. Recall that by "sources," I mean any individual mentioned or identified in the "online coverage." Earlier, I discussed that a "source" is similar to an "opinion leader" in that they are both transmitters of information. Therefore, I counted the frequency of sources in the key event data. For example, sources included Oprah Winfrey, Allan Ball, HBO Films, miscellaneous researchers, Alok Jha of Guardian UK, The Lacks Family, and various research institutions.

To further clarify the manifest nature of this type of information, I will provide examples from the data. Oprah Winfrey's flagship online enterprise, Oprah.com, was indexed by the Google alerts and linked on rebeccaskloot.com (Skloot, 2010c). The text read: "Oprah.com recommends The Immortal Life of Henrietta Lacks as an Ideal Mothers Day Gift... Oprah.com recommended 16 books as ideal mother's day gifts, and The Immortal Life of Henrietta Lacks was one of the first on the list" (n.p). 
Alan Ball was mentioned with Oprah Winfrey and HBO films often, however there were a few examples when Ball was the primary source. By primary source, I mean the only source mentioned within the content item. ${ }^{3}$ Those instances were found in content items associated with his previous production work with other HBO projects. One example came from a True Blood fan page, a site called: “True Blood News: A place to feed your obsession" (2010). True Blood is a project that Ball produced, a mini-series about vampires. A blogger who used the pseudonym "Lividity" wrote a post titled "True Blood's Alan Ball teams up with Oprah Winfrey." The content details Ball's involvement with the project and provides a synopsis of the book. The post features a photo of Ball and alongside the text are six advertisements for vampire-related merchandise. Lividity quotes Ball regarding his excitement about his next project (HeLa biopic): "I fell in love with it,' Ball said. 'I thought it would be a perfect movie for HBO. This is going to be a journey that we'll all remember for the rest of our lives" (n.p.). For a True Blood fan, Alan Ball's involvement is the salient aspect of this HeLa content item.

In summary, the methods for the current study are iterative and emergent. In the next section I will discuss how this procedure attends to the research questions that guide the study. The results and analysis will be presented concurrently as prescribed by the mixed-method approach to social research (Creswell \& Plano Clark 2006).

\footnotetext{
${ }^{3}$ If there was more than one source, each name was noted. In other words, unlike the frame categories, more than once source could be attributed to a single content item.
} 


\section{Chapter 5}

\section{RESULTS AND ANALYSIS}

The current study is guided by research questions that facilitate qualitative and quantitative inquiry. John W. Creswell and Vicki L. Plano Clark defined a research paradigm that encompasses both methodological approaches, called mixed method design. Creswell and Plano Clark (2006) stated, "Mixed methods research is 'practical' in the sense that the researcher is free to use all methods possible to address a research problem" (p. 10). A common approach to mixed methods analysis is data visualization, supported by a rich history in science communication (Onwuegbuzie \& Dickinson, 2008; Trumbo, 2001; Tufte, 2006). The process summarizes and highlights important aspects of the data for comparative purposes, while simultaneously providing context (Dickinson, Hines \& Onwuegbuzie, 2006; Onwuegbuzie \& Dickinson, 2008; Tashakkori \& Teddie, 1998; Tufte, 2006).

The qualitative component of mixed method design permits the researcher to report the results and follow with analysis. For example, Thomas R. Lindlof and Bryan C. Taylor, in their book Qualitative Communication Research Methods, note that one of the strengths of qualitative analysis is the ability to revise one's views after examining data (2002, p. 223). In the specific context of mixed method analysis the act of reducing and highlighting the data in a visual manner is iterative, inductive process that can help researchers see evidence. For example, Miles and Huberman (1994) stated that the purpose of a data visualization is for the researcher to "see what is happening and either draw justified conclusions or move on to the next step of analysis the display suggests is 
useful" (p. 11). Thus, in this section I will present the results through data visualization, followed by an interpretive analysis and consider what the findings mean.

Recall that I undertook a multi-step methodological process. I first collected data of the online coverage on The Immortal Life of Henrietta Lacks by signing up for Google alerts. The data collection yielded 3,838 units of online content from February 7 to August 5, 2010. I mapped the data to visually describe the book release over time while observing spikes in coverage (key events). I developed criteria for a textual analysis of the data. I then performed a close reading of the content items culled from the sampling procedure, and identified the emergent frames within the online coverage and placed them into categories. I returned to the data and performed a close reading of the content items in the key data points (identified in step 2) while recording the prominent frame category for all online coverage in these zones of heightened activity. I then observed mentions of sources in the same content items.

In the following section, I will attend to each research question by discussing the map, emergent frames, sources, and finally, the intersection of sources and frame categories.

\section{The Google Alert Map}

In order to describe the diffusion of the online coverage and address Research Question 1, I mapped the data. Figure 2 in the preceding chapter shows the pattern of activity that displays the diffusion of online coverage surrounding the release of The Immortal Life of Henrietta Lacks. Six points are prominent visually: February 16, March 
29, April 22, May 12, June 21 and July 21. Looking closely, a pattern emerges. May 12 is the highest peak, nearly midway through the time frame, and then the activity is relatively quiet from May 12 to around June 2. The key events emerge every three to four weeks.

The overall activity is an oscillation, varying over time and repetitive in nature with dramatic peaks and valleys. Since there are very few plateaus, it seems that the online coverage was made of spurs of activity. Interestingly, there appears to be a major dip in coverage immediately before each major data spike. In the current study, the difference in coverage can be relative silence (three alerts) to a major jump (29 alerts) as seen in February 16.

The spurs of activity seem to follow a news routine pattern, as there are no Fridays or weekends in the key events: February 16 is a Tuesday; March 29 is a Monday; April 22 is a Thursday; June 21 is a Monday; and July, 21 is a Wednesday. Furthermore, no major spikes occurred on a Sunday, one key event fell a Wednesday, and two were 24 hours from falling on a Wednesday. At this point, the overall pattern of diffusion provides insight on how the message spread. Therefore, by creating a map of alerts over time, I effectively answered Research Question 1: How was The Immortal life of Henrietta Lacks diffused online? Next, to delve deeper into these findings, I looked at messages themselves: emergent frames.

\section{Emergent Frames}

Turning to the Research Question 2a, What emergent frames are associated with diffusion of The Immortal life of Henrietta Lacks?, I performed a close reading of all 
content items in the six key event days and then grouped the frames into 10 categories (See Table 2). My intent was to indentify emergent frames in order to lay the ground work for a deeper explanation of heightened online activity during specific points in time (Research Question 2b).

The unknown (or indeterminate) category was most prevalent with 55 counts in a pool of $233(23.6 \%)$ followed by the science category at $17.2 \%(n=40)$; the lists category at $13.7 \%(\mathrm{n}=32)$; the exploitation category at $10.3 \%(\mathrm{n}=24)$; the social reading category at $9 \%(n=21)$; the book publicity and Rebecca Skloot categories both at $7.7 \%(n=18)$; the ethics category at $6.4 \%(n=15)$; the projection category at $3.4 \%(n=8)$; and finally, the other category at $.01 \%(\mathrm{n}=2)$. Recall that the unknown (or indeterminate) is a category for content for which no one frame could be determined. Table 2 represents categories by frequency and percentage in all key events $(\mathrm{N}=233)$. 
Table 2.

Categories by Frequency and Percentage of all Key Events

\begin{tabular}{lll} 
Category & Frequency & Percentage \\
\hline Unknown* & 55 & $23.6 \%$ \\
Science & 40 & $17.2 \%$ \\
Lists & 32 & $13.7 \%$ \\
Exploitation & 24 & $10.3 \%$ \\
Social Reading & 21 & $9.0 \%$ \\
Book Publicity & 18 & $7.7 \%$ \\
Rebecca Skloot & 18 & $7.7 \%$ \\
Ethics & 15 & $6.4 \%$ \\
Projection & 8 & $3.4 \%$ \\
Other* & 2 & $0.01 \%$ \\
\hline Total & $\mathbf{2 3 3}$ & $\mathbf{1 0 0 \%}$ \\
\hline
\end{tabular}

$\mathrm{N}=233$ represents the total number of web pages in the six days of key events. Recall that unknown and other are categories, not frames.

In summary, science emerged as the most dominant, definable frame category across all key events. Recall the science category captures breakthrough research that utilized HeLa cells. These include items focusing on in-vitro technology, the Polio vaccine, treatment for sexually transmitted infections, and cancer breakthroughs. Lists was the second most dominant category. Recall that the lists category included cases where the title The Immortal Life of Henrietta Lacks is listed with no other content related to the book. Examples include: best seller lists, bit torrents, retail lists and library lists and includes blog postings such as widgets that display "what I'm reading." Looking 
at source data (Research Questions 3a and 3b) will help illuminate why the list category emerged so often, because the category is tied to retailers and book reviewers. The third most prominent category across all data sets was exploitation. Rebecca Skloot's book was about an impoverished African-American woman who had her cells cultured without her knowledge, and the subject matter may have spurred discussions of exploitation and racism.

To further understand what factors encouraged the emergence of certain frames, I will analyze frame emergence by key event to establish whether patterns of activity (in the publicity campaign) may have been a factor. Therefore, in the following section, I will address Research Question 2b: Do any discernable patterns describe the frequency of frames that emerged in the online diffusion of The Immortal life of Henrietta Lacks?

\section{Emergent Frames by Key Event}

My next objective was to see if the frames followed any discernable patterns. I then examined each of the six key event days for prominent frame categories. On February 16, the prominent frames were the Rebecca Skloot and lists categories (13.8\%), followed by exploitation, science, and book publicity categories (10.3\%). On March 29, the prominent frames were the science and lists categories (17.9\%), followed by the exploitation, book publicity and social reading categories $(10.3 \%)^{4}$. On April 22, the prominent frame was the ethics category (15\%) followed by the science and social reading categories $(12.5 \%)$. On May 12, the prominent frame was the exploitation

\footnotetext{
${ }^{4}$ I discuss any categories that comprised at least $10 \%$ of the total coverage in the key event day (Neuendorf, 2002).
} 
category (24\%) followed by the science (14\%), Rebecca Skloot (12\%) and book publicity (10\%) categories. On June 21, the prominent frame was the science category $(32.6 \%)$ followed by the lists category (11.6\%). On July 21, the prominent frame was the lists category (28.1\%), followed by the social reading category (21.9\%) and the science category $(12.5 \%)$. 
Table 3.

Frame Categories by Key Event

February 16, 2010

March 29, 2010

\begin{tabular}{|lll|lll|}
\hline Category & Count & $\%$ & Category & Count & $\%$ \\
\hline Unknown & 8 & $27.6 \%$ & Science & 7 & $17.9 \%$ \\
Lists & 4 & $13.8 \%$ & Lists & 7 & $17.9 \%$ \\
Skloot & 4 & $13.8 \%$ & Unknown & 6 & $15.4 \%$ \\
Exploitation & 3 & $10.3 \%$ & Exploitation & 4 & $10.3 \%$ \\
Science & 3 & $10.3 \%$ & Book Publicity & 4 & $10.3 \%$ \\
Book & 3 & $10.3 \%$ & Social Reading & 4 & $10.3 \%$ \\
Publicity & 3 & $6.9 \%$ & Ethics & 2 & $5.1 \%$ \\
Ethics & 2 & $3.4 \%$ & Projection & 2 & $5.1 \%$ \\
Projection & 1 & $3.4 \%$ & Skloot & 2 & $5.1 \%$ \\
Social & 1 & $0.0 \%$ & Other & 1 & $3.0 \%$ \\
Reading & 1 & $\mathbf{1 0 0 \%}$ & Total & $\mathbf{3 9}$ & $\mathbf{1 0 0 \%}$ \\
Other & 0 & $\mathbf{2 9}$ & & & \\
\hline Total & & & & & \\
\hline
\end{tabular}


Table 3.

Frame Categories by Key Event (continued)

\begin{tabular}{|lll|lll|}
\hline \multicolumn{3}{c}{ April 22, 2010 } & \multicolumn{5}{c|}{ May 12, 2010 } \\
\hline Category & Count & $\%$ & Category & Count & $\%$ \\
\hline Enknown & 13 & $32.5 \%$ & Unknown & 13 & $26.0 \%$ \\
Science & 5 & $15.0 \%$ & Exploitation & 12 & $24.0 \%$ \\
Social & 5 & $12.5 \%$ & Science & 7 & $14.0 \%$ \\
Reading & 5 & $12.5 \%$ & Skloot & 6 & $12.0 \%$ \\
Lists & 3 & $7.5 \%$ & Book Publicity & 5 & $10.0 \%$ \\
Book & 3 & $7.0 \%$ & Lists & 4 & $8.0 \%$ \\
Publicity & 2 & $5.0 \%$ & Ethics & 1 & $2.0 \%$ \\
Exploitation & 2 & $7.5 \%$ & Projection & 1 & $2.0 \%$ \\
Skloot & 2 & $2.5 \%$ & Social Reading & 1 & $2.0 \%$ \\
Projection & 1 & $0.0 \%$ & Other & 0 & $0.0 \%$ \\
Other & 0 & $\mathbf{1 0 0 \%}$ & Total & $\mathbf{5 0}$ & $\mathbf{1 0 0 \%}$ \\
\hline Total & $\mathbf{4 0}$ & & & & \\
\hline
\end{tabular}


Table 3.

Frame Categories by Key Event (continued)

June 21, 2010

July 21, 2010

\begin{tabular}{|lll|lll|}
\hline Category & Count & $\%$ & Category & Count & $\%$ \\
\hline Science & 14 & $32.6 \%$ & Lists & 9 & $28.1 \%$ \\
Unknown & 9 & $20.9 \%$ & $\begin{array}{l}\text { Social } \\
\text { Reading }\end{array}$ & 7 & \\
Lists & 5 & $11.6 \%$ & Unknown & 6 & $21.9 \%$ \\
Ethics & 4 & $9.3 \%$ & Science & 4 & $18.8 \%$ \\
Exploitation & 3 & $7.0 \%$ & Skloot & 3 & $12.5 \%$ \\
Book & 3 & $7.0 \%$ & Projection & 2 & $9.4 \%$ \\
Publicity & 3 & $7.0 \%$ & Other & 1 & $6.3 \%$ \\
Social & 3 & $2.3 \%$ & Projection & 0 & $3.1 \%$ \\
Reading & 1 & $2.3 \%$ & Ethics & 0 & $0.0 \%$ \\
Projection & 1 & & Book & & $0.0 \%$ \\
Skloot & 1 & $\mathbf{1 0 0 \%}$ & Total & $\mathbf{3 2}$ & $\mathbf{1 0 0 \%}$ \\
\hline Other & 0 & $\mathbf{4 3}$ & & & \\
\hline Total & & & & & \\
\hline
\end{tabular}

To summarize, Table 3 illustrates a breakdown of each frame category that appeared on the six key event days. (Recall that the goal of the current research is not to track a single frame through time, but to provide a snapshot of what frames were prominent during heightened periods of activity.) Table 2 and Table 3 display the same data set, but Table 3 provides an additional level of detail: frames by specific key event day. Another way to look at the data is to create a figure to help make key event trends more evident. Thus, Figure 3 provides a way to identify possible patterns. Here, one can 
see that five frame categories (out of nine) appeared on each key event day: science (17.2\%), lists (13.7\%), social reading (9.0\%), Skloot (7.7\%) and projection $(3.4 \%)$ (recall that unknown is not a frame category). To understand what other elements could be involved, I will discuss each frame category in relation to how it emerged in each of the six key events, and later, what sources were associated with the frames. 
Figure 3.

Categories by Key Event

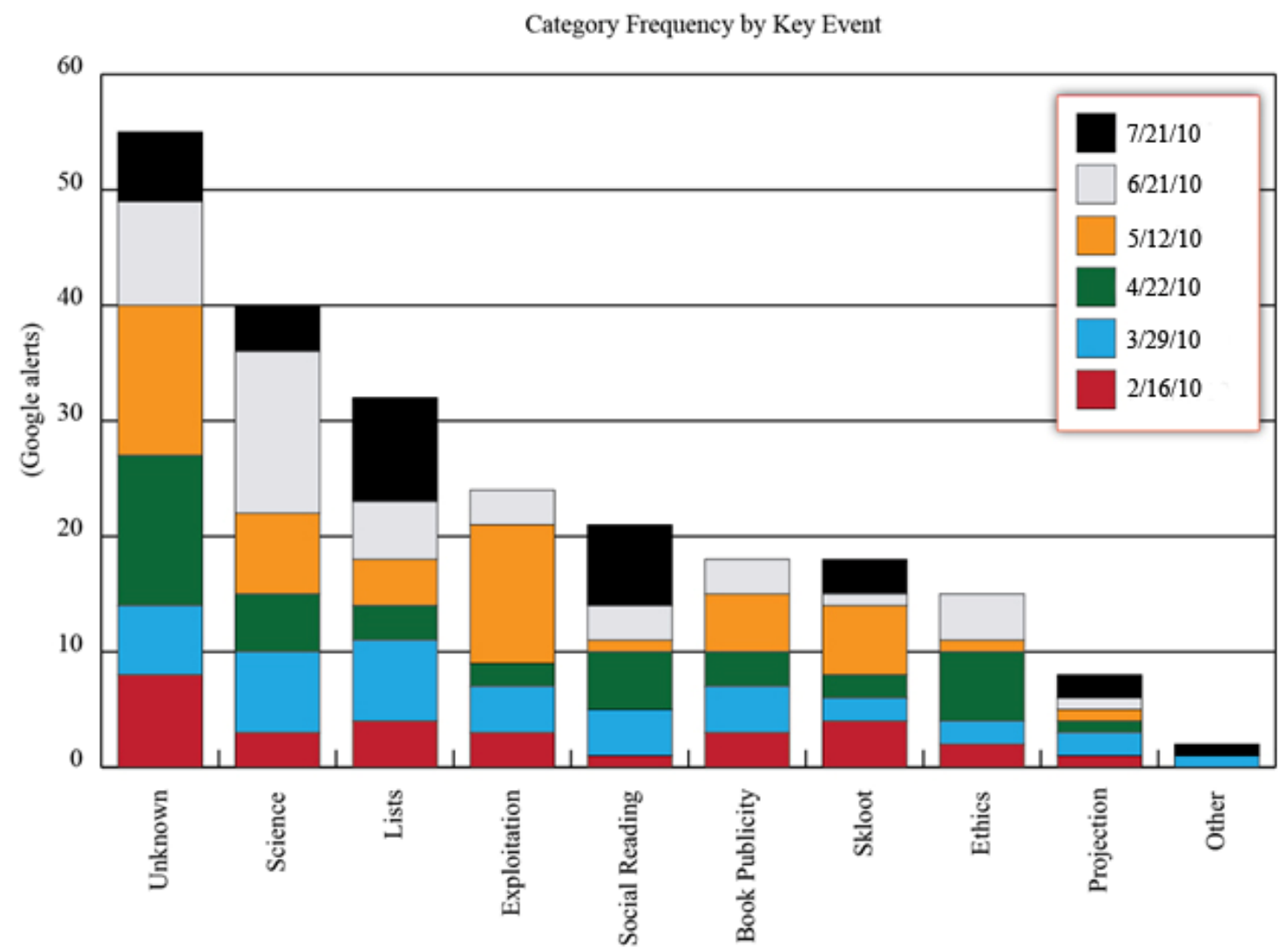

Looking at Figure 3, the top three categories unknown, science and lists display the same six key event dates. However, the fourth highest category, exploitation looks different. For the exploitation category, there are no occurrences on July 21, and more than half of the total occurrences on May 12. Conversely, social reading had a major presence on July 21 and very little presence on May 12.

Book publicity (7.7\%, overall) did not have any presence in July 21 but was somewhat evenly divided among the five earlier key events. The Rebecca Skloot category (7.7\%, overall) had a minimal presence on June 21 (2.3\%) and sizeable presence on May 
$12(2.0 \%)$. The ethics category (6.4\%, overall) had no presence on July $21(0.0 \%)$ but a noticeable presence on April 22 (15.0\%), which is the first time (other than unknown) that April 22 emerges as a key day for a category. The projection category $(3.4 \%$, overall) is nearly spread evenly across all key events, signifying a small smattering in the overall frame data. The Other category $(0.01 \%$, overall) appears just twice, on March 29 and on July 21.

In addressing Research Question 2b (Do any discernable patterns describe the frequency of frames that emerged in the online diffusion of The Immortal life of Henrietta Lacks?) most frame categories are present throughout the key event days. However, there are a few exceptions: for example, the appearance of the exploitation frame, which has an unusually high concentration on May 12 (compared to other categories). In summary I found that there were no major differences in how each frame category diffused, with the exception of exploitation not appearing on July 21 at all. The book publicity and ethics categories also lacked a presence on July 21, however, since these frames were not prominent categories, it is difficult to draw any conclusions based on this limited snapshot. Therefore, to understand what factors may have contributed to some frame categories gaining traction over others at specific points in time, next I turned to sources. 


\section{Sources}

To explore which sources are associated with online diffusion of The Immortal life of Henrietta Lacks (Research Question 3a), I counted sources mentioned in the web pages from the key event days. Among the 201 sources mentioned, Oprah Winfrey was most prominent at 15.9\%. Allan Ball (True Blood and Six Feet Under producer) followed with $11.9 \%$ (See Table 4). 
Table 4.

\section{Sources}

\begin{tabular}{|c|c|c|}
\hline Source & Count & $\%$ \\
\hline Oprah Winfrey & 32 & $15.9 \%$ \\
\hline Alan Ball & 24 & $11.9 \%$ \\
\hline Miscellaneous* & 23 & $11.4 \%$ \\
\hline HBO Films & 19 & $9.4 \%$ \\
\hline Newspapers & 18 & $8.9 \%$ \\
\hline Scientists and Researchers & 17 & $8.4 \%$ \\
\hline Science writers & 11 & $5.4 \%$ \\
\hline Universities/Research Institutions & 7 & $3.4 \%$ \\
\hline Producers & 6 & $2.9 \%$ \\
\hline Radio shows & 6 & $2.9 \%$ \\
\hline Lacks Family Members & 5 & $2.4 \%$ \\
\hline Amazon.com & 5 & $2.4 \%$ \\
\hline David Prete (actor, Skloot's partner) & 5 & $2.4 \%$ \\
\hline Fritzi Bodenheimer (public speaking coach) & 5 & $2.4 \%$ \\
\hline Steve Ember (voice-over actor) & 5 & $2.4 \%$ \\
\hline Popular Science Publications & 4 & $1.9 \%$ \\
\hline Libraries/Book Groups & 3 & $1.4 \%$ \\
\hline $\begin{array}{l}\text { John Moore } \\
\text { (Moore v. Regents of the University of California) }\end{array}$ & 3 & $1.4 \%$ \\
\hline Stephen Colbert (comedian) & 3 & $1.4 \%$ \\
\hline Total & 201 & $100 \%$ \\
\hline
\end{tabular}

Table 4 displays the groups of sources $(\mathrm{N}=201)$ that emerged within the content units of the key event data.

*Miscellaneous is a group that refers to any individuals or organizations that were less than one percent of the overall source data and did not apply to the other collapsed categories because they were too dispersed to constitute their own group. A detailed description of the rationale behind group collapsing process follows. However, an uncategorized list of sources by key event date is available in Appendix A. 
While analyzing the data, I found a scattering of diverse, disparate sources in the online diffusion of The Immortal Life of Henrietta Lacks. To better understand the sources, I organized them into groups using the following criteria: uniqueness (the lack of commonality between sources) or frequency over $10 \%$ of total data. For further clarity, the miscellaneous group referred to any individuals or organizations that garnered less than one percent of the overall source data and those that did not fit within other collapsed categories (conceptually). Sources relegated to the miscellaneous group fell within two criteria: 1) less than one percent of the data and 2) not applicable to the following collapsed categories: Newspapers; Science writers; Producers; Universities and Research Institutions; Lacks Family Members; Radio shows; Popular Science Publications; and Libraries and Book Groups. Examples of miscellaneous sources include: TED Talks, a nonprofit consortium that specializes in technology, education and design trends and the web-based collaborative encyclopedia, wikipedia.com.

For further detail on how I categorized other sources, the newspaper group contained sources such as The New York Times; The LA Times; The Chicago Tribune; The Philadelphia Independent; The Wall Street Journal and The Washington Post. Science writers were often affiliated with newspapers but had a special status if they were continuously referred to by name, secondary to their organization. Science writers included individuals such as Alok Jha (Guardian UK), Liz Hunt (UK Telegraph), and Maggie Korth-Baker (boingboing.net). Producers included those affiliated with the HBO biopic such as Kate Forte and Peter Macdissi, as well as those that have been affiliated with other productions pertaining to HeLa cells such as Adam Curtis (who produced a 
BBC documentary called The Way of the Flesh). Universities and Research Institutions pertained to sources such as to Arizona State University, recently embroiled in litigation regarding genetic ownership, as well as various institutions that Skloot visited during her book tour, such as Chico State, Columbia University, and the University of California at San Diego. Lacks Family Members most often pertained to Lacks' children specifically Deborah, Elsie and Gary Lacks. Radio Shows included NPR's Fresh Air with Terry Gross, Radiolab; Deborah Cameron with ABC Sydney; and WHYY's Radio Times. Popular Science Publications include Smithsonian Magazine, Wired Magazine and the Discovery Channel's Not Exactly Rocket Science. Libraries and Book Groups included Newport News Public Library and Caitlin Gable (a school in Portland, OR) science teachers' resource group.

I found that the 201 sources were scattered throughout each key event date with a few exceptions. For example, miscellaneous (11.4), HBO Films (9.4\%), newspapers (8.9\%) and individual scientists and researchers (8.4\%) were mentioned with some frequency, and they comprised of $65.9 \%$ of the total data. Exceptions to this pattern were individual science writers (5.4\%) and all of the sources that had a frequency below $(5.4 \%)$.

In summary, prominent sources were Oprah Winfrey and Alan Ball. However, like observing frames in key event data, I wanted to look closer to see if some sources (or source categories) had a stronger presence than others. Next, my intent was to explore whether the presence of a source pattern was associated with a specific key event date. 


\section{Source groups by key event}

To address Research Question 3b: Do any discernable patterns describe the frequency of sources that emerged in the online diffusion of The Immortal life of Henrietta Lacks?, I created an additional figure. Figure 4 illustrates which sources appeared on which key event. 
Figure 4.

Source Frequency by Key Event

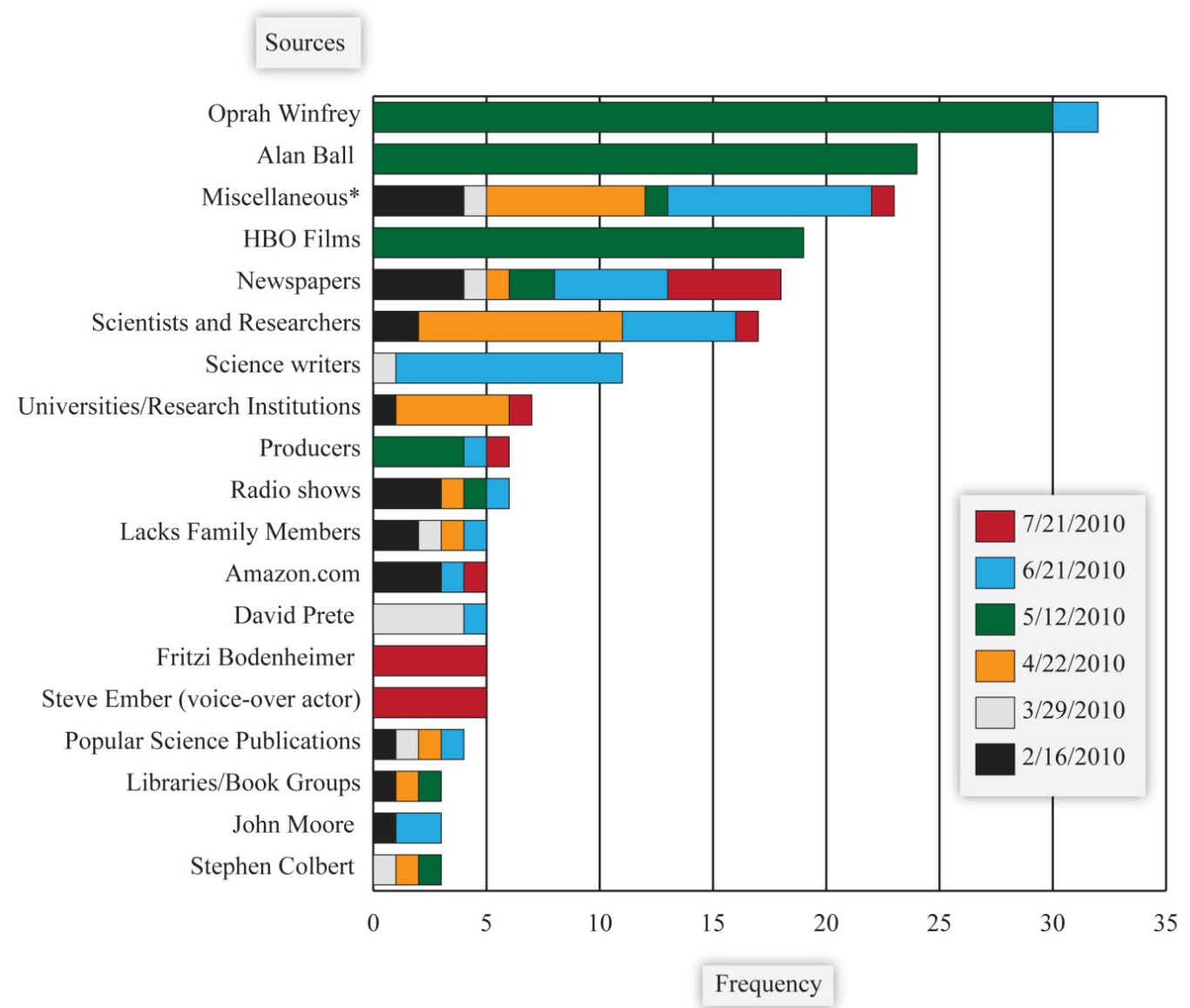

* Recall the miscellaneous group refers to any individuals or organizations that garnered less than one percent of the overall source data and did not apply to the other collapsed categories.

Turning to Figure 4, one can see which sources were dominant during the six clusters of heightened activity. Oprah Winfrey is the most frequent source, appearing almost entirely on May 12, with a few occurrences on June 21. Likewise, the second most frequent source is Alan Ball who appears only on May 12. Miscellaneous appears throughout the key events (recall that miscellaneous is a source group that refers to any individuals or organizations that were less than one percent of the overall source data and did not apply 
to the other collapsed categories because they were too dispersed to constitute their own group.) However, due to the nature of the miscellaneous group, a collection of scattered sources that lack commonality with one another, this pattern is not particularly meaningful in drawing conclusions regarding influential sources. The fourth most frequent source is HBO films which only appeared on May 12. Oprah Winfrey, Alan Ball and HBO Films all are prominent on May 12 because at that time, an announcement was made regarding a Henrietta Lacks movie, according to the information provided by the close-reading procedure. Winfrey accounted for 32 of the 84 source mentions on May 12 (38.1\% of the source mentions on May 12). HBO Films and True Blood producer Allan Ball were also possibly associated with this spike because of their involvement with a proposed movie about Henrietta Lacks.

The newspaper group displayed a presence in February 16, June 21, and July 21. Other than the miscellaneous group, the newspaper group had the strongest presence on February 16. Like opinion leaders in diffusion, the newspaper group may have served to legitimize the book in the earliest stage of the publicity campaign (Rogers, 2005).

The next largest source group, scientists and researchers, had the highest occurrence on April 22. When the science writers group occurred, it was most prominent on June 21. Of the 45 sources in the science writers group, many were writing for British publications, for example: Alok Jha (Guardian UK science writer) was mentioned seven times and Liz Hunt (UK Telegraph science writer) was mentioned twice. The universities and research institution group mirrored the scientists and researchers pattern, with the exception of appearing on June 21 . When the producers group occurred, it was most 
prominent on May 12. This insight is not surprising because producers are typically associated with the entertainment industry, and were perhaps tied to the movie announcement in some way.

When the radio show group occurred, it was most prominent on February 16, similar to the newspaper group. When the Lacks family group occurred, it was most prominent on February 16. The Amazon.com source occurred mostly February 16. The next source is David Prete. Prete is Skloot's partner, and the videographer of the publicity trailers for the book tour according to the information provided by the close-reading procedure. When Prete occurred as a source, he was most prominent of March 29.

Both Fritzi Bodenheimer and Steve Ember had a strong, but singular, presence on July 21. The close-reading procedure indicated that these two sources published an interview about the origin of HeLa cells based on content from The Immortal Life of Henrietta Lacks. The interview was part of coursework meant for English as a Second Language (ESL) students to expand their English proficiency.

The popular science publication group appeared evenly in every key event day with the exception of July 21 . Next, Libraries and book groups appeared in small but proportional amounts on February 16, April 22, and May 12. Recall that in the Immortal Life of Henrietta Lacks, Skloot mentions a man, John Moore who sued his doctor for selling his spleen. In the source data, John Moore is mentioned multiple times, with the greatest number of occurrences on June 16. Finally, comedian Stephen Colbert appeared on March 29, April 22, and May 12. 
Looking at how sources and key events intersect, a pattern emerges among the prominent sources. Oprah Winfrey and Alan Ball occur almost exclusively on May 12. Together, Winfrey and Ball comprise of almost a quarter of all source mentions but are rarely mentioned again in the subsequent key events. The third most prominent source (after miscellaneous) is HBO Films which also appeared exclusively on May 12. In summary, the three most prominent sources emerged on the same key event day and were all associated with an announcement about a forthcoming Henrietta Lacks movie. How, then, was this movie announcement framed, in addition to other source-related content? Thus, my next objective was to explore whether the presence of a source was associated with a specific frame pattern.

\section{Comparing Sources to Frame Categories}

Recall Research Question 4; Do source patterns have any association to frame patterns observed in the diffusion of The Immortal Life of Henrietta Lacks? By examining the relationship between source and frame, I can link together framing and diffusion literature. That is, I can see what role opinion leaders within a social network have on a salience transfer. To return to the literature, sources have the ability to frame messages that create media agendas. Therefore, if the media have the ability to set the public agenda, then sources become agents of diffusion because they transfer salience (McCombs \& Shaw, 1972; Rogers 1995).

In the current study, one way to investigate source association with potential activity-spurring frames is to: 1) look at how sources are clustered on key event days and, 
2) overlay sources with frames by key events. Therefore, in Figure 5, I overlaid two bar charts. That is, I took the frame categories for each key event and compared them to the sources mentioned on that day (See Figure 5). 
Figure 5.

\section{Framing Categories by Source}

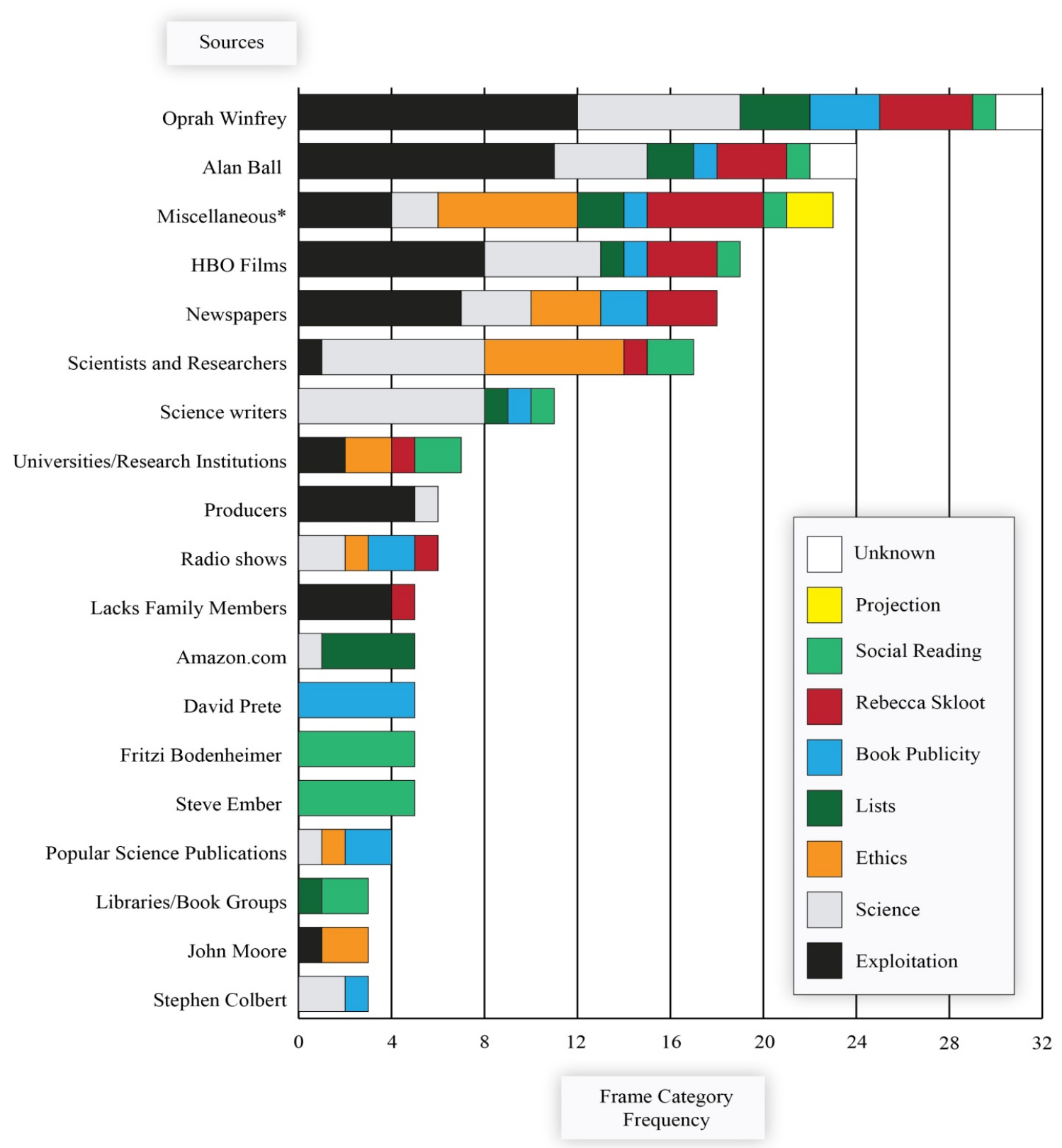

*Recall that the miscellaneous is a group that refers to any individuals or organizations that were less than one percent of the overall source data and did not apply to the other collapsed groups. 
By overlaying the two frequency tables of frames and sources, I could see how the type of frames intersected with such sources as Oprah Winfrey, Alan Ball, and HBO Films. For example, the source with the greatest frequency, Oprah Winfrey, overlapped with the following frame categories: exploitation, science, lists, book publicity, Rebecca Skloot, and social reading.

The newspaper group also displayed a strong relationship with the exploitation frame; a similar pattern found with sources associated with the Henrietta Lacks movie announcement. Next, I examined the scientists and researchers group which was closely associated with science and ethical categories. The universities and research institutions group exhibited the following frame categories: exploitation, ethics, Rebecca Skloot, and social reading.

The producer group was most commonly associated with the exploitation category. Because producers often work in the entertainment industry, a connection to the Henrietta Lacks movie (e.g., Peter Macdissi and Kate Forte) mirrored Oprah Winfrey, Alan Ball, and HBO Films. The next source group, radio shows, displayed the following frame categories: science, ethics, book publicity, and Rebecca Skloot.

The Lacks family members intersected with just two frame categories, exploitation and Rebecca Skloot. In regard to the strong association with exploitation, latent factors such as themes from the book may have influenced this relationship, or the pattern could have emerged due to the way the frame category was designed to include discussions of race, as the Lackses are an African-American family. 
The Amazon.com source intersected with the science and lists categories, but mostly lists. One reason could be that since Amazon is an e-retailer content mentioning Amazon was related to listings or adjectives such as Amazon top-seller, etc. The next three sources intersected with just one frame category: David Prete with the book publicity category and Fritzi Bodenheimer and Steve Ember, both with the social reading category. Recall that Prete is Skloot's partner and tour videographer; therefore it makes sense that this source is closely coupled with the book publicity category. Regarding Bodenheimer and Ember, recall that they were both involved in English as a Second Language (ESL) curriculum. In the close-reading procedure I found that content related to these two sources appeared on various Asian websites. The popular science publication group, the libraries and book clubs group, John Moore and Stephen Colbert all account for 10 percent or less of the total source and frame intersections. Therefore, patterns at this level are difficult to assess since the numbers are so small.

\section{Summary}

I identified how The Immortal Life of Henrietta Lacks was diffused by mapping the Google Alerts across a 180 day period. To further describe what factors may have accelerated the diffusion, I identified heightened clusters of activity, key events. Within those key events I identified frame and source patterns. I found that the three most prominent frames were science, lists and exploitation. I found that Oprah Winfrey, Alan Ball and HBO Films dominated the source data. Winfrey and Ball emerged prolifically on May 12, however, they did have a noticeable presence in the subsequent key event 
dates. My general questions about source and frame patterns provided the necessary foundation to explore the cornerstone of the current study (Research Question 4), the juncture of frame patterns and source occurrences. For example, Oprah Winfrey had the farthest reach of all sources, and was associated with a multitude of frames (seven different categories), yet occurred in a singular moment in time (almost entirely on May 12). What do these findings about influential sources and prominent frames indicate about how The Immortal Life of Henrietta Lacks gained traction online? In the next section, I will discuss what the frames and associated sources reveal. Specifically, I will address what this relationship reveals about power. Ultimately, this snapshot of the book's diffusion can provide insight on a broader discussion of the landscape of the internet. 


\section{Chapter 6}

\section{DISCUSSION}

The current case study sought to explore how messages become meaningful online. My interest links to Walter Lippmann's notion that we build our knowledge by extracting information from our experiences and our relationships with mediated information. However, I also recognize that not all meanings are equal, in the sense that some ideas become more salient for publics, and I ask, how does this occur?

Some critics, such as Michel Foucault, argue that the ability to create salience is a form of power, in that publics may be more likely to attend to meanings they find personally salient. Thus, in order to address how some ideas become more salient, I examined one phenomenon - the online coverage of a popular science book-to investigate how some attributes of coverage might help us better understand how information spreads_-diffuses—on the internet. By synthesizing these attributes of coverage - frames, sources, and the intersection of frames and sources—we can better understand how meaning is constructed on the internet.

\section{Frames}

Recall that one important element of my investigation was the description of how information was characterized, which I operationalized as "frames" of messages. Here, the key indicator of online salience is the way the messages are framed. In other words, frames may reveal audience salience, which becomes a complex concept when you recall 
that internet users are simultaneously producers and consumers of information (Levinson, 2009).

Although frames varied in terms of their characteristics throughout the 180 day period after the book's launch, some frames dominated online coverage: science, lists and exploitation. The science, lists and exploitation frame categories tell us what internet users found most salient in the online discourse surrounding The Immortal Life of Henrietta Lacks. For example, by focusing on cancer research, listing the book as a topseller, or by critically examining racial topics, the message was more likely to gain traction than those of other frame categories.

I believe science was salient because the book was positioned as a popular science book, so substantively speaking, this makes sense. (Recall that the science category encompassed topics such as the medical advances that resulted from the use of HeLa cells.) I believe lists was salient for three reasons. Retailers such as Amazon.com who listed the book may have more online capital than average, such as high visibility on search engines based on content production cycles and high visitor traffic. The popularity of the Blogger "What I'm Reading" widget throughout the data also contributed to the lists prominence. Blogger is a blogging platform owned by Google (Johnson, 2003). A Google bias may have contributed to the high number of Blogger entries retrieved by the Google Alerts. A third possibility for the prominence of the lists category is the nature of the case study subject—a book. The publishing industry often promotes books based on readership or sales, fertile ground for a proliferation of content based on lists or rankings. 
Exploitation appears to be salient due to the emphasis on drama and controversy. Nisbet, Brossard, and Kroepsch (2003) stated that the science topics that get the most coverage in the media are often the most dramatized, particularly in areas such as stem cell research. The book was about a scientific topic, HeLa cells. However, the discourse regarding the book touched on topics such as racism and poverty, because Skloot familiarized the reader with Lacks' upbringing in rural Virginia and her experiences a patient in the "colored ward" at Johns Hopkins. For one reason or another, these three frames resonated the strongest with internet users as they were the frames associated with the highest clusters of online activity.

The current study sought to understand the linkage between online activity and audience salience, and was grounded in the synthesis of framing and diffusion literature. In other words, if framing selects aspects of perceived reality with the intent of convincing audiences that the message is important, then framing and diffusion intersect at the salience transfer (Entman, 1993). Here, salience transfer describes the alignment of the audience's interpretation of a message with the objective of the information producer. This approach to salience transfer is a deeper description of the process that occurs within McCombs and Shaw's (1972) agenda-setting theory. To summarize, you can gain insight on what people find important by the traces of activity they leave on the internet. In the context of the current case study, those participating in the online discourse surrounding The Immortal Life of Henrietta Lacks generally found the scientific aspects of the narrative most salient. 


\section{Sources}

In addition to frames offering insight into the meanings arising from coverage, the use of key sources in online content tells us about individuals and organizations linked to messages. In the classic diffusion literature, scholars argue that sources have the ability to frame messages and thus impart meanings through the selection of some interpretations over others. By framing Rebecca Skloot's book as a treatise on the exploitation of a poor African-American mother in the 1950s, some sources thus "set the frame" and created meanings associated with coverage. Oprah Winfrey and a forthcoming movie adaptation of the book were associated with much of the coverage, and the nature of Winfrey and her associates (Allan Ball and HBO Films) made salient the exploitation aspects of the book.

According to Rogers, these sources have the power to incite institutional change because their decisions can trigger a series of behavioral responses among other adopters. However, the current study explored Rogers' opinion leaders in a new context (online coverage) and found that it was not just the opinion leaders themselves who legitimized a message, but those individuals who mentioned the opinion leaders. Here, the opinion leaders take a somewhat passive role, as internet users cite them as sources to diffuse their own messages. In other words, internet users are more than followers of opinion leaders, internet users become conduits of information by exposing the message to networks beyond the information producer's network. 


\section{The Intersection of Frames and Sources}

Observing the intersection of frames and sources allowed me to see what role sources within a social network have on a salience transfer. To return to the literature, sources who have the ability to frame messages can decide what others perceive as important. Recall Foucault's argument, that this ability to decide what is important—to shape reality—confers a tremendous amount of power.

Therefore, what does the process of salience transfer look like on the internet, based on the current case study? According to the data, the process appears to be dynamic, episodic and constantly negotiated. For example, mentions of Oprah Winfrey, Alan Ball and HBO Films occur almost exclusively on May 12 and are rarely mentioned again in the subsequent key events. Here, it appears that source associations were tied to a series of smaller events that cycled throughout the main event of the book publicity campaign. This series of smaller events could have been necessary to maintaining momentum in coverage. The Google Alert map (the indexing of the key words "Henrietta Lacks" in the first six months of the book's release) also supports this episodic observation as there were dips in coverage preceding every major spike, and there were no plateaus or sustained trends in activity. The findings also indicate that well-known or powerful names were most likely to be associated with a diverse array of frames. Recall that it is not Oprah Winfrey or Alan Ball using exploitative or scientific frames themselves, but the internet users who produce content mentioning them as sources. For example, looking back at Figure 5, one can see that Winfrey has the farthest reach (that is, the highest frequency) and is associated with seven different frames. This pattern 
provides insight on the content creators who cited Winfrey as a source. The current study found that source mentions were more influential when there was a plurality of frames, and frames more influential when the source involved was not as well-known. In other words, it was less important how a content item was framed than who the content item mentioned—unless the sources were not seen as powerful (by Foucault's estimation). Examples include the Lacks family members and producers groups (recall this group comprises lesser known producers than Alan Ball, such as Kate Forte and Peter Macdissi) who were closely tied to the exploitation frame.

Because Oprah Winfrey and Alan Ball had a greater number of mentions, perhaps there was more opportunity for them to be associated with a greater number of frames. Yet, why did they garner so many mentions in the first place? The obvious answer is that they are more influential than those sources with fewer mentions. It appears that influential names have farther reach in diffusing information in social networks, because they have an audience "that will go to bat for them" to spread a message. This insight tells us that legitimacy is important on the internet, especially if you want your message to diffuse quickly. However, this observation adds a unique spin on diffusion theory, because it is not the opinion leaders themselves that are accelerating the spread of a message, but a legion of dedicated audience members, fans, or followers communicating on their behalf by aligning their messages with sources.

Coming full circle, recall that power is "spun through discourse" and that, to understand power, we should focus on the "materials" and "tactics" of power in discourse (Foucault, 1980). In the current study, these "materials" and "tactics" are the frames and 
sources associated with The Immortal Life of Henrietta Lacks. Together, frames and sources tell us a story about how messages gain traction online. Here, frames serve as an indicator of audience salience and sources accelerate the message by legitimizing content in a social network.

\section{Summary}

The current study fills a void in the literature by describing of the process of diffusion in the lifecycle of an online event through the lens of framing theory. The current study also attends to previously unanswered questions about salience in the context of the internet. Three key insights were gleaned, which I will discuss from a prescriptive perspective. First, if you want to set a message in motion online, frame the message in a format conducive to sharing among information consumers (who in turn, will become information producers if you succeed in salience transfer). Second, provoke coverage if online activity wanes: a series of smaller events can sustain the lifecycle of the larger event. For example, Rebecca Skloot was highly active in her book promotion activities (Kellogg, 2010). She tapped her professional networks, leveraged social media, and conducted a busy schedule of appearances all across the country. According to Rogers' diffusion theory, every promotional action Skloot took had the potential to reach an opinion leader of an expanded social network outside of her own. These appearances garnered attention from people within Oprah Winfrey's network an even Winfrey directly. For example, on Oprah.com, Winfrey was described as reading the book all in one sitting and that she "couldn't put the book down" (Oprah.com, 2010, n.p.). This leads 
us to the third insight: if you want a successful online campaign, align your message with an opinion leader. The followers, fans, and readers of that particular opinion leader (or source) will add traction to your campaign by the rapid sharing of your message throughout other social networks. However, this third step appears to have a major drawback, as evidenced in the findings - the greater the diffusion on behalf of a powerful source, the greater plurality of frames. This means that, unless you are someone like Oprah Winfrey who can "set a frame" in a mere mention, the farther the message spreads, the less control you have over how that message is framed. However, recall that framing becomes inconsequential after the message has been widely adopted (Kennedy \& Fiss, 2009). Therefore, a plurality of frames should be viewed as a step toward the institutionalization of a message, not necessarily a loss of control.

\section{Limitations}

An important limitation is the lack of guidance for this type of online research. At the onset of my study, few researchers had published empirical research about online coverage specifically pertaining to frames and diffusion, and I borrowed heavily from scholars who used such methods as "Google Alerts" to capture data. Therefore, I acknowledge a Google bias in the methodology. This means the current study relies on unpublicized, constantly changing search algorithms to generate a population of English language content.

A second weakness with Google Alerts the possibility of populating content that may not have anything to do with The Immortal Life of Henrietta Lacks. For example, an 
alert based on the key words "Henrietta Lacks" may actually read "Henrietta lacks the drive to earn decent grades." Recall the unknown frame category for content that could not be read for frames, which comprised nearly one quarter of the total frame data. In other words, nearly a quarter of the content items could not be read for frames because much of this material was spam, affiliate marketing, off-topic, expired, etc. This emergent category still tells us something: it tells us that there is a lot of chatter containing the key words "Henrietta Lacks." Though at times nonsensical, alert indexes indicate that individuals are searching for the words "Henrietta Lacks" and online marketers are using this to their advantage, by clustering advertising content with those key words to drive visitors to various sites, unrelated to the book. The prominence of the unknown category does not diminish the importance of frames in the current study, but rather bolsters the notion that the internet is an environment with ongoing negotiation and collaboration. The emphasis on the interpersonal, the fact that individual users remove or contribute information at any time (even to the detriment of those searching for relevant content), speaks volumes about the conversational aspect of the medium.

Most of the research to date has examined online frames descriptively. Diffusion researchers have examined the adoption of innovations or technology as an effect of the communication of information, while I was interested in examining the process of diffusion rather than its effects. My exploration into process was challenging: how does one sift through more than 3,000 web pages to make sense of the qualities of coverage? Therefore, I decided on a mixed-methodological approach, borrowing from qualitative and descriptive methods in addition to quantitative methods of cataloging the data, such 
as frames and sources. My hope is that I have captured some semblance of coverage through the category-creation, which is admittedly a somewhat rough approach to examining the data. But I also argue that by conducting a close reading of the content, I have fleshed out how meanings were constructed in frames and by sources.

I acknowledge that the use of the case study methods (Yin, 2002) has advantages and drawbacks. One of the strengths of this type of research is that it captures a snapshot of a larger phenomenon; particularly in an area where few have treaded before. One of the draw-backs of the mixed-method, single-case methodology is the lack of generalizability. Yin (2002) states that multi-case studies are stronger than single-case studies. However in situations where a single-case study is the only feasible option (such as pilot research) Yin (2002) stated that it can muster methodological rigor if it is well documented and the data were analyzed to the standards of the particular research paradigm.

From a quantitative perspective, this research lacks generalizability outside the context of the current case study (Babbie, 2008). I therefore acknowledge that my findings cannot be formally generalized to the context of the internet as a whole. However, I did fulfill the requirements of the single-case, mixed-method approach which allows me to attend to insights specific to how The Immortal Life of Henrietta Lacks diffused online.

My hope is that these findings lay the groundwork for future study particularly in how frames and sources interact in the diffusion of a message. Areas ripe for future study could include a more detailed snapshot on an event's publicity cycle by extending the 
time frame or comparing coverage to a second popular science book. Further research in this area may fill in gaps of understanding, particularly in how meaning is constructed in online social networks. 


\section{REFERENCES}

Ackland, R., Gibson, R., Lusoli, W. \& Ward, S. (2010). Engaging with the public? Assessing the online presence and communication practices of the nanotechnology industry. Social Science Computer Review 11 (28), pp. 443-465.

Appadurai, A. (1986). Introduction: Commodities and the Politics of Value, in The Social Life of Things: Commodities in Cultural Perspective, ed. Appadurai, A. Cambridge, Cambridge University Press, pp. 3-63.

Arsenault, D. Smith, L.D., and Beauchamp. E.A., (2006). Visual Inscriptions in the Scientific Hierarchy: Mapping the "Treasures of Science." Science Communication, 27(3), pp. 376-428.

Babbie, E. (2008). The Basics of Social Research. Cengage Learning.

Benson, R. (2006). News Media as a "Journalistic Field": What Bourdieu adds to new institutionalism, and vice versa. Political Communication. 23, pp. 187-202..

Brennan, R. L., \& Prediger, D. J. (1981). Coefficient Kappa: Some uses, misuses, and alternatives. Educational and Psychological Measurement (41), pp. 687-699.

Carey, J. (1995) 'The Press, Public Opinion, and Public Discourse', in T. Glasser and C.Salmon (eds.) Public Opinion and the Communication of Consent, pp. 373-402. New York: Guilford.

Chabot, S. (2004). Framing, Transnational Diffusion, and African-American Intellectuals in the Land of Gandhi. International Review of Social History. 49. pp 19-40. 
Culler, J. (1997). Literary Theory: A Very Short Introduction.

Oxford: Oxford University Press.

Cohen, B. C. (1963). "The press and foreign policy".

Princeton, NJ: Princeton University Press.

Cohen, J. (1960). A coefficient of agreement for nominal scales.

Educational and Psychological Measurement, 20(1), pp. 37-46.

Coleman, C.L., Hartley, H. and Kennamer J.D. (2006). Examining Claims makers'

Frames in News Coverage of Direct-to-Consumer Advertising.

Journalism and Mass Communication Quarterly. 83, pp. 547-63.

Coleman, C.L., and Dysart, E.V. (2005). Framing of Kennewick Man against the Backdrop of a Scientific and Cultural Controversy. Science Communication. 27(3). Sage Publications.

Costello, P. (2010). Will Henrietta Lacks now get her due?. Scope. Stanford School of Medicine. Retrieved April 23, 2010:

http://scopeblog.stanford.edu/2010/04/henrietta_lacks_case/

Covert, M. (2010). Rebecca Skloot's first book presents the immortal life of Henrietta Lacks and the debt we owe her. The Oregonian. Retrieved March 29, 2010: http://www.oregonlive.com/books/index.ssf/2010/02/the_immortal_life_ of_henrietta.html

Creswell, J., and Plano Clark, V.L., (2006) Designing and conducting mixed methods research. Thousand Oaks: Sage Publications.

Curtis, A. (1997). The Way of the Flesh. BBC Films. 
Davenport, E. \& Cronin, B. (2000). The citation network as a prototype for representing trust in virtual environments. Monograph Series. pp. 517-534.

Davidson, W. (1954). Probing the secret of life. Colliers. pp. 78-83.

Dearing, J. (2009). Applying Diffusion of Innovation Theory to Intervention Development. Research on Social Work Practice. 19(9), pp. 503-518.

Dearing, J. W., \& Rogers, E. M. (1996). Agenda-setting. Thousand Oaks, CA: Sage.

Dickinson, W. B., Hines, C. V., \& Onwuegbuzie, A. J. (2006). Graphical analysis of clandestine methamphetamine laboratories utilizing PROC GMAP: A visual inventory of activity across the United States. Proceedings of the Thirty-first SAS Users Group International Conference (Paper 136-31). Cary, NC: SAS Institute. Retrieved, from http://www2.sas.com/proceedings/sugi31/136-31.pdf

Disclose t.v. (2011). About Us. Retrieved July 8, 2011:

http://www.disclose.tv/action/static/about/

Earl, J. (2006) 'Pursuing Social Change Online: The Use of Four Protest Tactics on the Internet', Social Science Computer Review 24(3), pp. 362-77.

Entman, R. (1993). Framing: Toward clarification of a fractured paradigm. Journal of Communication, 43(4), pp. 51-58.

Esser, F., and D'Angelo P., (2003) Framing the Press and Publicity Process in U.S., British, and German General Election Campaigns: A Comparative Study of Metacoverage. International Journal of Press/Politics. 11(3), pp. 44-66. Thousand Oaks: Sage Publications.

Flanagin, A., Flanagin, C., and Flanagin, J. (2009). Technical code and the social 
construction of the internet. New Media and Society, 11(8). pp. 1-19.

Fleiss, J.L. (1981). Statistical methods for rates and proportions (2nd ed.).

New York: John Wiley.

Fraser, N. (1992) 'Rethinking the Public Sphere: A Contribution to the Critique of Actually Existing Democracy', in C. Calhoun (ed.) Habermas and the Public Sphere, pp. 109-42. Cambridge, MA: MIT Press.

Freeman, L.C. and Webster C.M. (1994). Interpersonal proximity in social and cognitive space. Social Cognition. 12(3). pp. 223-247.

Foucault, M., (1977). Discipline and Punish. The Birth of the Prison, London: Penguin Books.

Foucault, M., (1980). Power/Knowledge: Selected Interviews and Other Writings, 1972-1977. Hetfordshire: Harvester Press.

Gamson, W. A., \& Meyer, D. S. (1996). Framing political opportunity. In D. McAdam, J. D. McCarthy, \& M. N.Zald (Eds.), Comparative perspectives on social Movements. pp. 275-290. New York: Cambridge University Press.

Grady, J. (2006). Edward Tufte and the Promise of a Visual Social Science. In Visual Cultures of Science: Rethinking Representational Practices in Knowledge Building and Science Communication. Hanover and London: Dartmouth College Press.

Green, S. (2004). A rhetorical theory of diffusion. Academy of Management Review. 29. pp 653-669.

Green, S. E., Li, Y., \& Nohria, N. (2009). Suspended in self-spun webs of significance: 
Conceptualizing institutionalization as change in argument structure. Academy of Management Journal. 52. pp 11-36.

Guidarini, L. (2010). Recently Borrowed from My Library. Bluestalking:

Editor at Large of Her Own Life. Retrieved February 16, 2010:

http://bluestalking.typepad.com/the_bluestalking_reader/2010/02/recentlyborrowed-from-my-library.html

Habermas, J. (1962). The Structural Transformation of the Public Sphere: An Inquiry into a category of Bourgeois Society. Cambridge: Polity.

Harris Online (2010). Best Sellers By Area. Harris Online. Retrieved March 28, 2010: http://harrisonline.blogspot.com/2010/03/best-sellers-by-area.html

Halbwachs, M. (1992). On collective memory. Chicago: The University of Chicago Press.

Hunt, L. (2010). The Immortal Life of Henrietta Lacks: a bittersweet legacy. The U.K. Telegraph. Retrieved June 21, 2010: http://www.telegraph.co.uk/science/7845119/The-Immortal-Life-ofHenrietta-Lacks-a-bittersweet-legacy.html

Hunter, C.K. (2010). “God's Final Judgment of Mankind” Disclose.tv. Retrieved March 29, 2010: http://www.disclose.tv/forum/hmm-wonder-what-s-nextt19102.html

Jacobs, J, (1961) The Death and Life of Great American Cities. New York: Random House.

Johnson, Steven (2003).Google's Memory Upgrade: How Blogger could do more than improve Google's Web searches. Slate. Retrieved October 10, 2011: 
http://www.slate.com/articles/technology/webhead/2003/03/googles_memory_up grade.html

Jones, H.W., McKusick, V.A., Harper, P.S., and Wuu, K.D. (1971). George Otto Gey. (1899-1970). The HeLa cell and a reappraisal of its origin.

Obstetrics and gynecology 38(6), pp. 945-9.

Kaid, L. L., \& Wadsworth, A. J. (1989). Content Analysis. In Philip Emmert and Larry L. Barker (Eds.), Measurement of communication behavior. pp. 197-217. New York: Longman.

Kellogg, C. (2010). Henrietta Lacks' 'Immortal' roots: science journalist Rebecca Skloot looks at the woman behind the first human cell line and her unwitting scientific legacy. Los Angeles Times. Retrieved: June 1, 2010:

http://articles.latimes.com/2010/feb/08/entertainment/la-et-rebecca-skloot82010feb08/3

Kennedy, M.T., and Fiss, P.C. (2009). Institutionalization, Framing and Diffusion: The logic of TQM adoption and implementation decisions among U.S. hospitals. Academy of Management Journal. 52(5). pp 879-918.

Kleinberg, J. M. (1999). Authoritative sources in a hyperlinked environment, Journal of the ACM (JACM).42(5).

Lacy, S., \& Riffe, D. (1996). Sampling error and selecting intercoder reliability samples for nominal content categories: Sins of omission and commission in mass communication quantitative research. Journalism \& Mass Communication Quarterly, 73, pp. 969-973. 
Landis, J.R.; \& Koch, G.G. (1977). “The measurement of observer agreement for categorical data". Biometrics. 33(1), pp. 159-174.

Leal-Anaya, J. (2010). Ramtha: Immortal Cells, Cancer and the Telomeres. Ramtha's School of Enlightenment Newsletter. Retrieved April 21, 2010: http://www.rse-newsletter.com/2010/04/ramtha-immortal-cells-cancer-and-thetelomeres/

Levinson, P. (2009) New New Media. Boston: Penguin Academics.

Lindlof, T.R., and Taylor, B.C. (2002). Qualitative Communication Research Methods. Thousand Oaks: Sage.

Lippmann, W. (1922). The world outside and the pictures in our heads. Public opinion. pp. 3-32. New York: Harcourt, Brace and Company.

Littleton, C. (2010). Ball, Winfrey partner on 'Life': Pair will produce HBO pic via Harpo. Variety. Retrieved: May, 122010. http://www.variety.com/article/VR1118019154?refCatId=14

Lividity. (2010). True Blood's Alan Ball teams up with Oprah Winfrey. True Blood News: The Place to Feed Your Obsession. Retrieved May 12, 2010: http://www.trueblood-news.com/true-bloods-alan-ball-teams-up-with-oprahwinfrey

Lock, M. (2001). The Alienation of Body Tissue and the Biopolitics of Immortalized Cell Lines. Body and Society. 7(2-3), pp. 63-91. London: Sage Publications.

Lynch, M. (2006). The Production of Images Vision and Revision in the History, Philosophy, and Sociology of Science. In Visual Cultures of Science: Rethinking 
Representational Practices in Knowledge Building and Science Communication (pp. 26-39). Hanover and London: Dartmouth College Press.

Martin, C.R., (2003). The 1997 United Parcel Service Strike: Framing the Story for Popular Consumption. The Journal of Communication Inquiry. 27(2) pp. 190-210. Thousand Oaks: Sage Publications.

McCombs, M.E. and Shaw, D.L. (1972). The Agenda-Setting Function of Mass Media. Public Opinion Quarterly. 36 (2), pp. 176-187.

Meraz, S., (2011). The fight for 'how to think': Traditional media, social networks, and issue interpretation. Journalism. 12 (1), pp. 102-127.

Miles, M.B., and Huberman, A.M. (1994). Qualitative Data Analysis. Thousand Oaks: Sage.

Molotch, H., and Lester, M. (1975). Accidental news: The great oil spill as local occurrence and national event. The American Journal of Sociology, 82(2), pp. 235-260.

Mozilla (2011). The Mozilla Manifesto. Retrieved: September 10, 2011. http://www.mozilla.org/about/manifesto.en.html

Neuendorf, K.A. (2002). The content analysis guidebook. Sage.

Nisbet, M., Brossard, D. \& Kroepsch A. (2003). Framing Science: The stem cell controversy in an age of press/politics. The International Journal of Press/Politics. 18(36).

Nisbet, M. \& Mooney, C. (2007). Framing Science. Science. 316 (56). American Association for the Advancement of Science. 
Oprah.com. (2010). Harpo Films, Alan Ball and HBO Team Up for The Immortal Life of Henrietta Lacks. Oprah.com. Retrieved May 12, 2010: http://www.oprah.com/pressroom/Harpo-Films-Alan-Ball-and-HBO-TheImmortal-Life-of-Henrietta-Lacks

Onwuegbuzie, A.J., Dickinson, W.B., (2008). and Mixed Methods Analysis and Information Visualization: Graphical Display for Effective Communication of Research. The Qualitative Report. 13(2) pp. 204-225.

Papacharissi, Z. (2002). The virtual sphere: The internet as a public sphere. New Media \& Society. 4(1). pp. 9-27. Sage.

Postill, J. (2008). Localizing the internet beyond communities and networks. New Media \& Society. 6(10) pp. 413-431.

Price, V., Tewsksbury, D., \& Powers, E. (1997). Switching trains of thought: The impact of news frames on readers' cognitive responses. Communication Research. (24) pp. 481-506.

Putnam, R.D. (1996). The strange disappearance of civic America. The American Prospect 24(1), pp. 34-48.

Randolph, J. J. (2005). Free-marginal multirater kappa: An alternative to Fleiss' fixed-marginal multirater kappa. Paper presented at the Joensuи University Learning and Instruction Symposium 2005, Joensuu, Finland, October 14-15th, 2005.

Randolph, J. J. (2008). Online Kappa Calculator. Retrieved May 4, 2011, retrieved from http://justus.randolph.name/kappa 
Reardon, R. (2010). ASFA AP Biol, Week 30: Bleeding out, Neurologically Speaking. ASFA AP Biology: Big ideas and tight junctions. Retrieved March 29, 2010: http://asfaapbio.wordpress.com/2010/03/29/asfa-ap-biol-week-30-bleeding-outneurologically-speaking/

Rogers, M. (1976). “The Double-Edged Helix” Rolling Stone. (29).

Rogers, E.M. (1995). Diffusion of innovations. New York: Simon and Schuster.

Russell, N. (2009). The New Men: Scientists at Work in Popular British Fiction Between the Early 1930s and the Late 1960s. Science Communication. 31(1), pp. 29-56.

Schuler, D. (2004). Shaping the network society: The new role of civil society in cyberspace.

Schudson, M. (1997). Why conversation is not the soul of democracy. Critical Studies in Mass Communication. 14(4), pp. 1-13.

Skloot, R. (2010a). The Immortal Life of Henrietta Lacks. New York: Crown Publishers.

Skloot, R. (2010b). The Immortal Life of Henrietta Lacks Book Tour Trailer Part 1. Culture Dish. Retrieved March 29, 2010:http://scienceblogs.com/culturedish/ 2010/03/the_immortal_life_of_henrietta_3.php

Skloot, R. (2010c). Oprah.com Recommends The Immortal Life of Henrietta Lacks as an Ideal Mothers Day Gift. Rebecca Skloot: Journalist, Teacher, Author of The Immortal Life of Henrietta Lacks. Retrieved May 12, 2010: http://rebeccaskloot.com/2010/05/oprah-com-recommends-the-immortal-life-ofhenrietta-lacks-as-an-ideal-mothers-day-gift/

Siegel, S., \& Castellan, (1988). Nonparametric statistics for the social sciences, 
(2nd ed.). New York: McGraw-Hill.

Snow, D., Rochford, E. B. J., Worden, S. K., \& Benford, R. D. (1986). Frame alignment processes, micromobilization, and movement participation*. American Sociological Review, 51, 464-481.

Strauss A. \& Corbin J. (1990). Basics of Qualitative Research: Grounded Theory Procedures and Techniques. Newbury Park: Sage Publications.

Stromer-Galley, J., \& Martey, R. M. (2009). Visual spaces, norm governed places: The influence of spatial context online. New Media \& Society, 11, pp. 1041-1060. Suddaby, R., \& Greenwood, R. (2005). Rhetorical strategies of legitimacy. Administrative Science Quarterly. 50. pp 35-67.

Tashakkori, A., \& Teddlie, C. (1998). Mixed methodology: Combining qualitative and quantitative approaches. Thousand Oaks, CA; Sage.

Thomas, S.B. and Crouse Quinn, S. (2000). Light on the Shadow of the Syphilis Study at Tuskegee. Health Promotion Practice. (1), pp. 234-237.

Tankard, J. W. (2001). The empirical approach to the study of media framing . In S. D. Reese, O. H. Gandy \& A. E. Grant (Eds.), Framing public life: Perspectives on media and our understanding of the social world (illustrated ed., pp. 95-105) Taylor \& Francis.

Tuchman, G. (1978). News as a constructed reality. Making news: A study in the construction of reality. pp. 182-197. New York: The Free Press.

Trumbo, J. (2000) Essay: Seeing Science: Research Opportunities in the Visual Communication of Science. Science Communication, 21, pp. 379-391. 
Tufte, E. R. (2006). Beautiful evidence. Cheshire, CT: Graphics Press.

Ungar, S. (2008). Global Bird Flu Communication: Hot Crisis and Media Reassurance. Science Communication. 29(4), pp. 472-497.

Warrens, M. J. (2010). Inequalities between multi-rater kappas. Advances in Data Analysis and Classification.

Wallsten, K. (2010).“Yes We Can”: How Online Viewership, Blog Discussion, Campaign Statements, and Mainstream Media Coverage Produced a Viral Video Phenomenon. Journal of Information Technology \& Politics. 7 (2-3).

Wimmer, R. D. \& Dominick, J.R. (1997): Mass Media Research: An Introduction. Belmont, MA: Wadsworth.

Yin, R.K. (2009). Case study research: design and methods. Applied social research methods series. 5(4). Sage.

Zillmann, D., Chen, L., Knobloch, S., \& Callison, C. (2004). Effects of lead framing on selective exposure to internet news reports. Communication Research, 31, pp. 58-81. 


\section{APPENDIX A}

COMPREHENSIVE LIST OF SOURCES

\begin{tabular}{|c|c|c|c|c|c|c|c|}
\hline \multirow[t]{2}{*}{ Source } & \multicolumn{6}{|c|}{ Key Event Date } & \multirow[t]{2}{*}{ Total } \\
\hline & $2 / 16$ & $3 / 29$ & $4 / 22$ & $5 / 12$ & $6 / 21$ & $7 / 21$ & \\
\hline Adam Curtis & & & & & 1 & 1 & 2 \\
\hline Alan Ball & & & & 24 & & & 24 \\
\hline Alok Jha & & & & & 7 & & 7 \\
\hline Amazon & 3 & & & & 1 & 1 & 5 \\
\hline Arizona State & & & 2 & & & & 2 \\
\hline Barack Obama & & & & & 1 & & 1 \\
\hline Bobbette Lacks & 1 & & & & & & 1 \\
\hline Catlin Gabel & & & 1 & & & & 1 \\
\hline CBS Sunday Morning & & & & & & 1 & 1 \\
\hline Chico State & & & 1 & & & & 1 \\
\hline Columbia University & 1 & & & & & & 1 \\
\hline David Kroll & & & & & 1 & & 1 \\
\hline David Prete & & 4 & & & 1 & & 5 \\
\hline Dawn Littleton (Dr.) & & & 1 & & & & 1 \\
\hline $\begin{array}{l}\text { Deborah Cameron/ABC } \\
\text { Sydney (radio show) }\end{array}$ & & & & 1 & & & 1 \\
\hline Deborah Lacks & & & 1 & & 1 & & 2 \\
\hline Dr. Amy Harmon (Dr.) & & & 1 & & & & 1 \\
\hline Dwight Garner & 1 & & & & & & 1 \\
\hline Eddie Greene (Dr.) & & & 1 & & & & 1 \\
\hline Floyd Skloot & & & & 1 & & & 1 \\
\hline Frankenstein & & 1 & & & & & 1 \\
\hline Franklin Roosevelt & & & & & 1 & & 1 \\
\hline Fried Green Tomatoes & & & & & 1 & & 1 \\
\hline Fritzi Bodenheimer & & & & & & 5 & 5 \\
\hline Gail Javitt & & & & & 2 & & 2 \\
\hline
\end{tabular}




\begin{tabular}{|c|c|c|c|c|c|c|c|}
\hline Gary Lacks & 1 & & & & & & 1 \\
\hline George Gey (Dr.) & 2 & & & & 1 & 1 & 4 \\
\hline Hank Greely (J.D.) & & & 1 & & & & 1 \\
\hline Harald zur Hausen & & & & & 1 & & 1 \\
\hline $\begin{array}{l}\text { Harriet Washington's } \\
\text { Medical Apartheid }\end{array}$ & 1 & & & & & & 1 \\
\hline Havasupai Indian Tribe & & & 2 & & & & 2 \\
\hline HBO Films & & & & 19 & & & 19 \\
\hline Hurricane (movie) & & & & & 1 & & 1 \\
\hline Jad Abumrad (Radiolab) & & & & & 1 & & 1 \\
\hline Jesus Banch, Biologist & & & 1 & & & & 1 \\
\hline John Moore & 1 & & & & 2 & & 3 \\
\hline Jon Cooper (Dr.) & & & 1 & & & & 1 \\
\hline Kate Forte & & & & 2 & & & 2 \\
\hline $\begin{array}{l}\text { Kiki Sanford (Dr. Kiki's } \\
\text { Science Hour) }\end{array}$ & & & 1 & & & & 1 \\
\hline LA Times & & & & & 1 & & 1 \\
\hline Lacks Family & & 1 & & & & & 1 \\
\hline Lee Hartwell (Dr.) & & & 1 & & & & 1 \\
\hline Lisa Margonelli (Dr.) & & & 1 & & & & 1 \\
\hline Liz Hunt (UK Telegraph) & & & & & 3 & & 3 \\
\hline MacMillan & & & & & 1 & & 1 \\
\hline $\begin{array}{l}\text { Maggie Koerth-Baker } \\
\text { (BoingBoing) }\end{array}$ & & 1 & & & & & 1 \\
\hline Mayo Clinic & & & 1 & & & & 1 \\
\hline New York Times & 1 & & 1 & & 3 & & 5 \\
\hline $\begin{array}{l}\text { Newport News Public } \\
\text { Library }\end{array}$ & & & & 1 & & & 1 \\
\hline Nieman Storyboard & & & & & & 1 & 1 \\
\hline $\begin{array}{l}\text { Not Exactly Rocket } \\
\text { Science }\end{array}$ & 1 & & & & & & 1 \\
\hline NPR (Fresh Air) & 1 & & 1 & & & & 2 \\
\hline Oprah Winfrey & & & & 30 & 2 & & 32 \\
\hline Peter Macdissi & & & & 2 & & & 2 \\
\hline $\begin{array}{l}\text { Ramtha School of } \\
\text { Enlightenment }\end{array}$ & & & 1 & & & & 1 \\
\hline
\end{tabular}




\begin{tabular}{|c|c|c|c|c|c|c|c|}
\hline $\begin{array}{l}\text { Richard Wesley TeLinde } \\
\text { (Dr.) }\end{array}$ & & & & & 1 & & 1 \\
\hline Science Journal & & & 1 & & & & 1 \\
\hline Scienceblogs & & 1 & & & & & 1 \\
\hline $\begin{array}{l}\text { Sir Lord Keenan Kester } \\
\text { Cofield }\end{array}$ & 1 & & & & & & 1 \\
\hline Smithsonian Magazine & & & & & 1 & & 1 \\
\hline Stephen Colbert & & 1 & 1 & 1 & & & 3 \\
\hline Steve Ember & & & & & & 5 & 5 \\
\hline Steven Berlin Johnson & & & & & 1 & & 1 \\
\hline TED Talks & & & 1 & & & & 1 \\
\hline The Chicago Tribune & 1 & 1 & & & & & 1 \\
\hline The Independent & 1 & & & & & & 1 \\
\hline Therese Markow (Dr.) & & & 1 & & & & 1 \\
\hline U Cal at San Diego & & & 1 & & & & 1 \\
\hline $\begin{array}{l}\text { UIC Urban Allied Health } \\
\text { Academy Spring } 2010 \\
\text { Book Group }\end{array}$ & 1 & & & & & & 1 \\
\hline Variety & & & & 1 & & & 1 \\
\hline Vincent Racaniello (Prof) & 1 & & & & & & 1 \\
\hline Wall Street Journal & 1 & & & & 1 & 5 & 7 \\
\hline Washington Post & & & & 1 & & & 1 \\
\hline Waterhouse & & & & & 1 & & 1 \\
\hline WHYY's Radio Times & 2 & & & & & & 2 \\
\hline Wikipedia & & & 1 & & & & 1 \\
\hline William Scherer (Dr.) & & & & & 1 & & 1 \\
\hline Wired Magazine & & & 1 & & & & 1 \\
\hline Total & 22 & 9 & 27 & 84 & 39 & 20 & 201 \\
\hline
\end{tabular}




\section{APPENDIX B}

\section{CODING PACKET}

\section{Diffusion of Scientific Frames Online: Codesheet}

OVERVIEW, This packet will include web pages randomly selected from my data and their Google alerts I am investigating the manner in which scientific controversy unfolds on the internet. This exercise is meant check the reliability of my coding skills. I am asking you to look for the most dominant frame in web page content and if present, the source. A frame is the essence of a story or the "take-away" item in the reporting of an event. A source is not the author of the web page content, but the person or organization mention, quoted or linked to in the web page content.

The framing categories are designed to be mutually exclusive, so there should be one frame noted per web page. I understand that this could be a difficult task narrowing down to the most dominant frame, so I have some helpful hints in terms of strategy.

To begin, the phrases "poor black mother" and "cells taken without her permission are so profound in frequency, they become the story as opposed to a way to frame the story by achieving a sort of sound-bite-like status. These phrases are on the cover of the book and in the press releases, consequently they dominate the discussion of the book. For this reason, please pay special attention to the dominant frames other than these, assuming these phrases will appear over and over again. Furthermore, the manner in which individuals introduce the book is almost formulaic, a brief mention of "poor blackmother," a slew of scientific breakthroughs and dosing with the current plight of the Lacks family. To discem a frame you almost have to set that spiel aside in order to see the real frames bubbling below the surface. For example, a blogger wrote introduced her post in a typical "poor black mother" fashion, but broke out of the stock prose to lament that she didn't pay attention in her high school science class, and how the stuff is really interesting, landing the web page content in the science category as opposed to the exploitation category

WHAT TO LOOK FOR. When reading the web pages in the following packet please note two things

$$
\begin{aligned}
& \text { 1) Framing Category } \\
& \text { 2) Source (when applicable) }
\end{aligned}
$$

Examples of framing categories and source identification will be included on the following page. Recall that a source is not the same as an author. A source is in this sense is an individual or organization that the information is attributed to by either a quote, hyperlink, or mention in the text. For example a blogger may write: "Today I finished reading The Immortal Life of Henrietta Lacks. I initially heard of the book when I was listening to Terry Gross on Fresh Air." As a coder, you could write down Terry Gross/Fresh Air, or NPR in the category next to the frame on the coding sheet. Also, recall that unlike the framing categories which there can only be one per web page
You may be wondering where to look for a frame. When analyzed the data I found that for news sites the dominant frame was typically in the lede/beginning (a classic inverted-pyramid approach.) On social sites and blogging sites the dominan frame was either in a block quote, tag choice for the content, and typically bloggers saved their most poignant thoughts on The Inmortal Life of Henrietta Lacks towards the end of the content (narrative story telling style.)

If youre stumped because there is a lack of anecdotal insight or obvious spin on the web page content, $\mathrm{Id}$ note the absence or emphas is of one of the three components in the stock approach rd put "poor black mother" or information focusing on the Lacks family into the exploitation category, HeLabreakthroughs in the science category and big questions such as health care reform or genetic ownership in the ethics category. A noticeable exploitation/science/ethics pattern emerges in the data, so the emphasis or omission of one of these elements can dictate what category to note

Lastly, due to the nature of the medium, some of the data was expired, moved, or behind a privacy wall. However, the Google Alerts still contain a preview of the content, so Pd use that data when appropriate, For example, an alert captures that someone posted The Immortal Life of Henrietia Lacks as a book that they were currently reading via a Google Blogger widget. A new book was up on their current page, but it's a safe assumption to put the web page in the book listing category based on the alert summary. Other alert summaries may not be as informative and so that web page content should be put in the "no content" category. This technique may not be appropriate for all categories or link previews, so you use your best judgement when unsure

Thank you very much for your time. This is an important part of $m y$ research an I sincerely appreciate your help. I am available at any time for questions. I can be reached at 402-250-3213 or shavlikgyahoo.com

(because you're looking for the dominari frame) you can writ down as many sources that you find within a single web page. The source doesnt have to be a famous media person, the source may be a colleague or a $\mathrm{PhD}$ who works at a research hospital, or a next door neighbor, basically anyone mentioned by name. No need to list sources if the page is in the "no content" category.

Organizations mentioned by name also qualify as sources. For example: A book reviewer may write: "The Innortal Life of Hewrietta Lacks was on the New York Times best seller list seven times." At that point youd write "New York Times" in the source categor $y$. However, if you stumble across a New York Times Online page, do not simply write "New York Times" in the source category, write any name or organizations that may appear in the article. In this case the New York Times is not source in and of itself. Finally, there is no need to notate source references to author, Rebecca Skloot, it's understood that sh 


\section{Frame Categories:}

EXPLOITATION - this is a category with racial issues assumed (i.e. "poor black mother") and focuses on the marginalized or vulnerable in reference to web page content. For example emphasis on 'her children never knew... any mention of Tuskegee, $c$ r overt emphasis on the Lacks family, poverty, race, or gender

SCIENCE - typically a laundry list of breakthrough research that utilized Hela celk, for example, in-vitro technology, the polio

vaccine, S.TI. treatment, and cancer advances with a noticeable absence or minimization of biographical information regarding Henrietta Lacks when it is the dominant frame

ETHICS - content that specifically addresses medical ethics particularly in reference to professional practice, informed consent HIPPA, genetic ownership or health care reform. This category does not focus solely on the exploitation of vulnerable individuals but is a more prescriptive approach for a professional code of conduct $a$ a call for a change in policy.

PHILOSOPHICAL OR ABSTRACT - this category is for the contemplative, phibsophical $\propto$ abstract content. It can be expressions of gatitude $c$ religicsity or It can imply that the cells have some sense of agency. Often takes the form of discussing Henrietta Lacks cancer cells as if they were her (as a person) for example: Frankenstein anaboges and phrases such as "she's a mother to all of us "she's an angel "they shot ber into space" "they injected her with AIDS

LISTS - cases where the title The Inmortal Lufe of Henrletta Lacks is listed with no other content related to the book. This categcr is not limited to best seller lists, bit torrents, retail lists and library lists but also blog postings such as widgets that display "what I'm reading" - though lacking in word count this is still a significan frame because it captures the conversational aspect of the book's diffusion.
BOOK PUBLICITY - This categary has two approaches: PR activity from the author that offers no more than the standard summary of the book, if present at all, examples include autbor speaking engagements pertaining to The Immortal Life of Henrietta Lacks, excerpts from the book without any editorializing and second, obvicus plugsirecommendations from the individuals other than author with the "go out and buy this book' approach.

REBECCA SKLOOT - this category is restricted to biographical or professional information about the author For example: "Rebecca Skboot is a science writer and author of The Immortal Life of Henrietta Lacks.

SOCIAL READING - this categary is for book clubs, or reading initiatives with an emphasis on communal discussion, message boerd queries, Craigslist's discussicns, etc. Ex: poetry, black history month, solidarity, homework questions. Basically discussions not so much about the book, but about the people reading the book.

NO CONTENT - spam, 404 re-directs, server emors, expired content, blocked content, pages not in English $\propto$ alerts ctherwise unable to analyze for frames. These links are still an important part of the data because, for example, spammers $c$ affiliate marketers may put links in unrelated sites out of a response to users searching the phrase, "Henrietta Lacks" - therefore, these pages are still reflective of discourse and general public interest.

OTHER - use this category when the web page does not fit any of the categories above. Use this only ar a last-case scenario if you cant determine a frame. 


\title{
Examples:
}

\section{Exploitation}

\author{
Alert: \\ Google News Alert for: Henrietta Lacks \\ Henrietta Lacks died in 1951 . but her cells are still the basis for medical .... \\ Patriot-News \\ Earl Wilbourn of Susquehanna Township once tried to visit the grave of his long-dead \\ third cousin, Henrietta Lacks, but couldn't find it because it had no ... \\ See all stories on this topic
}

\section{Link:}

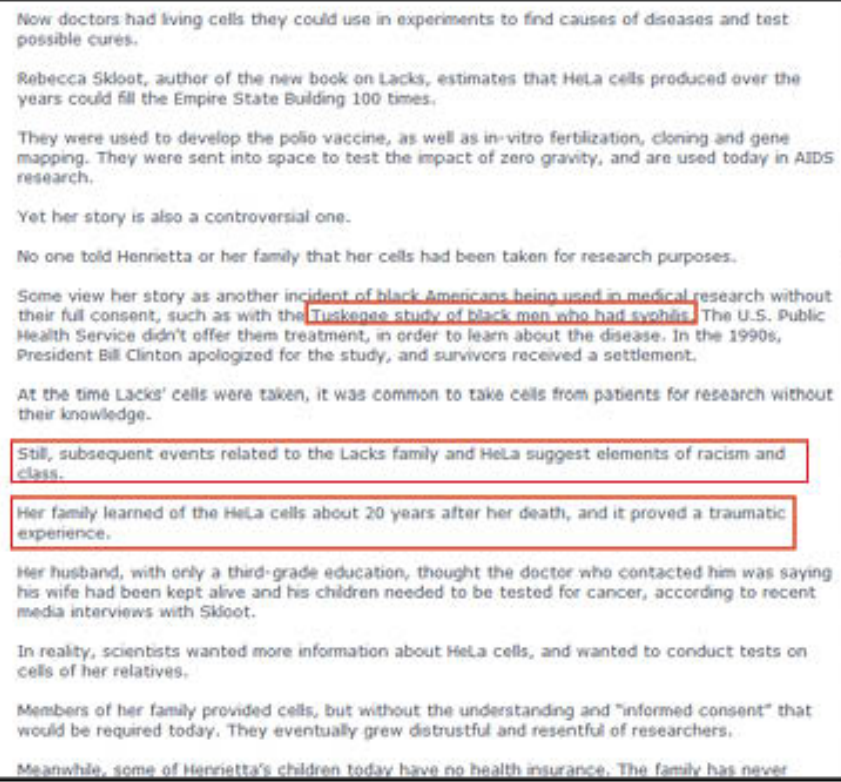

Rebecca Skbot, auther of the new book on Lacks, estimates that HeLa cells produced over the years could fill the Empire State Bulding 100 times.

They were used to develop the polio vaccine, as well as in.vitro fertization, cloning and gene mapping. They were sent into space to test the impact of zero gravity, and are used today in AIDS research.

Yet her story is also a controversial one.

No one told Henvietta or her family that her cells had been taken for research purposes.

Scme view her story as another incident of black-Americans heino wsed in medical 4 esearch without

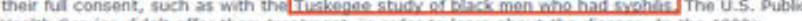

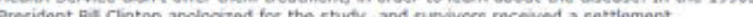

At the time Lacks' cells were taken, it was common to take cels trom patients for research without their knowledge.

Still, subsequent events related to the Lacks family and Hela suggest elements of racism and

Selass.

Her family learned of the Hela cells about 20 years after her death, and it proved a traumatic experience.

Mer husband, with only a third-grade education, thought the doctor who contacted him was saying his wife had been kept alve and his chldren needed to be tested for cancer, according to rocent. meda interviews with sisoot.

In realty, scientists wanted more information about Hela cells, and wantod to conduct tests on cells of her relatives.

Menbers of her family provided celts, but without the understanding and "informed consent" that would be required today. They eventually grew distrustful and resentful of researchers.

Meanwhle, some of Hesciatta's children today have no health insuranse. The family has newe

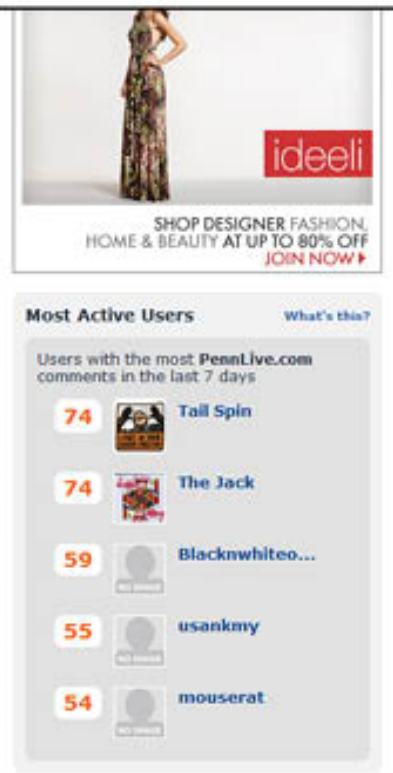




\section{Examples:}

\section{Science}

Alert:

Google Web Alert for: Henrietta Lacks

Book Review The Immortal Life of Hienrietta Lacks Laelaps

Though it has nothing at all to do with fossils or evolution Rebecca Skloot's The Immortal Life of

Henrietta Lacks is also a tale of contingency In February ...

\section{Link:}

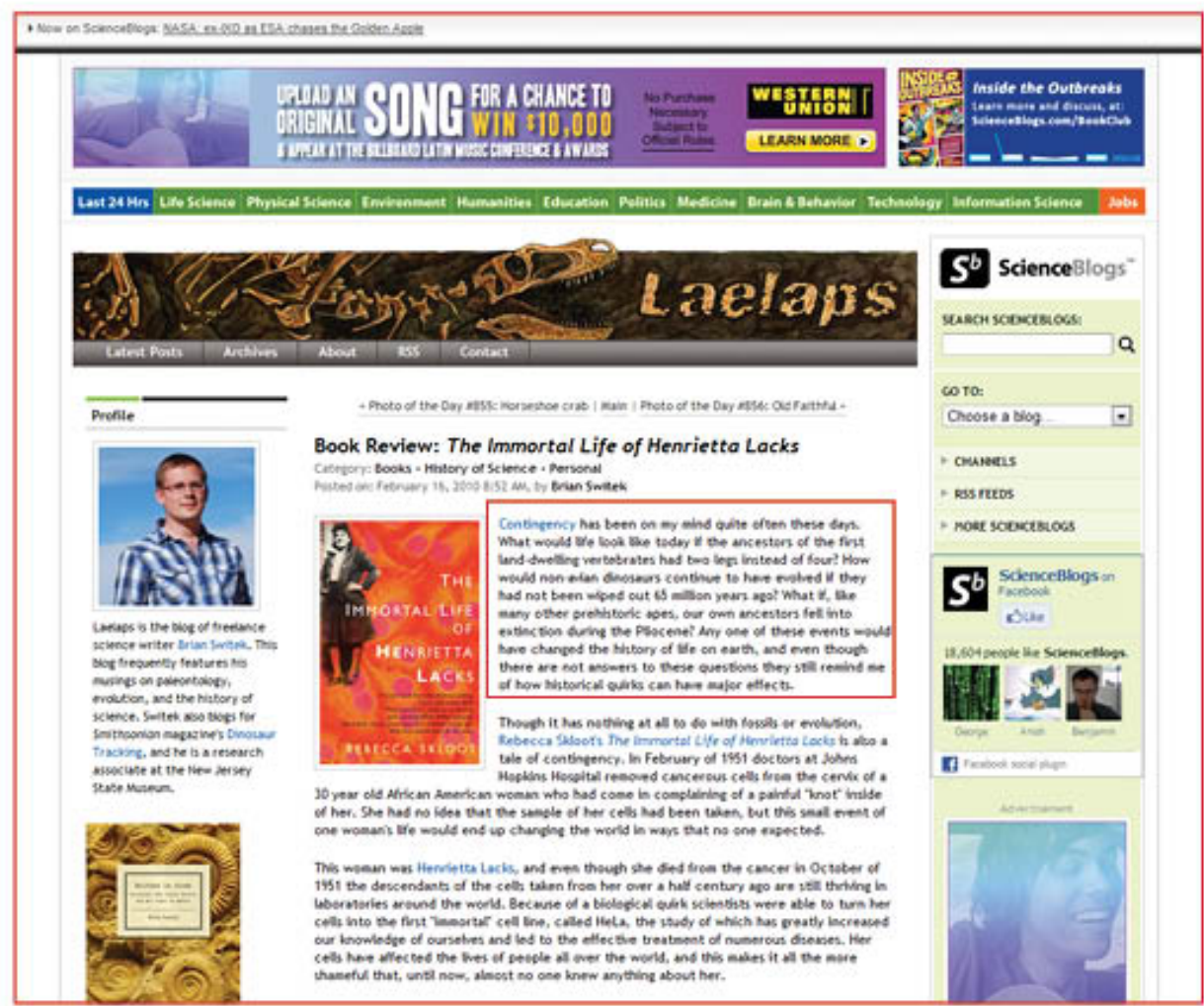




\section{Examples:}

\section{Ethics}

\section{Alert:}

Google News Alert for: Henrietta Lacks

Berman Institute Scholar Calls for a New Legal."Eithical Framework for Research.m.

AScribe (press release)

Reflections on 'The Immertal Life- of Henrietta Lacks' and the Status of Participants in Research Using

Human Specimens," Gail Javitt, JD, MPH,...

See all stories on thistoric

\section{Link:}

\section{AScribe}

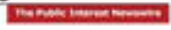

Mon Jun 210948232010 Pacific Time

Berman Institute Scholar Calls for a New Legal, Ethical Framework for Research With Human Tissue Specimens

BALTMORE, June 21 (AScnbe Newswire) - A lawyer and reseaccher at the Johns Hopkins Berman Insthte of Bioethics says a new legal and ethical framework needs to be placed around the donation and banking of human biological material, one that would more charty define the terms of the material's use - and address donor expectations before research begns.

In a new law review attice, 'Why Not Take All or Me? Refections on 'The immonal Life of Henrietta Lacks' and the Status of Partioparts in Research Using Human Specimens." "Gail Jewit, J.D., M.P. uses the slory of a woman whose cancerous cells revolutionized medcal research as the launching poirt for an exploration of the flass in the currert legal approach to the use of human specimens in research.

The Immotal Life of Herrietta Lacks, "by science joumalst Rebecca Skboc, has sloked pubic irterest in the etrical oblgations owed to tissue cortmbutors. Javitt sars the "story is a powerful reminder that, behind every tissue sample in a laboratory, is the person it came from"

Recertly, Sklock announced that her book will be adapted and turned into a cable-television move. Javitt applauds moving the discussion of these issues into the pubic form As she wethes, By teling the Lacks familys story in such an ergaging, accessible way, SWoot has moved the discussion
beyond the nartow cocfines of courtrooms and academia and into the pubic domain, where al those with a stake in the anowers can participate.

Published in the Minescla Journal of Law, Science and Technology, Jwart's article reponts that human tissue and DNh are increasingly being colected and used in reseatch Yet they are obtained and stored under a pasctwork of policies . some broad, some spectic. that Gictase how they may or may not be used in the tuture. Mary in the legal and scierbific arenas say tris is because federal and case law have falen behind modern reseach demands and tectniques

The federal human subject protection law known as the "Common Rude" requires irformed consert be obtained from participants in al federaty funsed research, and that includes tissue research. However, 1 identiding information has been removed, the law doesm apply

Even where infomed consent is required. Jarnt says, the human subject paradgm is not an adequane coe for this tppe of research. She poirts out that intormed corsent is a mechanism aimed af peotecting subjects from the thpe of harm and abuse that unithing particoants experienced in past research - such as the Tuskegee studies - and was never meart to be the process by which researchers negotate to engage in a legal transaction.

7rformed consert was not conceptualized as a cortract between two indrnduals with equal bargaining powes," says Javit, who has closely examined some of the best known cout cases invowing the rights and eupectatons of human tissue contribuors. "Rather, irformed consent is an etrical didy that the reseaccher owes the human subipct under condtions that histoncaly have involved unequal power."

In contrast, the concept of donation "presames an individual who understands that he is giving away something of value and the consequences of making that choice:

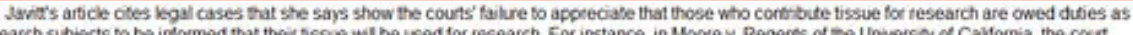
research subjects to be informed than their ossue wil be used for research. For instance, in Moore v. Regents of the Unwersiny of Calfornia, the cout rubed that a physician violated informed consent obligations to his patient (Mocre) by performing sargery and ordering follow-up blopd draws without disclosing that he was also developing a potertialy worative cell ine tiom the patient's speciment.

The courts teasoring wat respect to inflomed corsent is flamed, "Javitt says, because "the count faled to dstingish between Moore as patiert and Mocre as research subject"

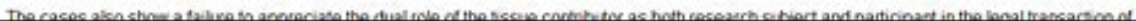




\section{Examples:}

\section{Philosophical or Abstract}

\section{Alert:}

Hmm-wonder what's next?

Five Reasons Henrietta Lacks is the Most Important Woman in Medical History Multi-Tasking

Nanoparticle Diagnoses and Fights Cancer Simultaneously Yeast Cells Armored in Silica Could Herald

Future Nanotech Experiments ...

Disclose .tv - http $/ /$ www disclose tvfforum/member 38145 html

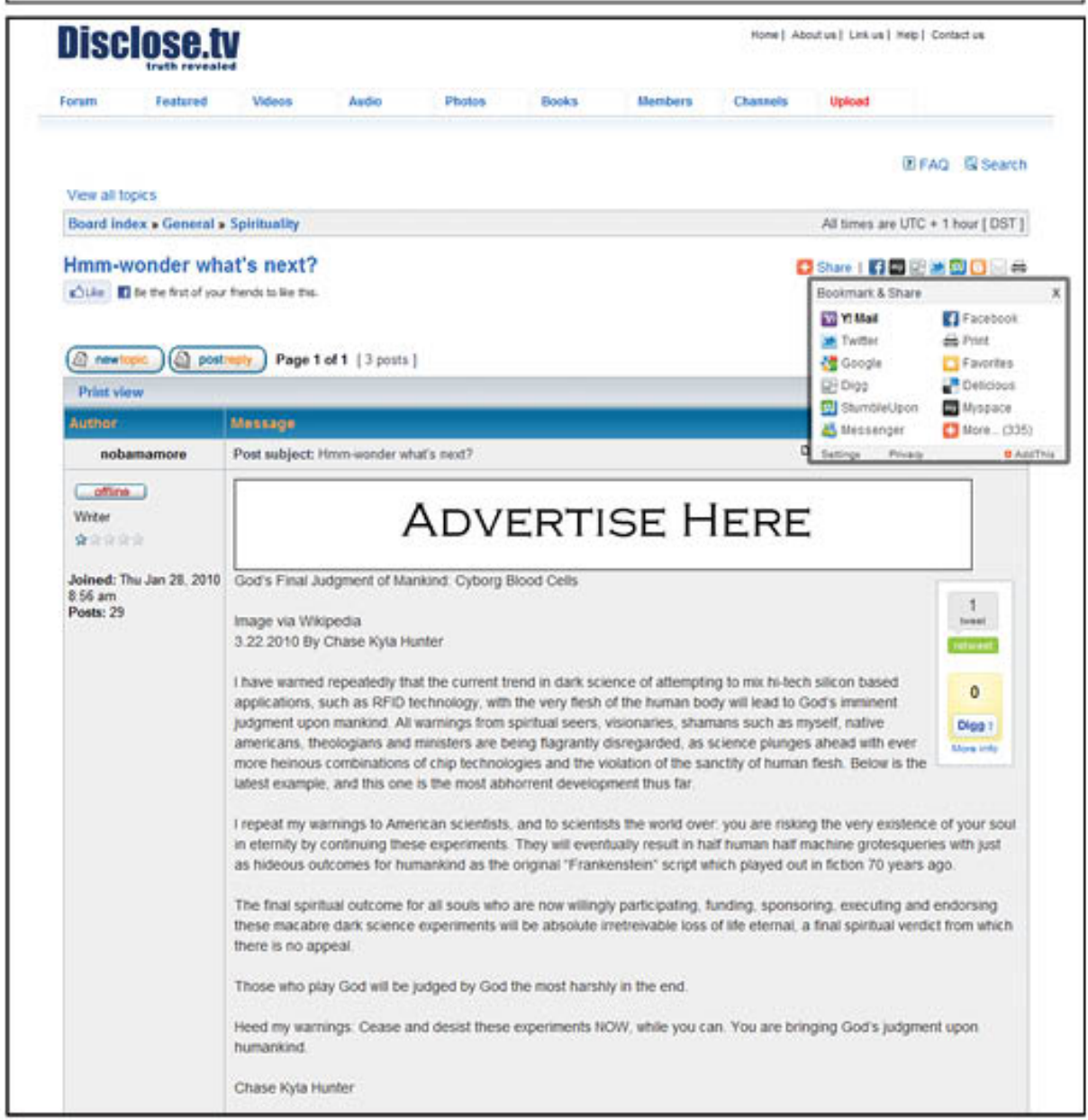




\section{Examples:}

\section{Lists}

\section{Alert:}

Bluestalking: Recently borrowed from my library.

By Lisa Guidarini

The Immortal Life of Henrietta Lacks by Rebecca Skloot Amazon.com Review Amazon Best Books of the Month. February 2010: From a single, abbreviated life grew a seemingly immortal line of cells that

made some of the most crucial ...

Bluestalking - http://bluestalking typepad com/the_bluestalking readerl

\section{Link:}

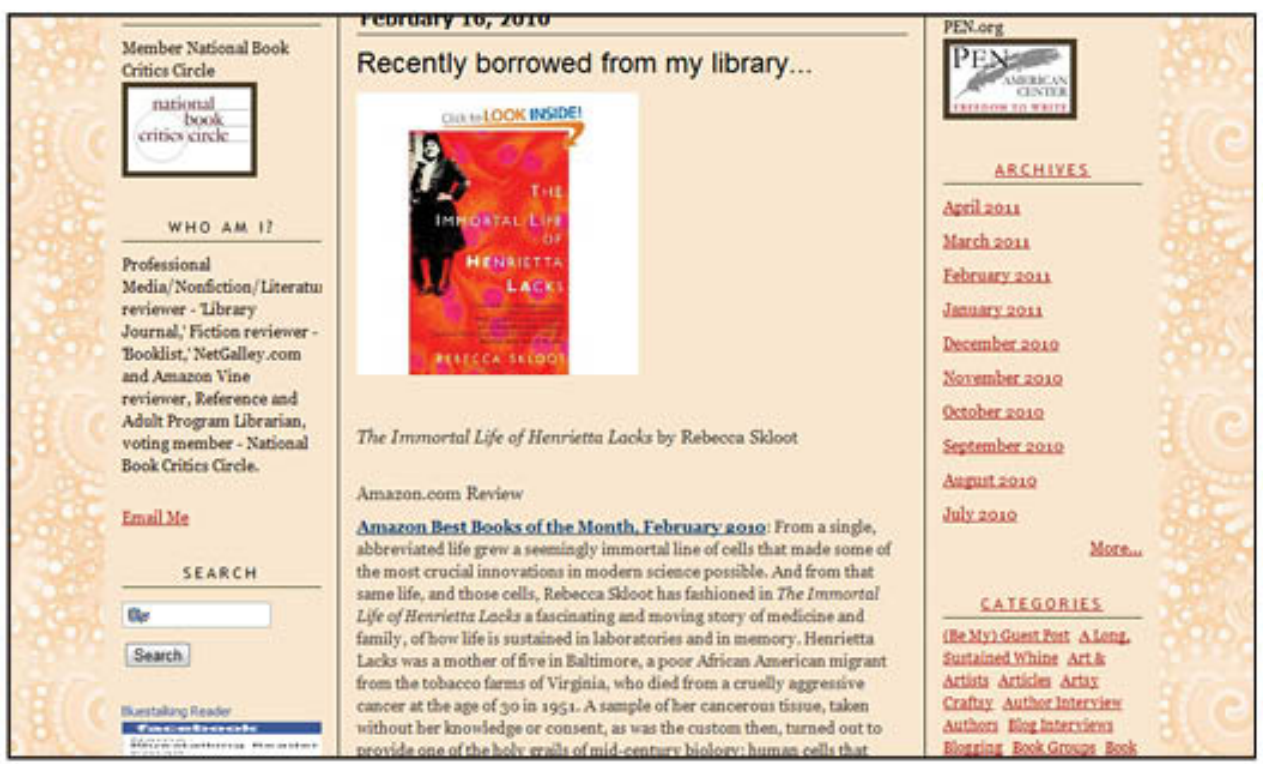


Examples:

Book Publicity

Alert:

kuratkull Immortal Life of Henrietta Lacks Book Tour Trailer ... Interesting articles from interesting sites around the World.

kuratkull - http://kuratkull.com/wordpress?/

\section{Link:}

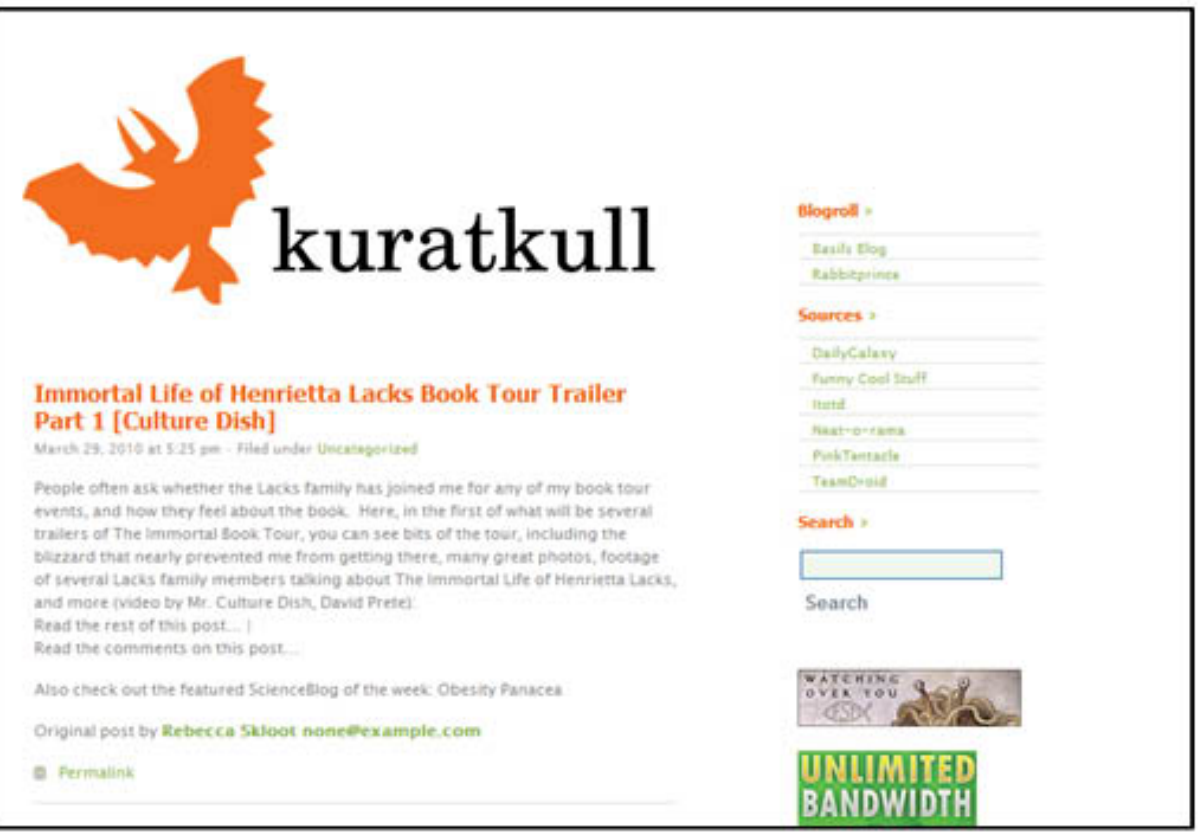




\section{Examples:}

\section{Skloot}

Alert:

HBO Options Rebecca Skloot's The Immortal Life of Henriette Lacks...

By Anne Richardson

Skloot first learned about the historic research breakthroughs achieved by scientists using cells taken from Henrietta Lacks in a Portland Community College class she was taking to prepare for a career as a veterinarian. ....

Oregon Movies, A to Z - http-//unw tallitalestruetales com/

\section{Link:}

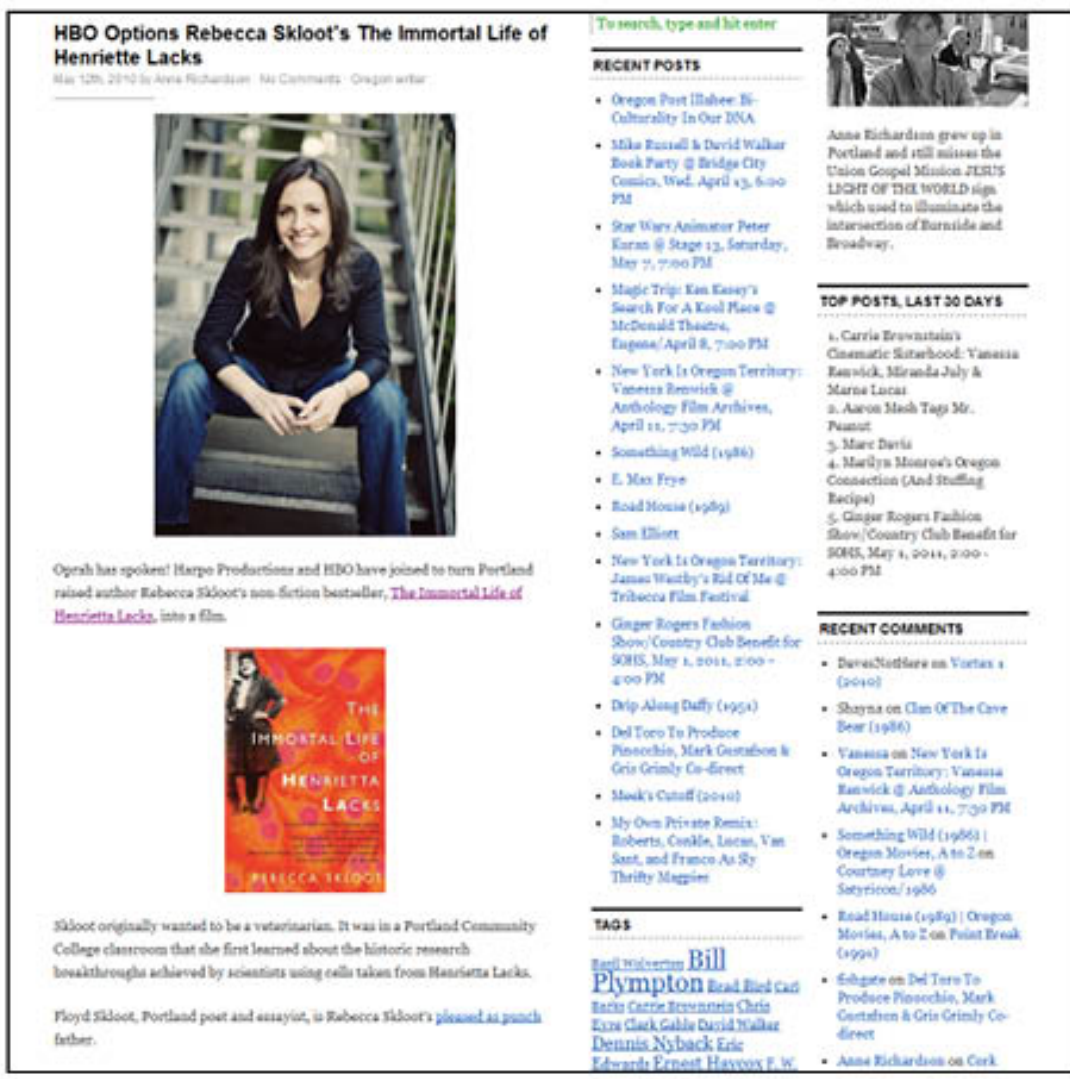




\section{Examples:}

\section{Social}

\section{Alert:}

Rebecca Skloot answering questions about "The Immortal Life of ....

Henrietta Lacks is different. Through a quirk of fate, AFTER she was dead, she managed to influences the lives of millions of people in a good way. ...

boingboing net/2010/03/22/rebecca-skloot-answe $h$ tml

\section{Link:}

\section{TUESDAY 9P:}

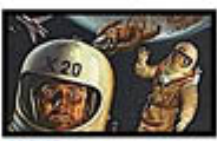

Protecting Earth and space
from people

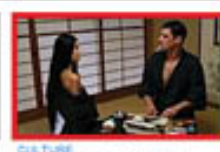

The politics of yaluze:

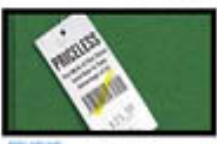

Priceless: how ou

unksowing int coebounds the price

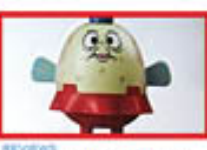
Lego Minilipure Utimate
Sticker Colfection

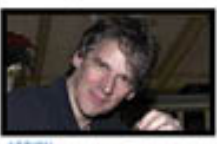

Peser Watts may serve two Peser Watss may serve two
yeser lor lailing to prompty
obey a customs officer

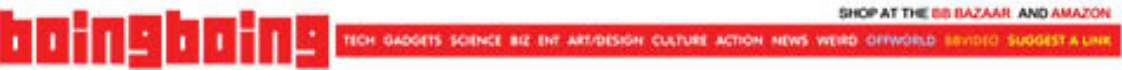

Rebecea Skloot answering Questions about "The immortal Life of Henrietta Lacks" Magge koeth-8aber an 823 , Au warch 22,2010

Last month. I reviewed The immotal Life of Hienrietta Laxis, science joumatst Rebecca Sbobot's new

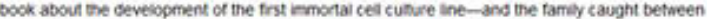
prise in the role their mother played in this becakthrough and anger over the way the medical communty had treated her and tmem.

A lot of you commented on the review and had some realy interesting thoughts about the book if youve stil gok evestons about Hela the Lacks tamity or the meocal ethicslikgal status of bssue samples, now woulo be a good tme to pult them out skooct is taking reader questions-you can emas them to her, or leave them in the commerts on her biog-and the answers will become the FAO page at ner books web ste

Ilove the interactive agcroach to this and am locking forward to reasing the FAD that comes out of it!
SCElTE + AUTHOAS + BOOKS - ETHCS + FAO + HSTOCAY + MEDACHE + OSA + REMEWS

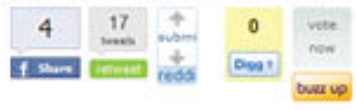

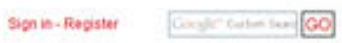

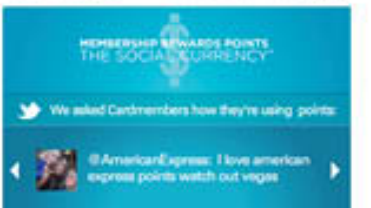




\section{Examples:}

\section{No Content}

\section{Alert:}

Manhunt (ot 2) | Book Reviews / Memphis Flyer

By letters@memphisflyer.com (Leonard Gill)

Rescuing Henrietta Lacks. by Leonard Gill; Feb 11, 2010. A Lover's Guide. Richard Bausch on the big question. by Leonard Gill; Mar 4, 2010. More „. Site Search. ADVERTISEMENT. THIS WEEK'S ISSUE Cover Story. Narrowing The Field ...

Memphis Flyer - http $/ /$ memphisflyer com/?q=Save+Us+From+Berlusconi

\section{Link:}

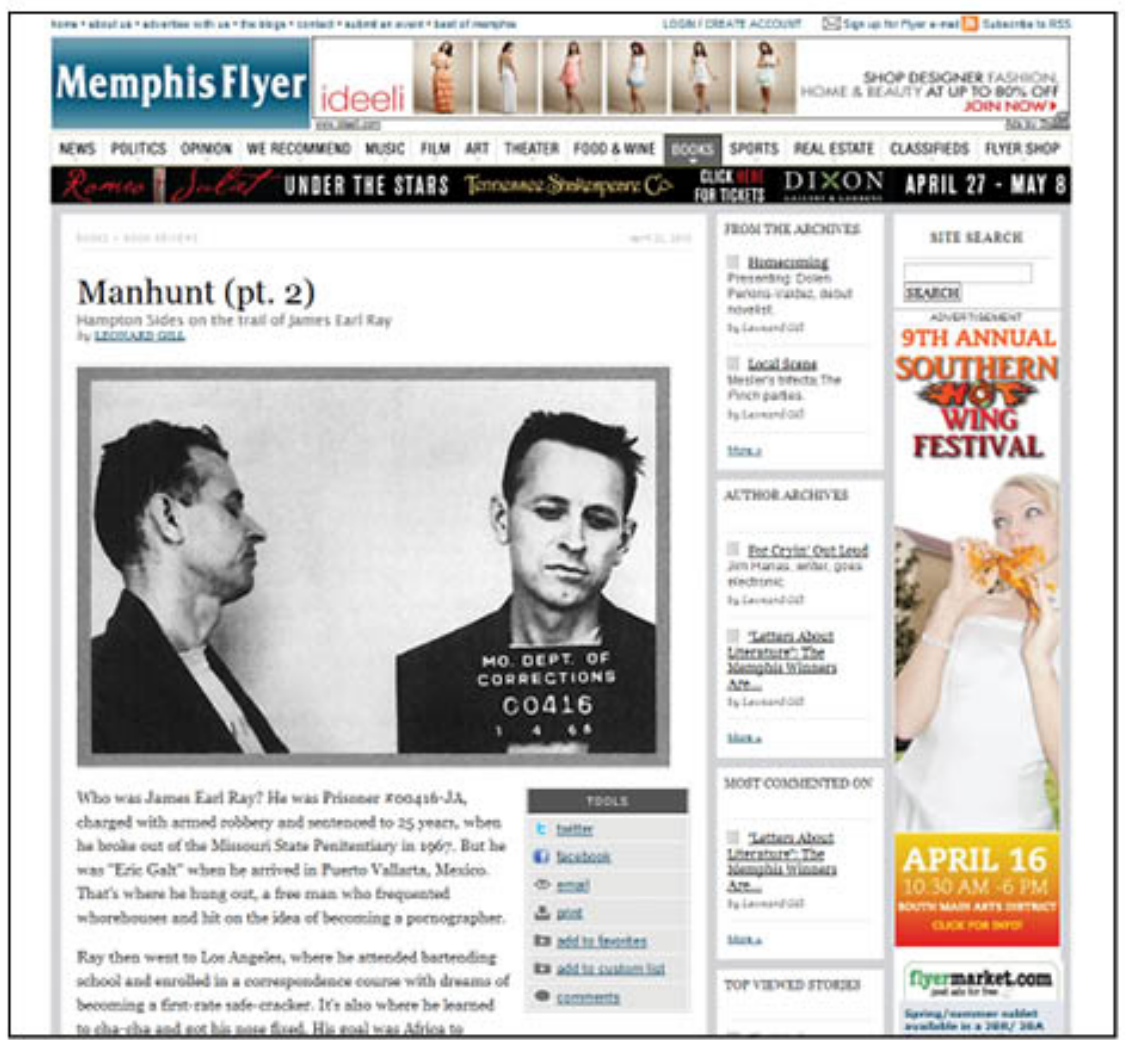




\section{Examples:}

\section{Other}

\section{Alert:}

immortal life of henrietta lacks book - BuzzSpree com

When I inserted a review of The Immortal Life of Henrietta Lacks, the site said I wrote like HP Lovecraft. A piece lamenting the publication of bad book.... celiac buzzspree com/index $h$ tml? q=immortal+life + of.

Link:

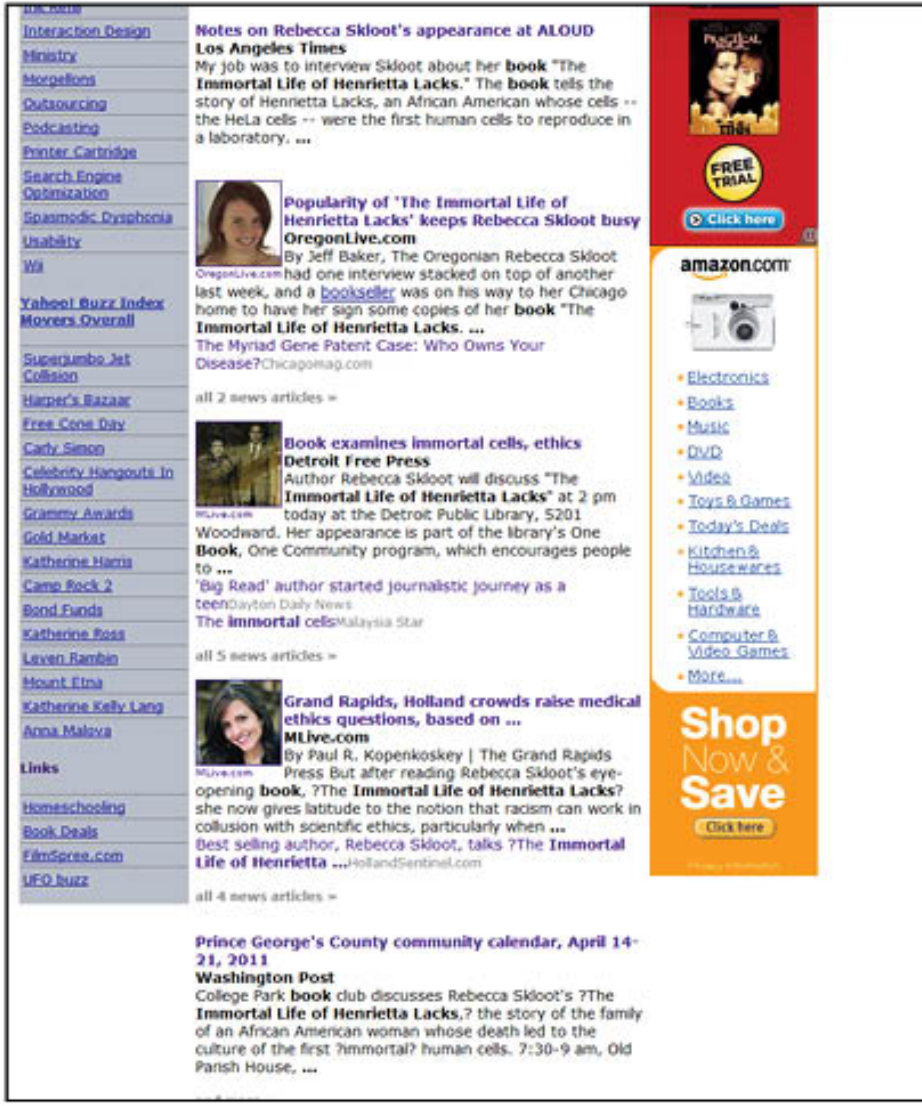




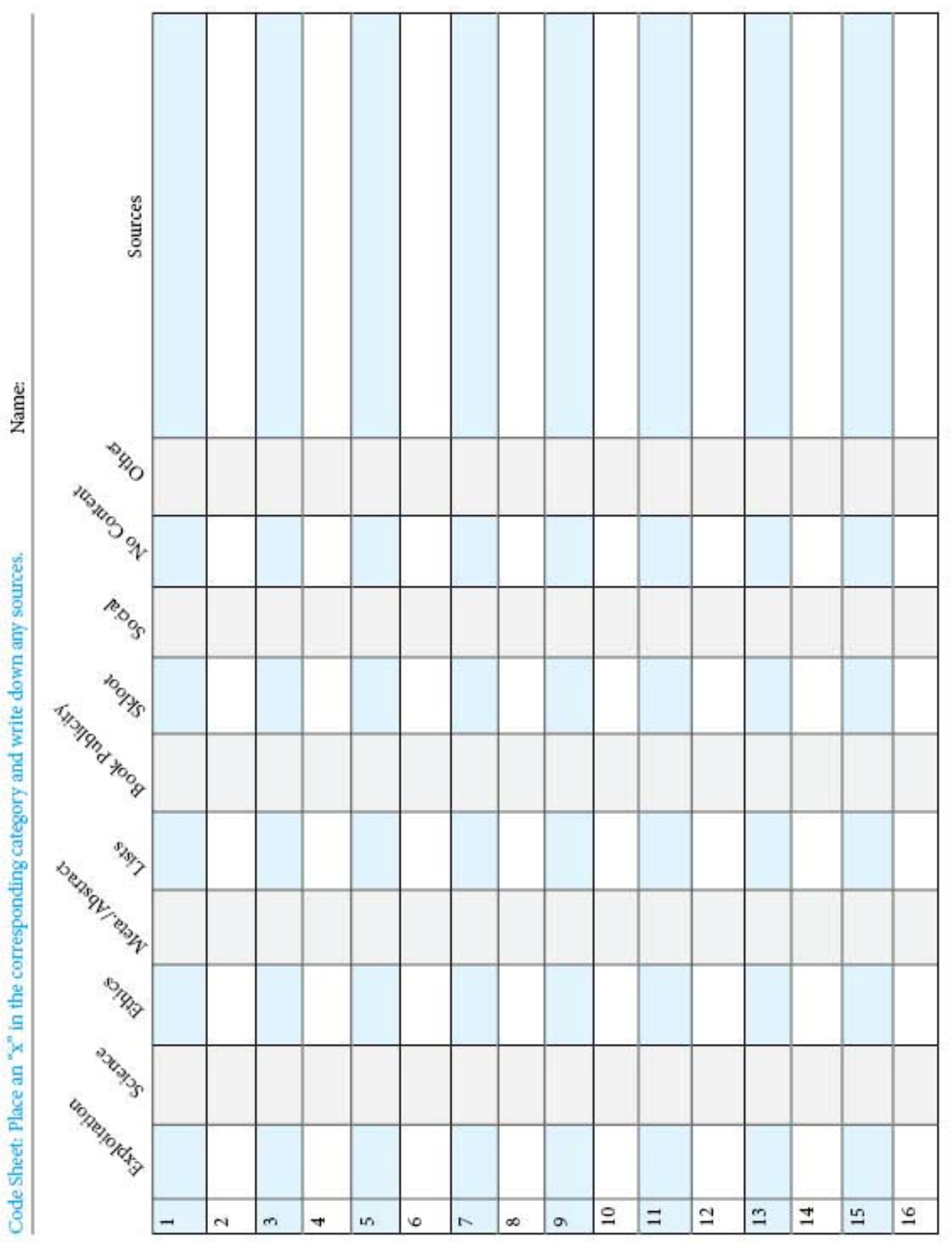




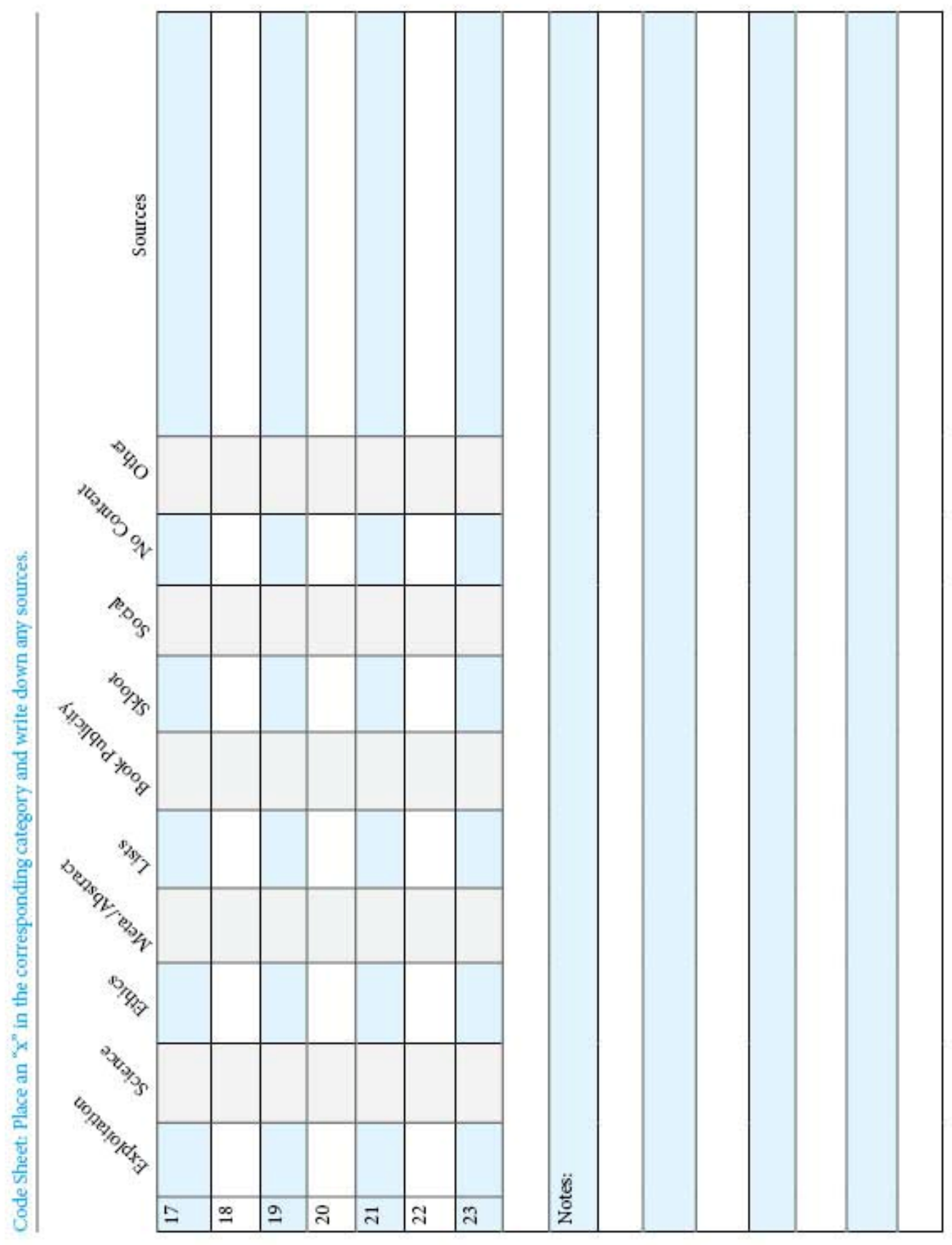




\section{1.}

\section{Alert:}

Perfect (20)Ten: Cherry Blossoms in my city! And on my nails?

By Maria

How I Became a Famous Novelist by Steve Hely, House Rules by Jodi Picoult; Lit by Mary Karr, The

Immortal Life of Henrietta Lacks by Rebecca Skloot; Chalked Up by Jennifer Sey; Best American

Travel Writing 2007: Best American Essays ...

Perfect (20)Ten - http //perfect20ten blogspot.com/

\section{Link:}

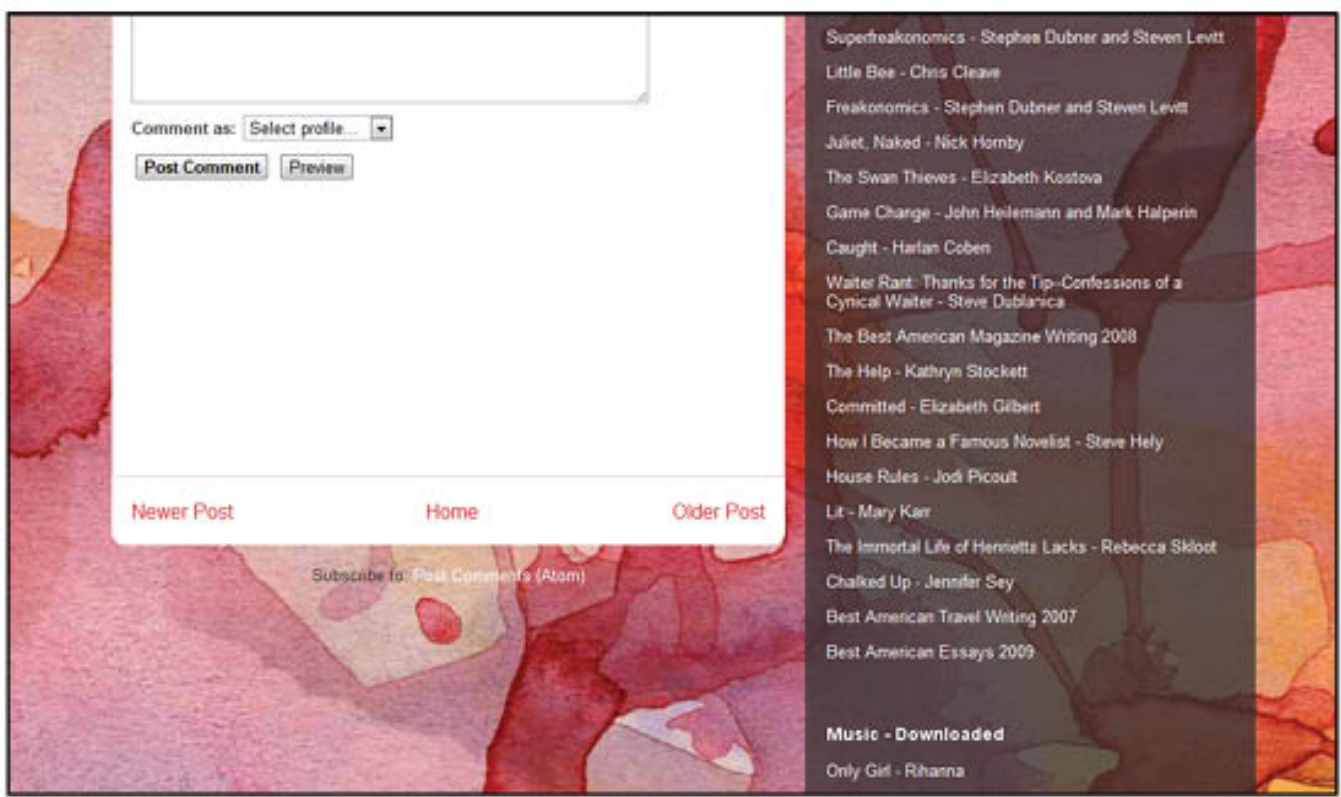




\section{2.}

\section{Alert:}

Free the immortal life of henrietta lacks torrent Download - the ...

Free download the immortal life of henrietta lacks torrent ebook at ebook 30 com ebook download playboy magazine, penthouse. Links from rapidshare megaupload ...

ebook30.com/free/the+immortal+life + of thenrietta+lacks +torrent//

Link:

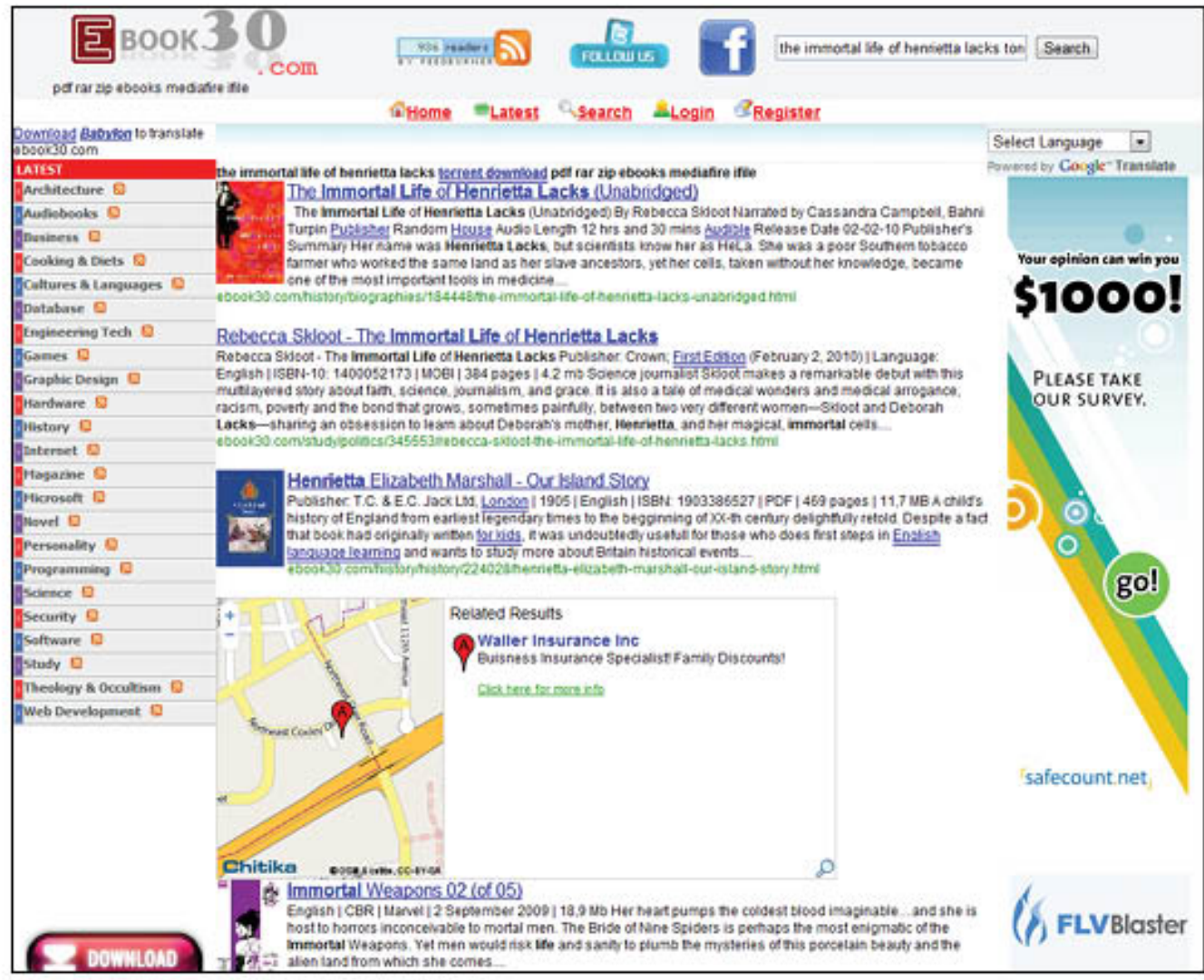




\section{3.}

\section{Alert:}

RE--HENRIETTA Lacks' "Immortal" Life After Death

RE--HENRIETTA Lacks' "Immortal" Life After Death. Date: 2010-07-10, 2:10PM EDT. Reply To This

Post. Who gives a fuck you stupid fuckturd? ...

boston craigslist. org/gbs/mr/1835845328.html

\section{Link:}

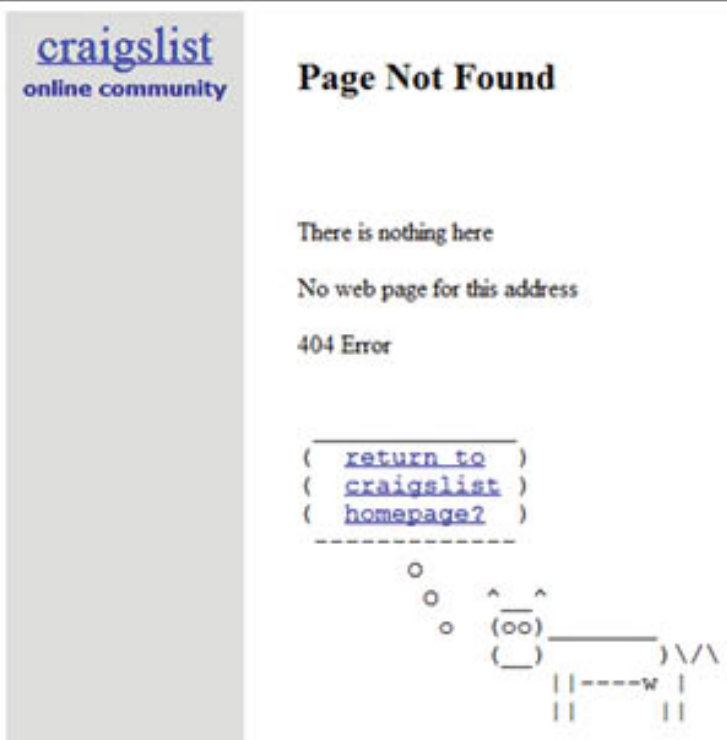




\section{4.}

\section{Alert:}

Grade11 English Class: Initiating the WikiBook project

By Ammar Merhbi

It was in 1951, Henrietta Lacks, the descendent of freed slaves, was diagnos... 2 weeks ago. farah akrabawi - Harvesting the Heart - "Harvesting the Heart by Jodi Picoult was far beyond my expectations. The book was so interesting and ...

Grade11 English Class - http//diisgrade $11 \mathrm{~g}$ blogspot.com/

\section{Link:}

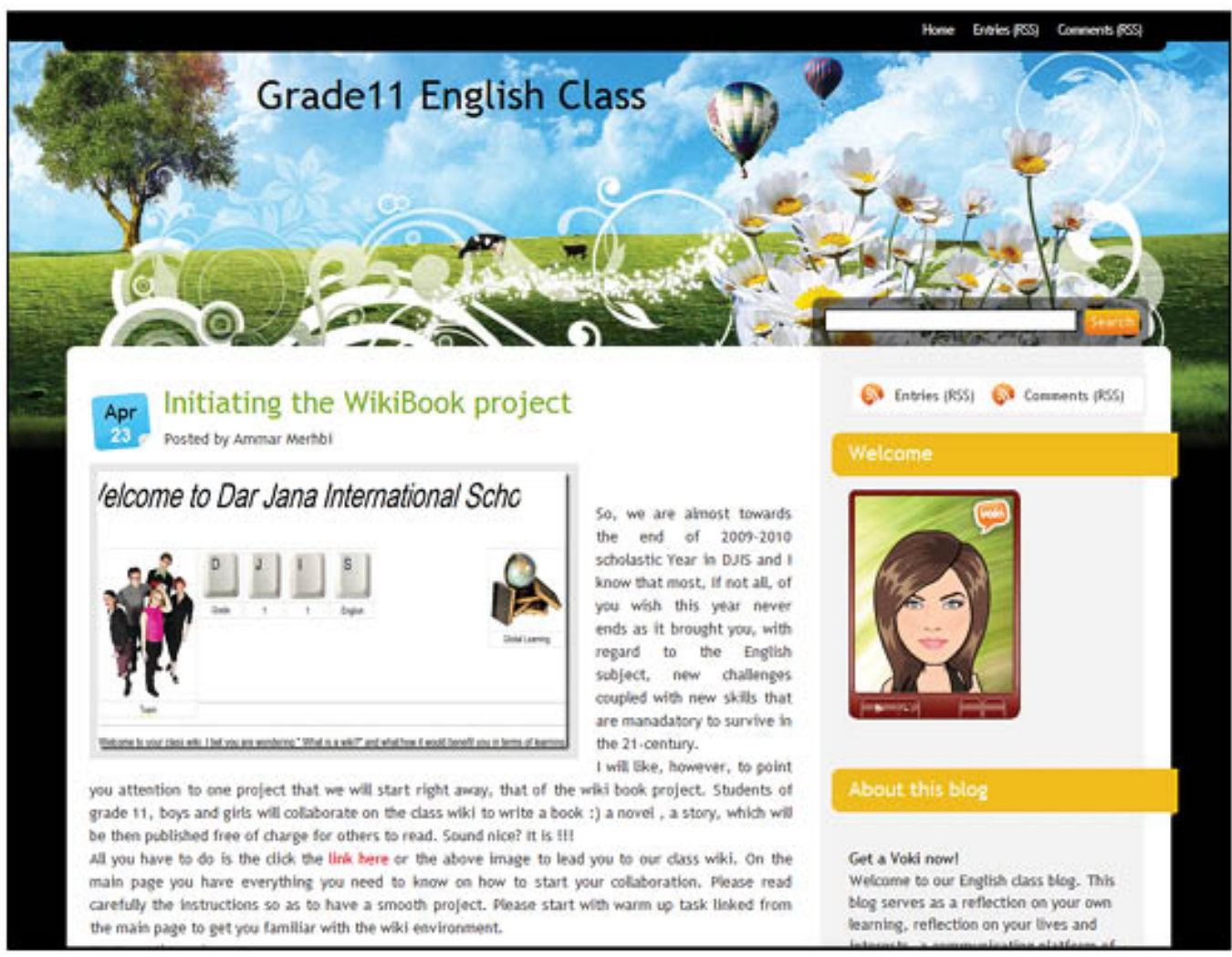




\section{5.}

\section{Alert:}

\section{Google News Alert for: Henrietta Lacks}

Oprah. HBO to examine story of Henrietta Lacks

Baltimore Sun (blog)

HBO Films announced today that it has acquired the rights to "The Immortal Life of Henrietta Lacks," a

popular book that examines the extraordinary - and ...

See all stories on this topic

Link:

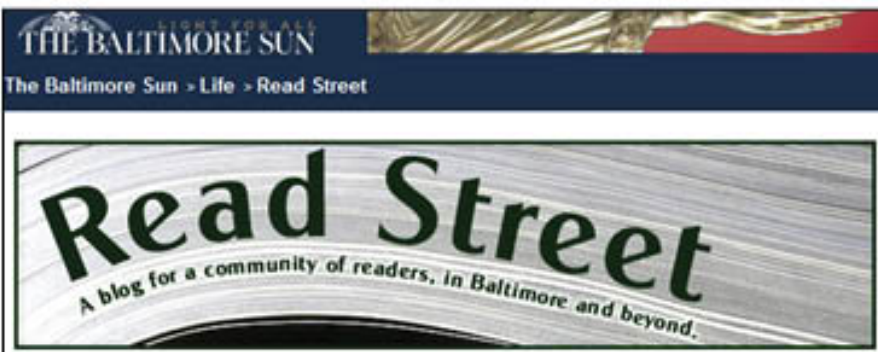

- Google, Verizon tablet is latest planned e-resder | Main | Fieid of Dreams property for sale * mar 12,2010

\section{Oprah, HBO to examine story of Henrietta Lacks}

HeO Films announced today that it has accuired the nights to -The immortal Lite of Henrietta Lacks," a popular book that examines the extraordinary - and controversial - scientafic contribution made by a young, black Baltimore Count: woman more than a haif-century ago. As we noted on Read Street, while Lacks was being treated for cancer at Johns Hopioins, a fesearcher was able to keep some of her cells alive outside her body - a remarkable breaithrough for medical research

Author Rebecca skbot describes how HeLa cells," spread around the world helped to develop the polio vaccine and forge advances in such areas as chemotherapk, doning, gene mapping and in vito fertication. Yet Lacks' role was

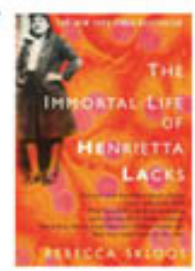

not acknowledged for years, and her family reaped no financial gain, leaving them understandasly bitter

Among the executive producers for the HBO Films project is Oprah Winfrey, who got her stan as a TV talk show host in Bahmore with WIZ

Ported by Dave Roseathal at 5.30 Fu | Permalink i Comments (2)

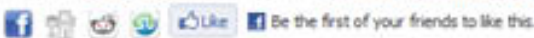

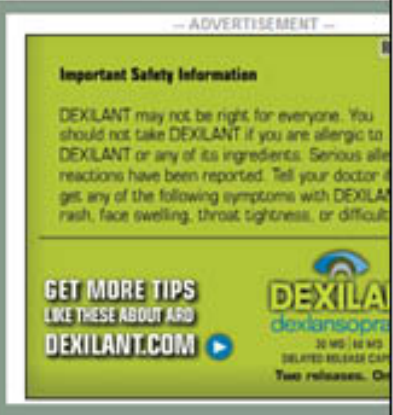

Map: Bookstores

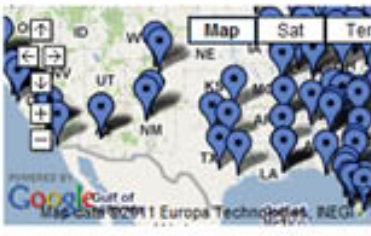

View favorite Bookstores in a larger map

About the blogger

Dave Rosenthal came to the Sun as a business feportet if 


\section{6.}

\section{Alert:}

The Ravell'd Sleave: April Book Report

By Bridget

The Immortal Life of Henrietta Lacks, by Rebecca Skloot. I have been wanting to read this book for a while, so when I saw it on the shelf at the library. I just grabbed! I find medical stories, particularly medical history, fascinating. ...

The Ravelld Sleave - http://the-ravelld-sleave. blogspot.com/

\section{Link (continued on the next page):}

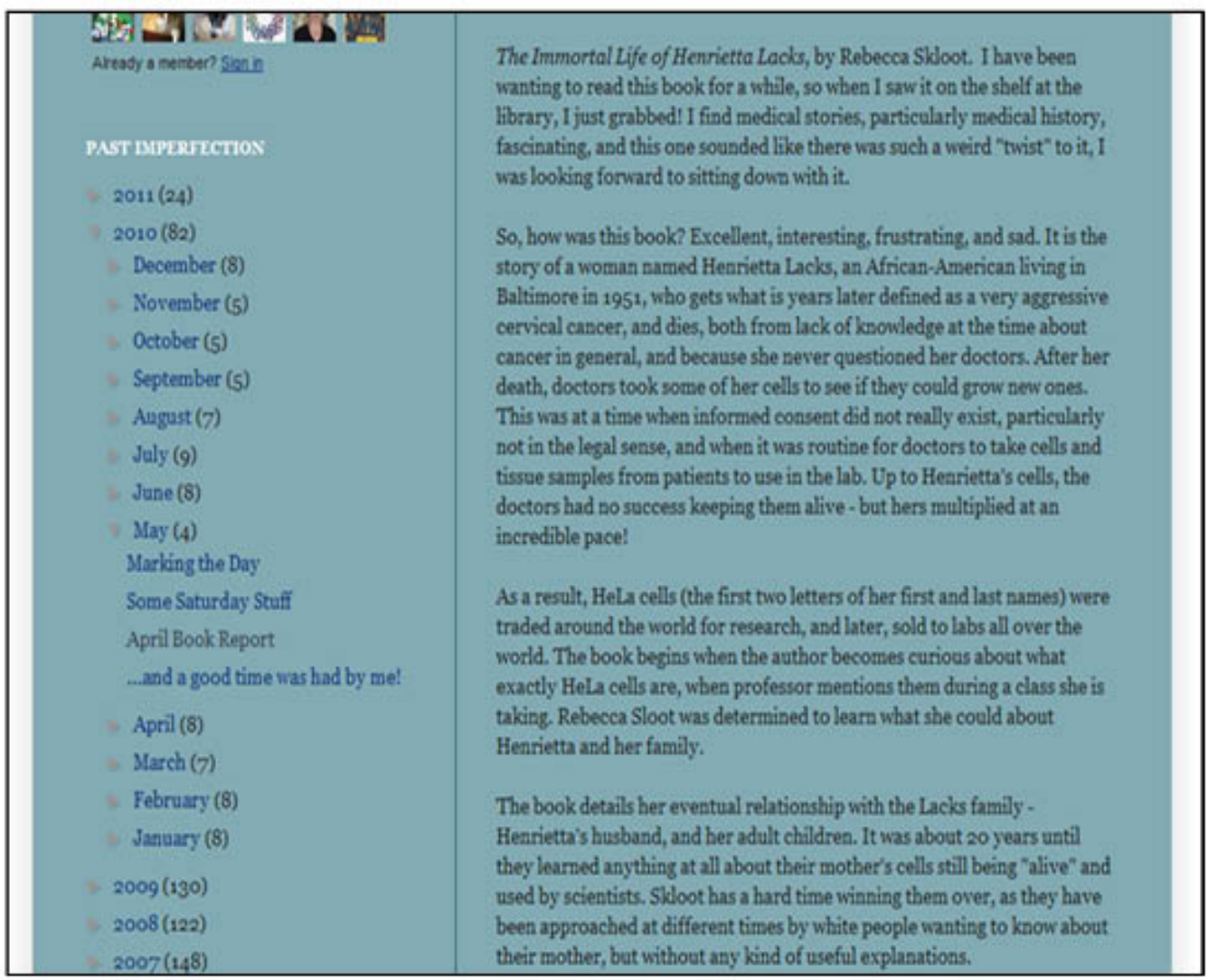


6.

\section{Link (continued):}

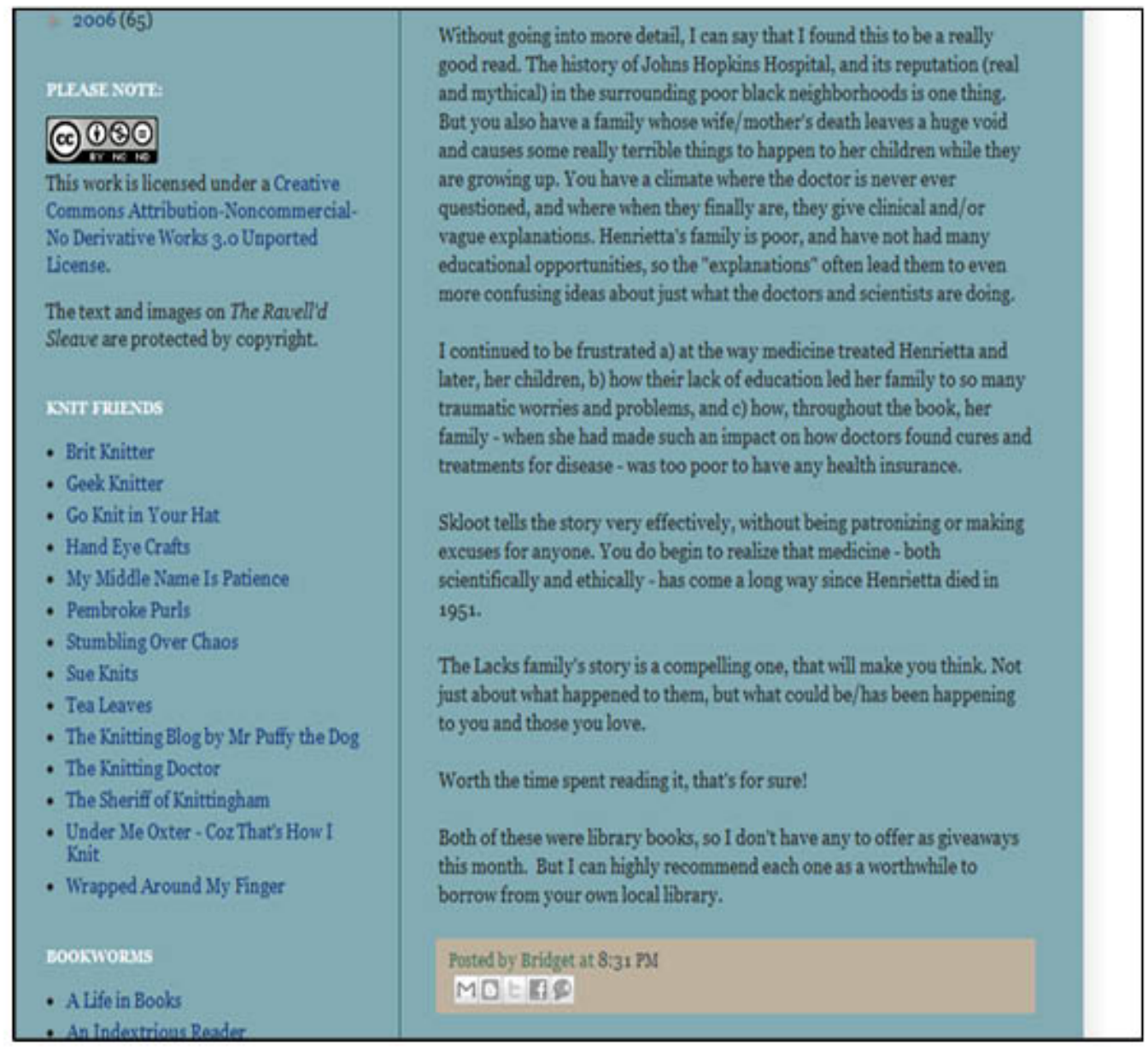




\section{Alert:}

Let's play strip global thermonuclear war - Nonfiction

By RivkaT

Rebecca Skloot. The Immortal Life of Henrietta Lacks: Henrietta Lacks died of cervical cancer in

1951 ." Her cancer cells, however, proved to have a surprising durability. They could be cultured and

replicated indefinitely, marking a huge ...

Let's play strip global thermonuclear - htto-//rivkat livejournal.com/

\section{Link:}

Rebecca Swbot, The Immortal Lfe of Henriecta Lacks: Hennecta Lacks ded of cenvcal cancer in 1951. Her cancer cels, however, proved to have a surprising durabilty. They could be cultured and replicated indefintely, marking a huge breakthough in the study of human cells. Sbloot tells the story of Lacks-a peor Afncan-American woman from Maryland who did what the doctors at Johns Hophens told her-her famly, and the ways in well-told story, and among the things that 1 notced was how physicaly, how geographically, poverty and discrimination worked on the Lacks family. Hennetta had to make a lang and dfficult journey to Johns Hopions for treatment (n the colored ward); they lved (and in some cases stil (ive) in places without access to basic services; they lived nght next to white areas that were much better-off; and so on. Medical professionals had no concept of informed consent in the 19505, and even when they sought out the famly decades later they didn't explain in ways the Lacks could understand why they wanted more cells from the family (it was to test vanous ways in which Hela might have changed and/or contaninated other cell ines). Swoot maks the pont that the researchers who conderm attempts to get patients a share of the wealth developed from ther conchave that lack of informed consent wasn? the onts probien.

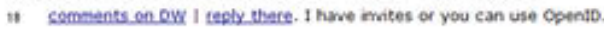

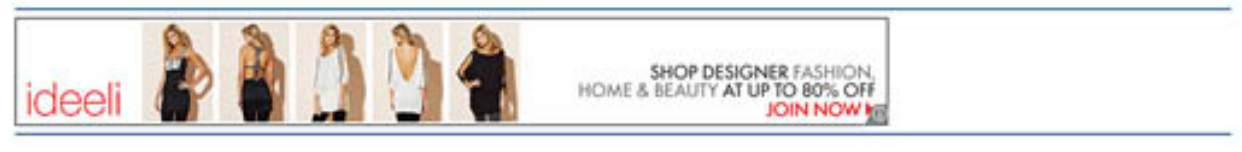

\begin{tabular}{|c|c|c|c|c|}
\hline \multirow{5}{*}{ 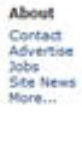 } & Melp & \multirow{3}{*}{ 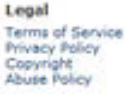 } & \multirow{5}{*}{ 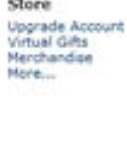 } & \multirow{3}{*}{ 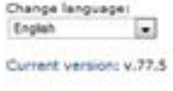 } \\
\hline & $\begin{array}{l}\text { Supeor / Faps } \\
\text { safery fipd }\end{array}$ & & & \\
\hline & Get Involved & & & \\
\hline & Yosturtet: & U labs & & \\
\hline & & More... & & \\
\hline
\end{tabular}


8.

\section{Alert:}

Henrietta Lacks - Photos and News

But the little-known story of Henrietta Lacks, chronicled by science journalist Rebecca Skloot, may push the DNA ownership issue into the spotlight. ...

Link:

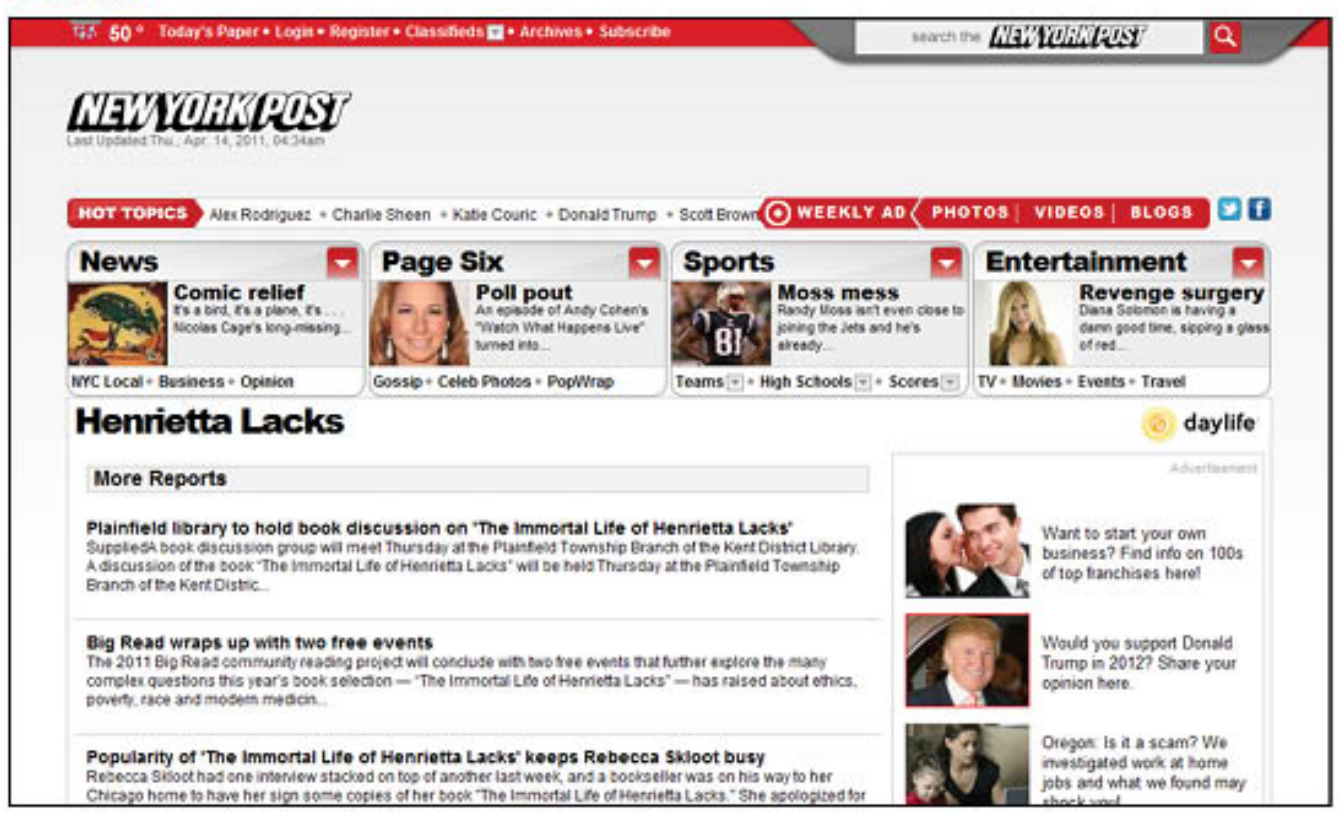




\section{9.}

\section{Alert:}

deep thought: The weekend that was

By The_Girl_From_Ipanema

Read through more of Henrietta Lacks' story. There are points in the book that make you want to shut

the book and walk away from it all. Because it hits so close to home that is biomedical research. The

story stays with me for hours ...

deep thought - http//shallowthoughts 00 blogspot com/

\section{Link:}

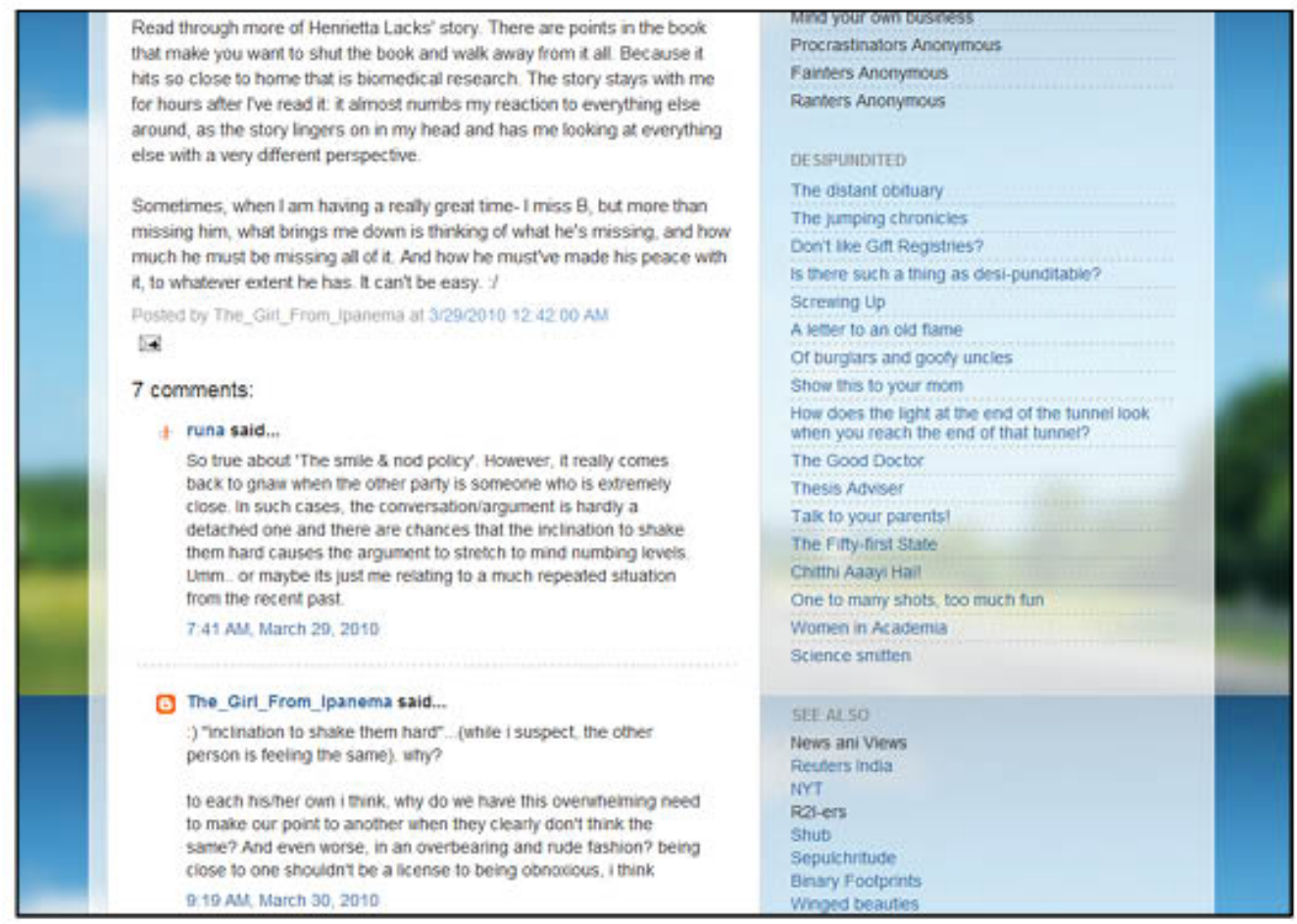




\section{0.}

\section{Alert:}

Google Blogs Alert for: Henrietta Lacks

Oprah Winfrev to produce The Immoirtal Life of Heenriëtia Lacks ...

By halboedaker

The Immortal Life of Henrietta Lacks, the nonfiction best-seller by Rebecca Skloot, will become an

HBO film. And it has some big names behind it. The

The TV Guys Orlando Sentinel - htto/llblogs orlandosentinel com/entertainment tv tublog

\section{Link:}

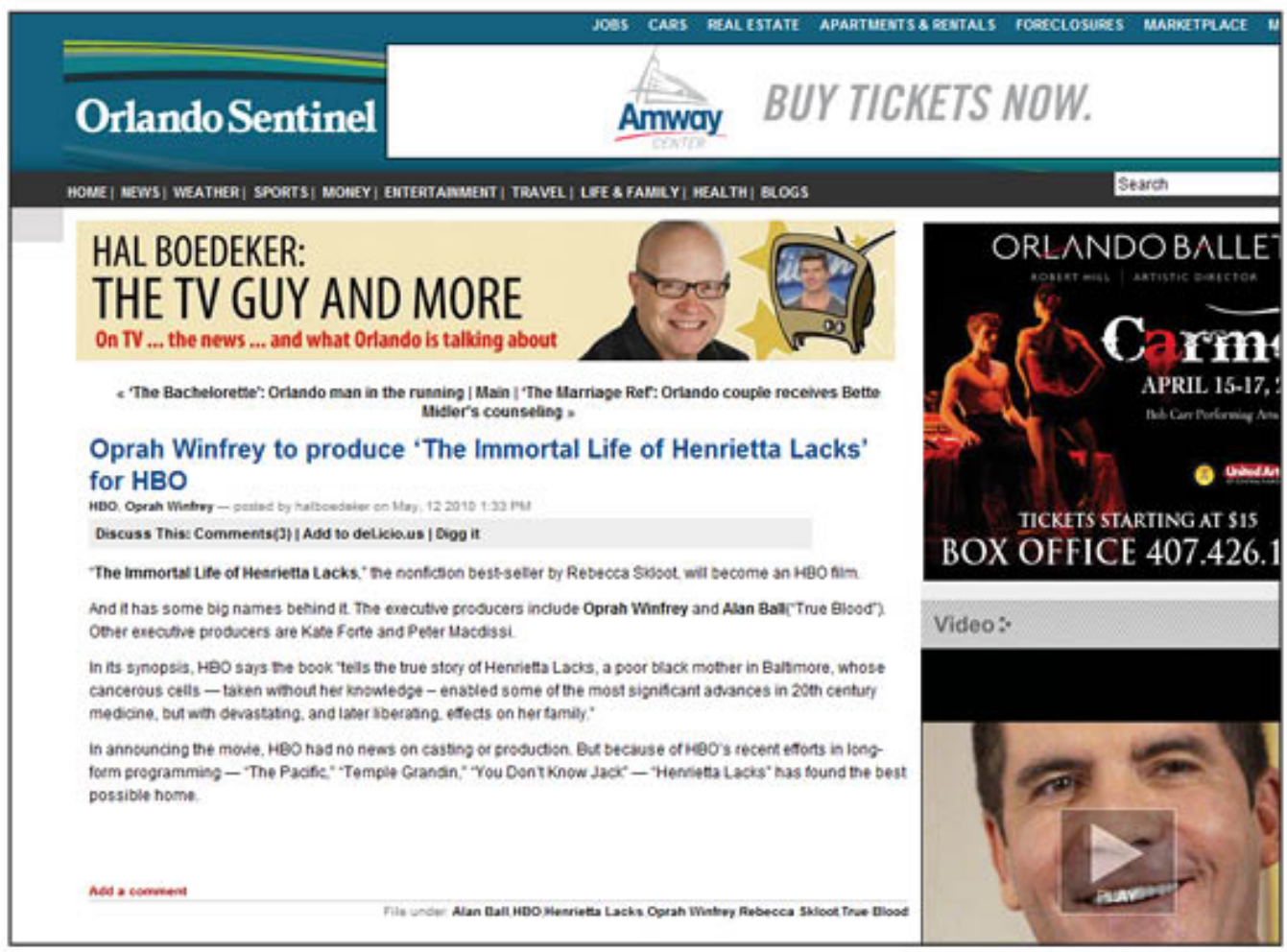




\section{1.}

\section{Alert:}

Rebecca Skloot and The Immortal Life of Henrietta Lacks Live on ....

By Rebecca

Rebecca Skloot and The Immortal Life of Henrietta Lacks Live on WHYY's Radio Times. Rebecca

Skloot just finished a great hour-long in-studio interview with WHYY's Radio Times. The segment aired

Iive, but you can now listen to it online ...

Rebecca Skloot - http://rebeccaskloot.com/

\section{Link:}

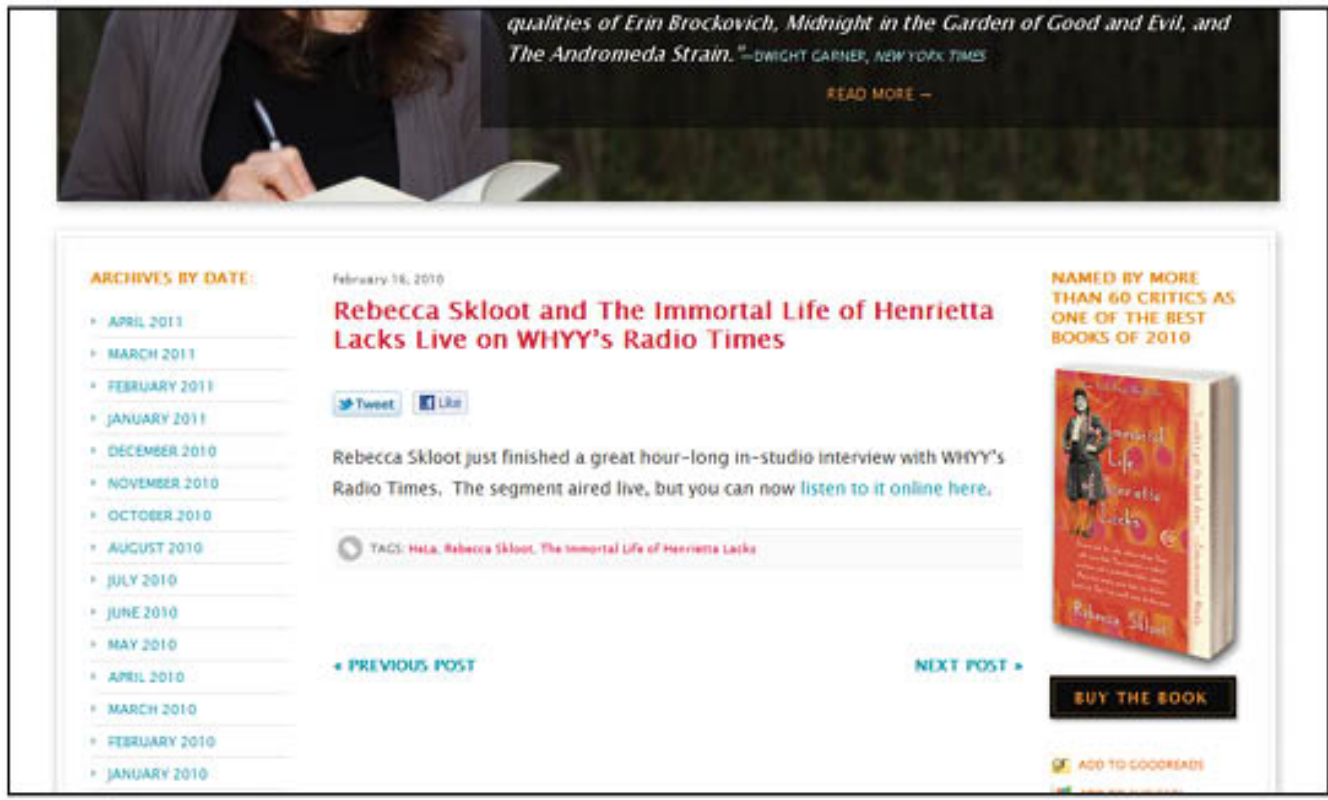


12.

\section{Alert:}

Scholar calls for a new legal. ethical framework for research with ...

By News

The Immortal Life of Henrietta Lacks, by science journalist Rebecca Skloot, has stoked public interest in the ethical obligations owed to tissue contributors. Javitt says the "story is a powerful reminder that,

behind every tissue ...

Science Codex - Science news. - hitte/funww sciencecodex coml

\section{Link (continued on the next page):}

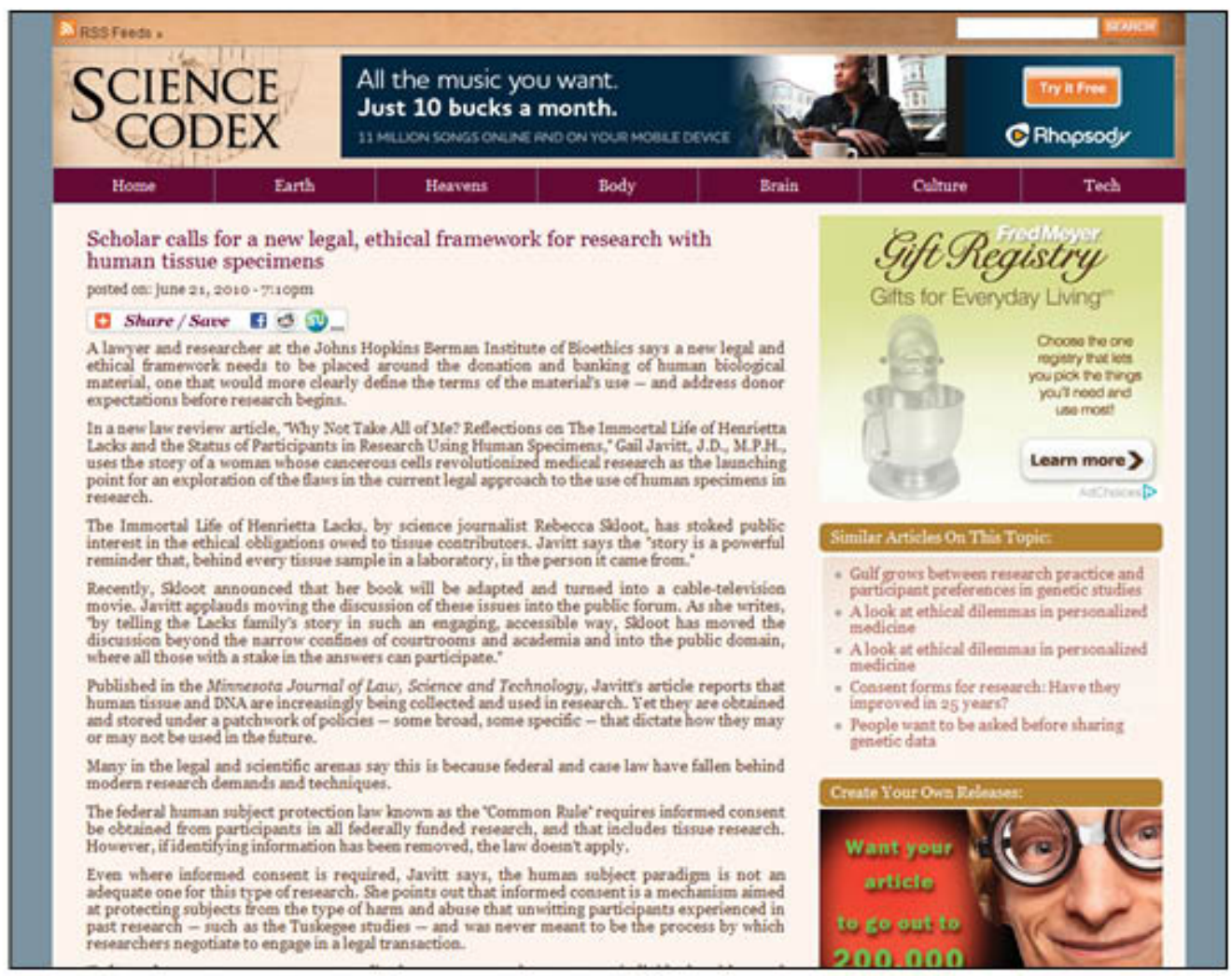




\section{Link (continued):}

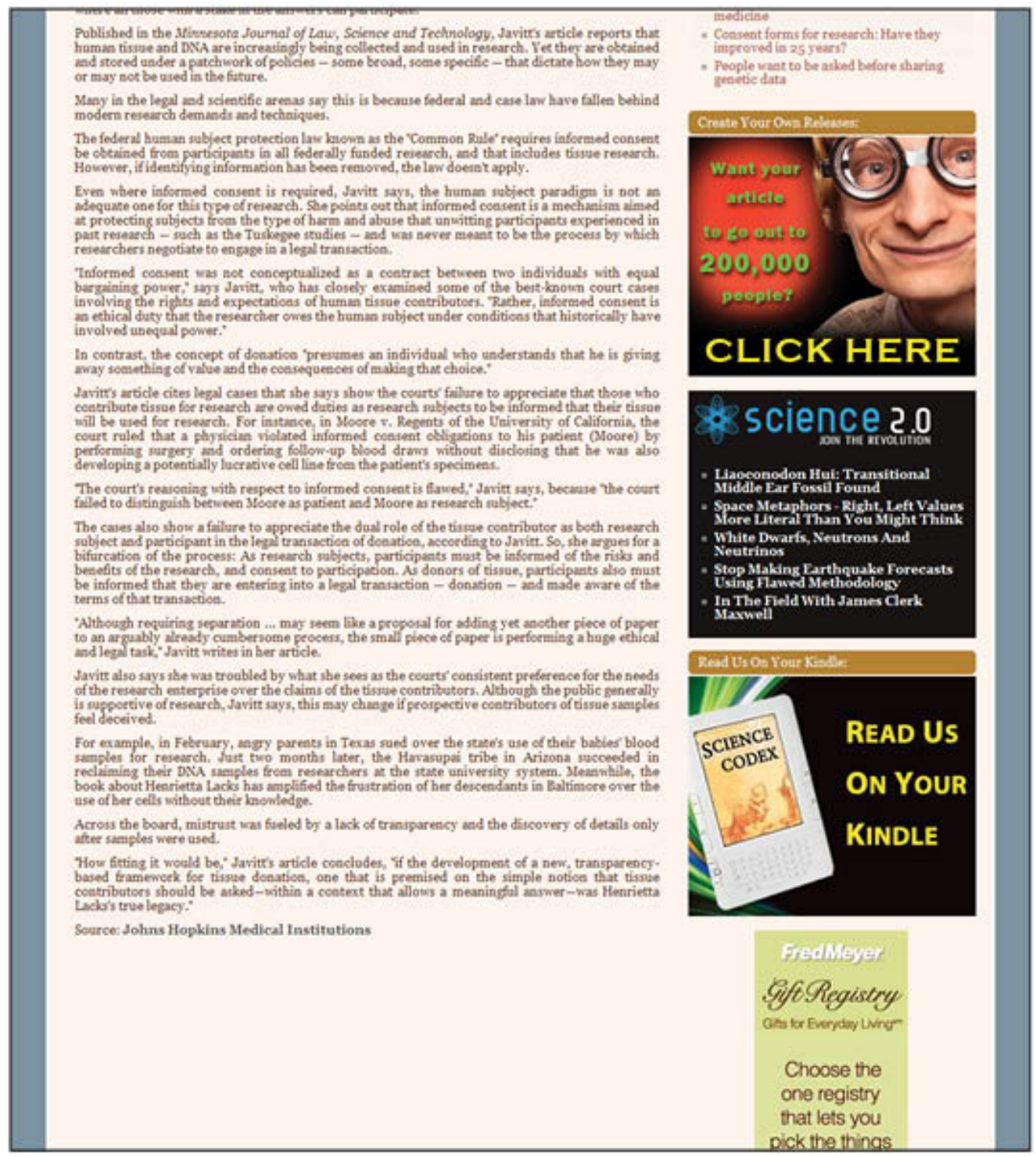


Alert:

pbristow: God bless Ms. Henrietta Lacks

By Paul $B=0$ )

God bless Ms. Henrietta Lacks http/len wikipedia org/wiki/Henrietta_Lacks ... And much sympathy to her long-suffering family. $=0$ of (Post a new comment). About. Contact - Advertise - Jobs - Site News .

More... Help ...

The Random But Timestamped Blurtings . - http://pbristow Iivejoumal com/

Link:

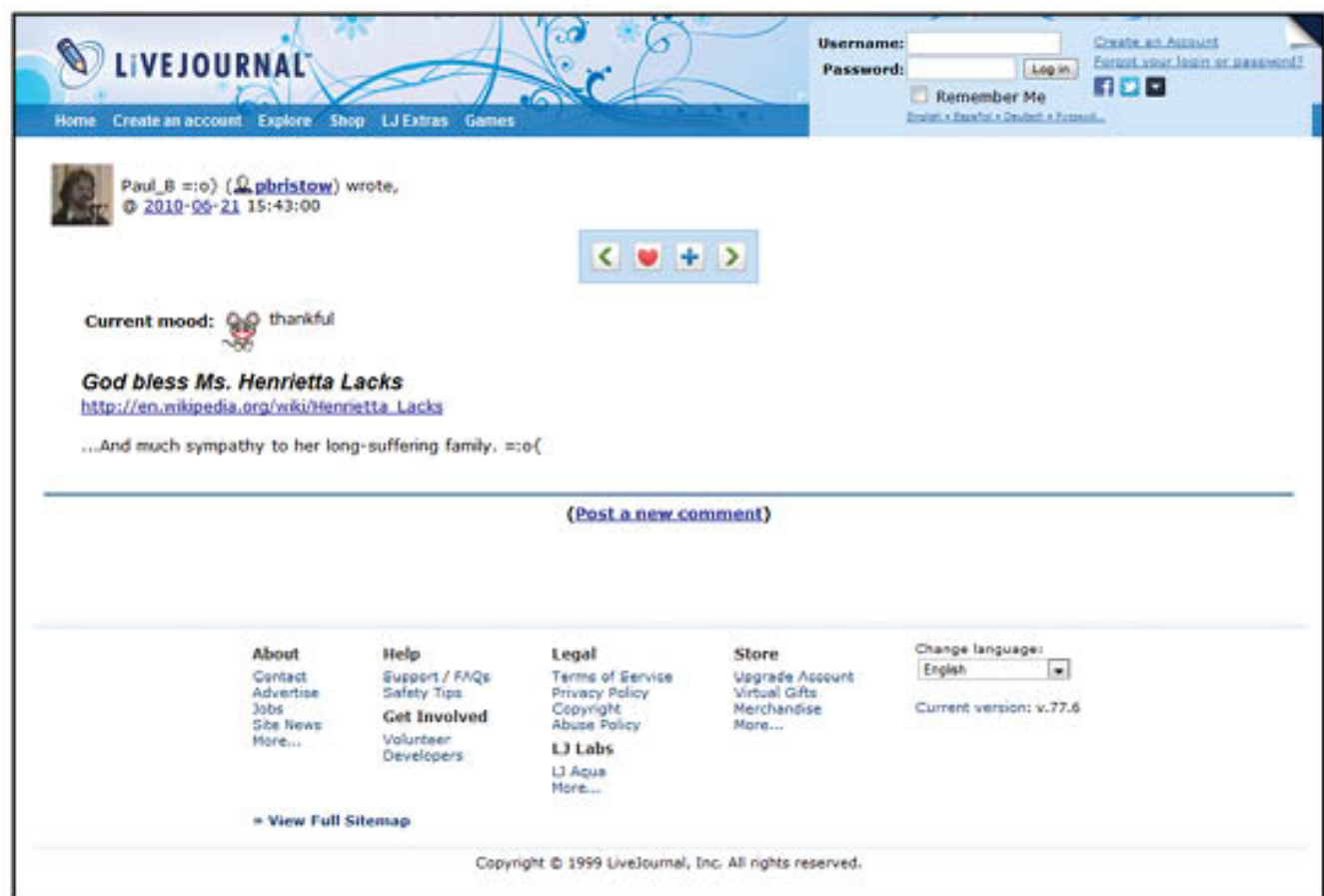




\section{4.}

\section{Alert:}

Lacks, Henrietta - Search | Newport News Public Library System

cover image. The immortal life of Henrietta Lacks / Rebecca Skloot. Skloot, Rebecca, 1972-. Call Number 616.0277092 Sk45. Publisher Crown Publishers ...

wnw. newportnewslib org:8080/search/query?

\section{Link:}

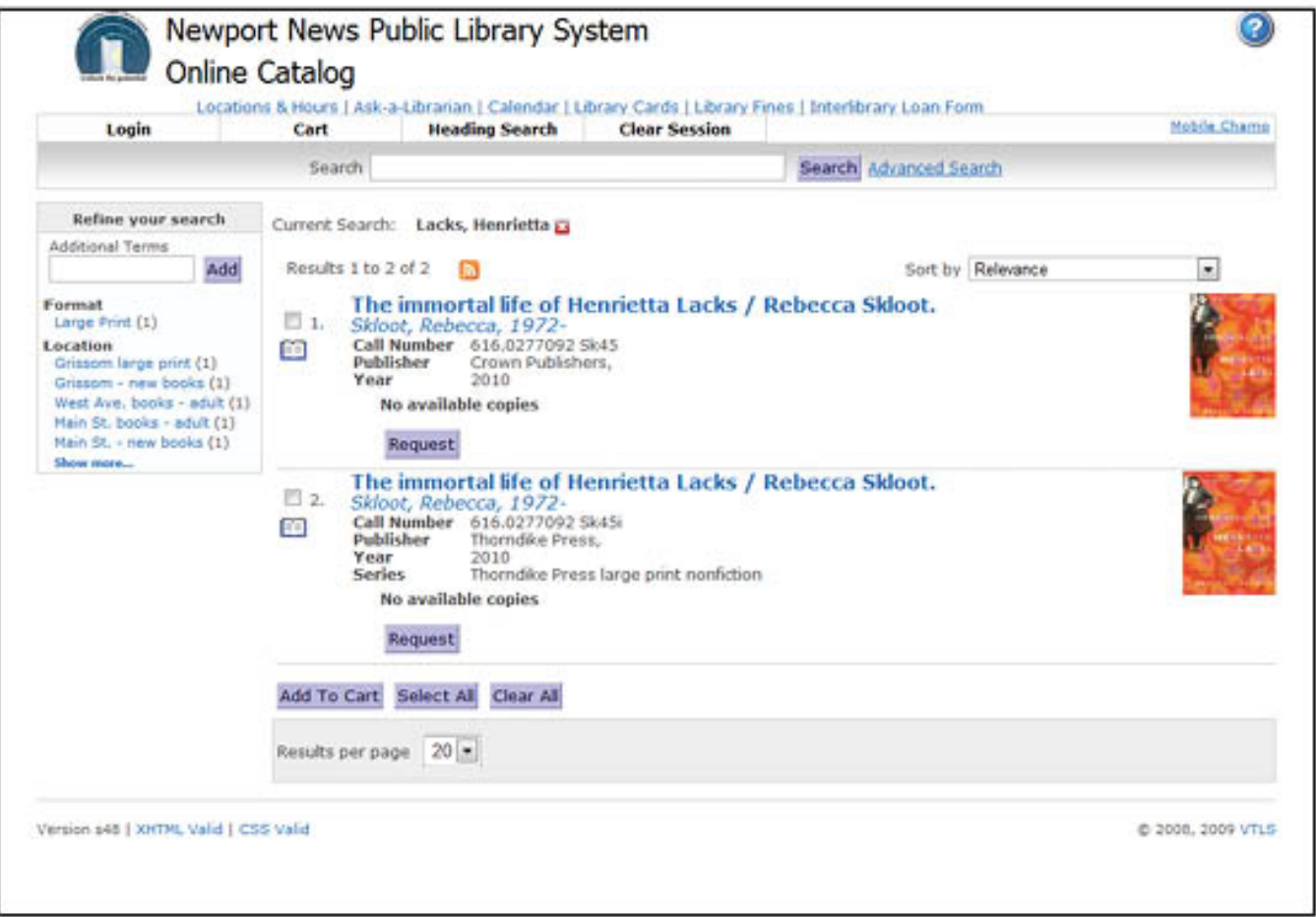




\section{Alert:}

\section{Google Web Alert for: Henrietta Lacks}

Oprah To Producelmmortal Life Öf Hienrietta Lacks M̈OVIE For HBO

NEW YORK - Oprah Winfrey is joining with Alan Ball to produce an $\mathrm{HBO}$ film based on the nonfiction best-seller The lmmortal' Life of Henrietta Lacks.

wow. huffingtonpost com/ /oprah-to-produce-immortal n_ 5 ...

\section{Link:}

\section{Oprah To Produce 'Immortal Life Of Henrietta Lacks' MOVIE For HBO}
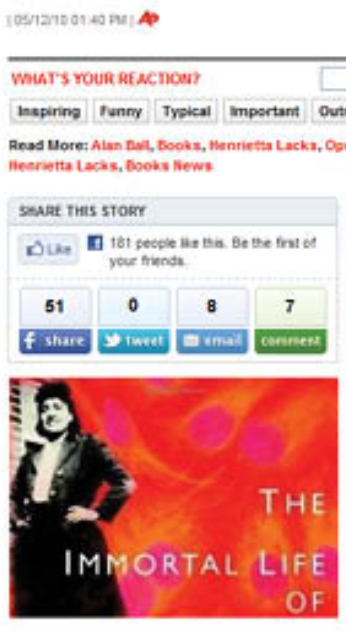

Get Books Alerts

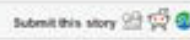
Facebook, and Google Buzz!

\section{-}

On the thet

nettpinumw hbo coet

Get HunfPost Books On Twitter.

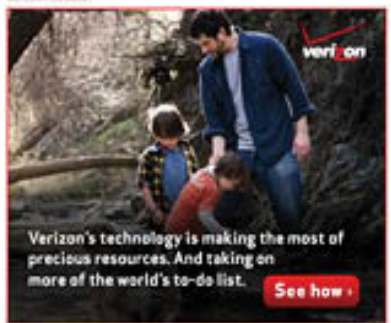

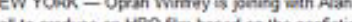
best-seler The Immonal L L te of Rementa Lacks. -

The setherk sais Wesnesday that Gall, createe and execulive prodicer of heO's drama series True Blosd, wil develop the project with Writrey and her the true story of Honsiotta Lacks, a poor black noman who died of centical cancer in 1951. Without ber consert. pieces of the tumer that kiled her were removed and used for mesical explicration and to culd a Bllon-dollaw mesearch insustry

No production schedule or air date for the film was sunced.

is ganned by Time Warner inc.

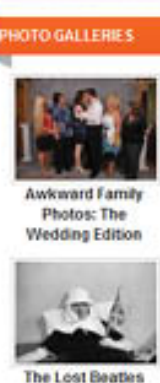

The Lest Beates
Phopograpts

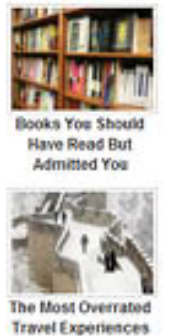

HUHFPOST SOCIAL NEWS

roctom to

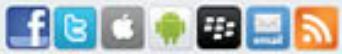




\section{Alert:}

The Catlin Coverslip: The Immortal Life of Henrietta Lacks

By Veronica

The Immortal Life of Henrietta Lacks by Rebecca Skloot is not a science book, nor is it a book about

the people who study science. It is about the rest of the people. Those who depend on science, and on

whom science depends: the people ...

The Catlin Cowerstip - httpilicoverslip blegspot com/

\section{Link (continued on next page):}

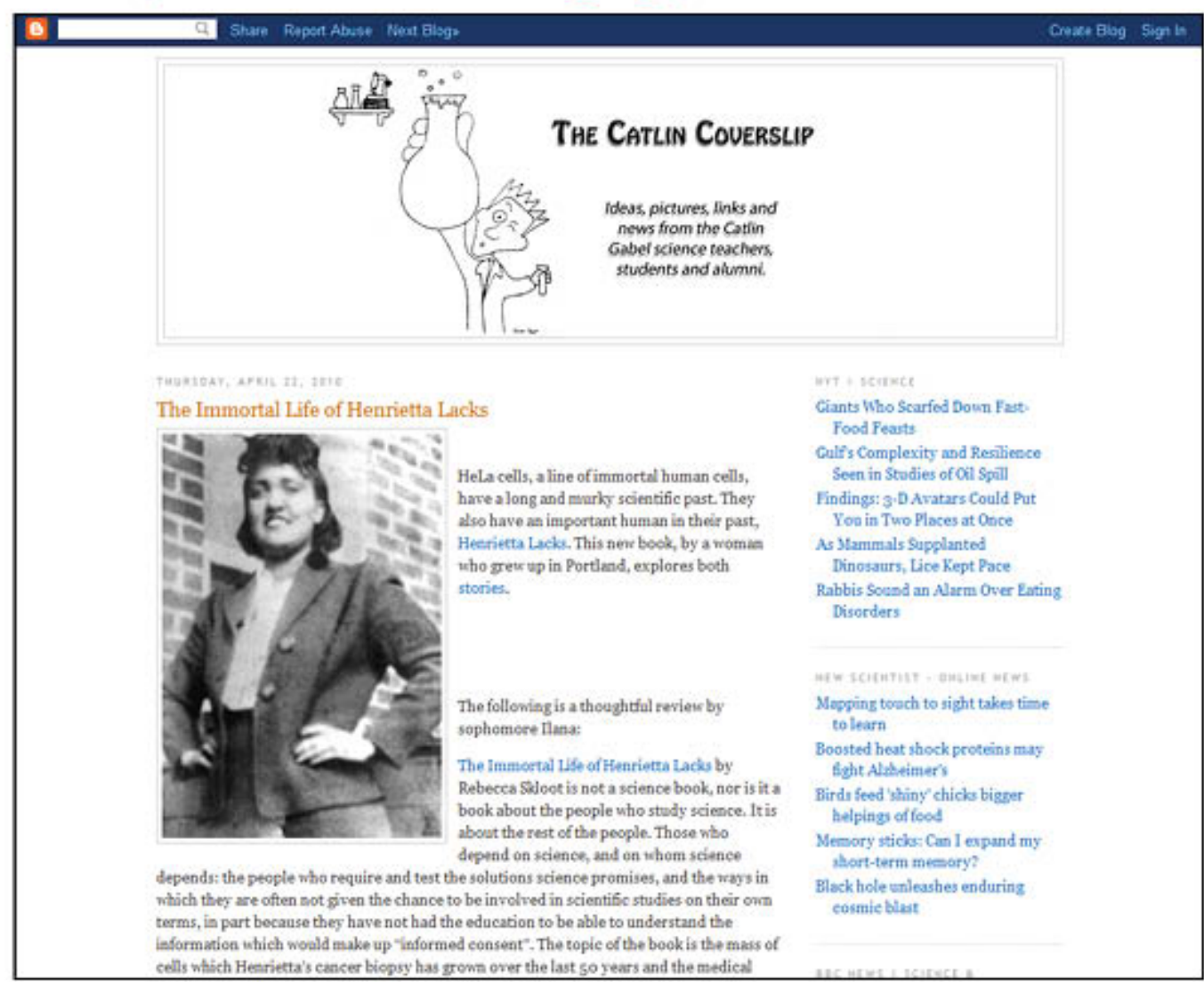


16.

\section{Link (continued):}

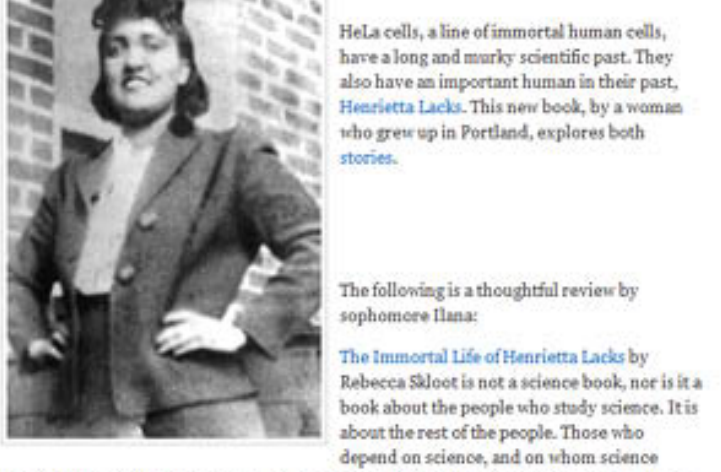

depends: the people who require and test the solutions seience promises, and the ways in Which ther are often not siven the chance to be inrolred in scientific studies on their ons terms, in part because they have not had the education to be able to understand the information uhich would make up 'informed consent". The topic of the book is the mass of cells which Hearietta's cances biopsy has growa orer the last go years and the medical advances those cells bave enabled, but the point of the book is to not be a science article to add to the $60,000+($ Skloot, p.312) articles concerning the cells which have already been publishod. The point of the book is to tell the story of Ifenrietta in human terms in equal parts a way for ber finely to come to terms and to an usderstanding of what was dene and why her cells are famous, and recomition of all of the unnamed people whose bodies have contributed to scientific achierement. Read this book to learn about the horrific clinical trials and inspiring scientific discoveries, Read this book slimpse the technicalities which have limited the abilities of lawyers to enact informed consent lates and to be aumed by the

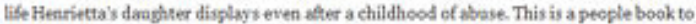
be recommended for its scientific value and its capacity to spark interest in fields from reporter, to lasyer, to scientist to human rights activist, and, if for po other reason, to earry ca the legacy of the person Henriecta iho wnhomingly gave her genes to seientific progress.

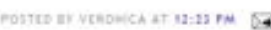

- COMMENTS:

POST A COMHENT

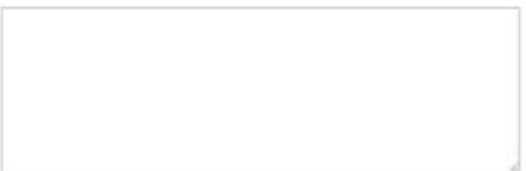

Comment as: Select profle -

Post Comment Preview (s)

Seen in Stoties of ot Spoill

Findings: 3.DAratars Could Put

Yor in Turo Places at Osce

As Mtammals Supplanted

Dinosaurs, Lice Kept Pace

Rabbis Sound an Alarm Over Eating

Diserders

yrw scirntom - oheter new

Meving terch to sight takes time to learn

Boosted hest shock proseins may Bght Alseimers

Birds feed whiny chicks bigger helpings of foed

Menory sticbs: Con 1 expand my fhort-term meesery?

Bisck locle unleashes enduring cosmic blast

\section{ac arws i acirect}

EnVRomerwi I wonL soirios

Japas raises nuelear crits level Earope' f future lies under Africa Laser gun fired from US navy ship Zimbabice's thino fescuet

boooured

Nitrogen pollation 'costs f $280 b e$ '

noO Axemint

- 2011 (4.3)

V $2010(71)$

- December (2)

- Norember (2)

- October (1)

- September (8)

- August (2)

- Duly (2)

- June (2)

- May (7)

- April (ni)

Some awesome rolcan

photos

Dance Lika Hosey Bees

Foreign Acceent Syedrome

The Immortal Life of Henrietta

lacks

Volcanes $=$ Good for the 


\section{7.}

\section{Alert:}

Web

1 new result for Henrietta Lacks

Immortal Life of Henrietta Lacks Tells a True Story of Science

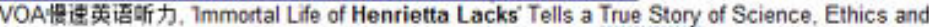

Family

Www cnielts com/VOAV73165 html

\section{Link:}

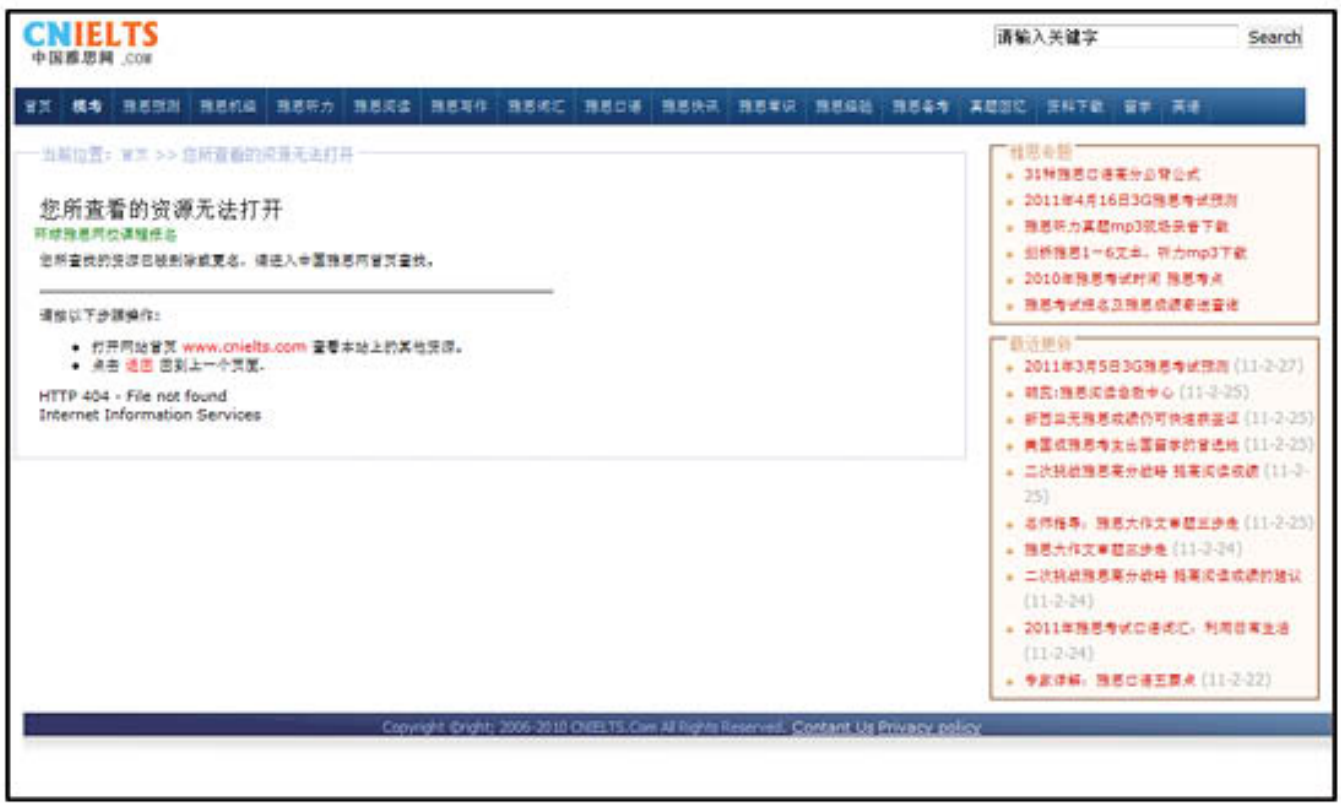




\section{8.}

\section{Alert:}

The Short Second Life of Bree Tanner: An Eclipse Novella ...

By admin

The Immortal Life of Henrietta LacksHer name was Henrietta Lacks, but scientists know her as

HeLa. She was a poor Southern tobacco farmer who worked the same land as her slave ancestors.

yet her cells-taken without her knowledge-became ...

$>\mid$ |BERIALIFE $\gg$ Redacion Heinz Duthel - http-//iberialife com/

\section{Link:}

Oops! Google Chrome could not find iberialife.com

Google

Suggestions:

- Seacti on Google.

iberia lite 2010 shon wecend bee tantegr ec Google Search

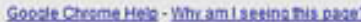

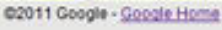




\section{9.}

\section{Alert:}

Manufacturers appeal for simplified carbon tax | WorldbbNews

By admin

Student fees hike 'may cut applications by half. Charity research finds high impact of university ...

Science Weekly podcast: The 'immortal' Henrietta Lacks. Rebecca Skloot tells us about Henrietta

Lacks, .... Sponsor ...

WorldbbNews - htto//worldbbnews com/

\section{Link:}

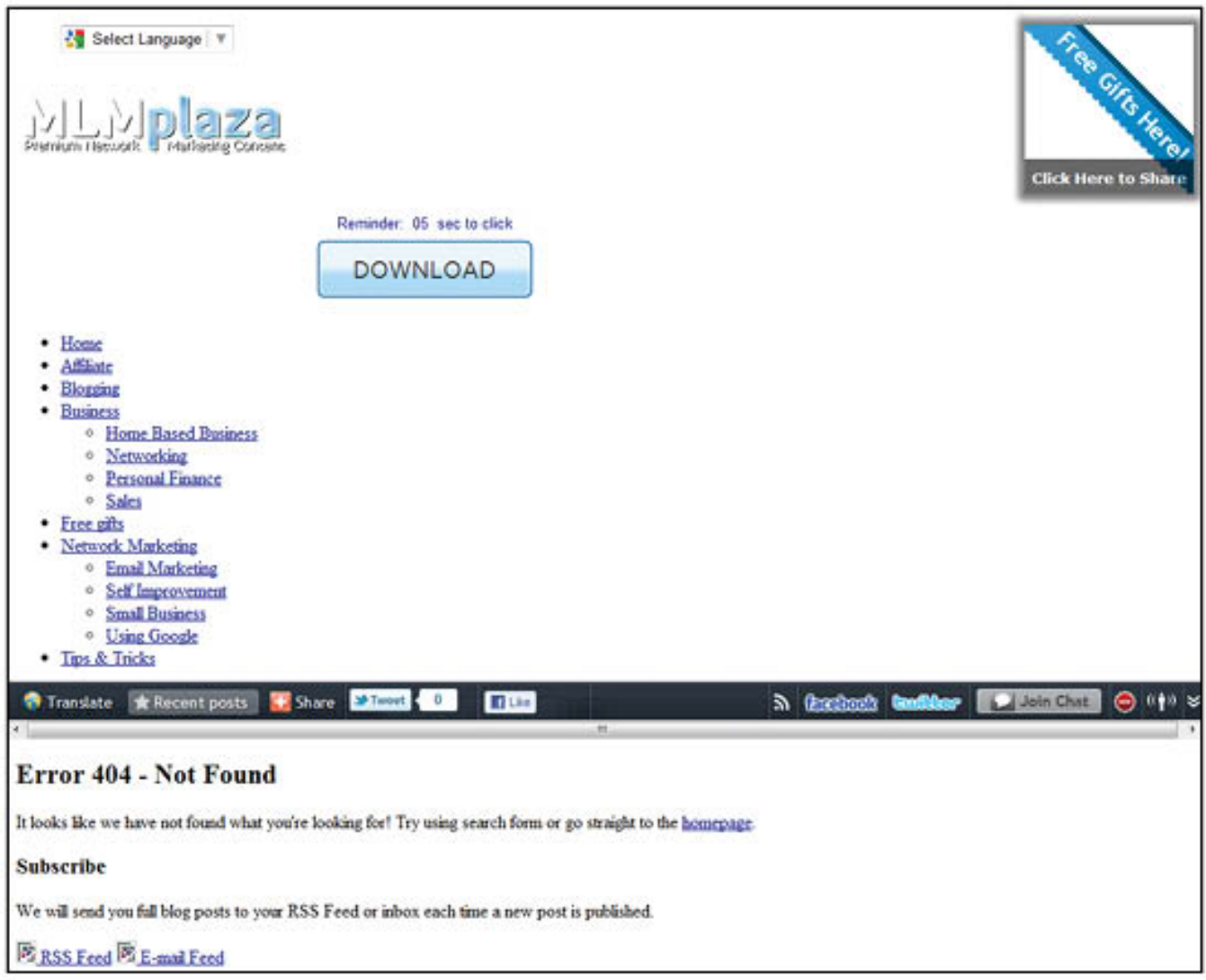


20.

\section{Alert:}

BOOKS-A-MILLION COM - Book: The Immortal Life of Henrietta Lacks

The Immortal Life of Henrietta Lacks. by Skloot, Rebecca - Add to Cart - Add to Wishlist. Pricing

Information. Membership Type Price. Retail Price: \$33.38 ...

unww. booksamillion com/product/A10312072845?id.

\section{Link:}

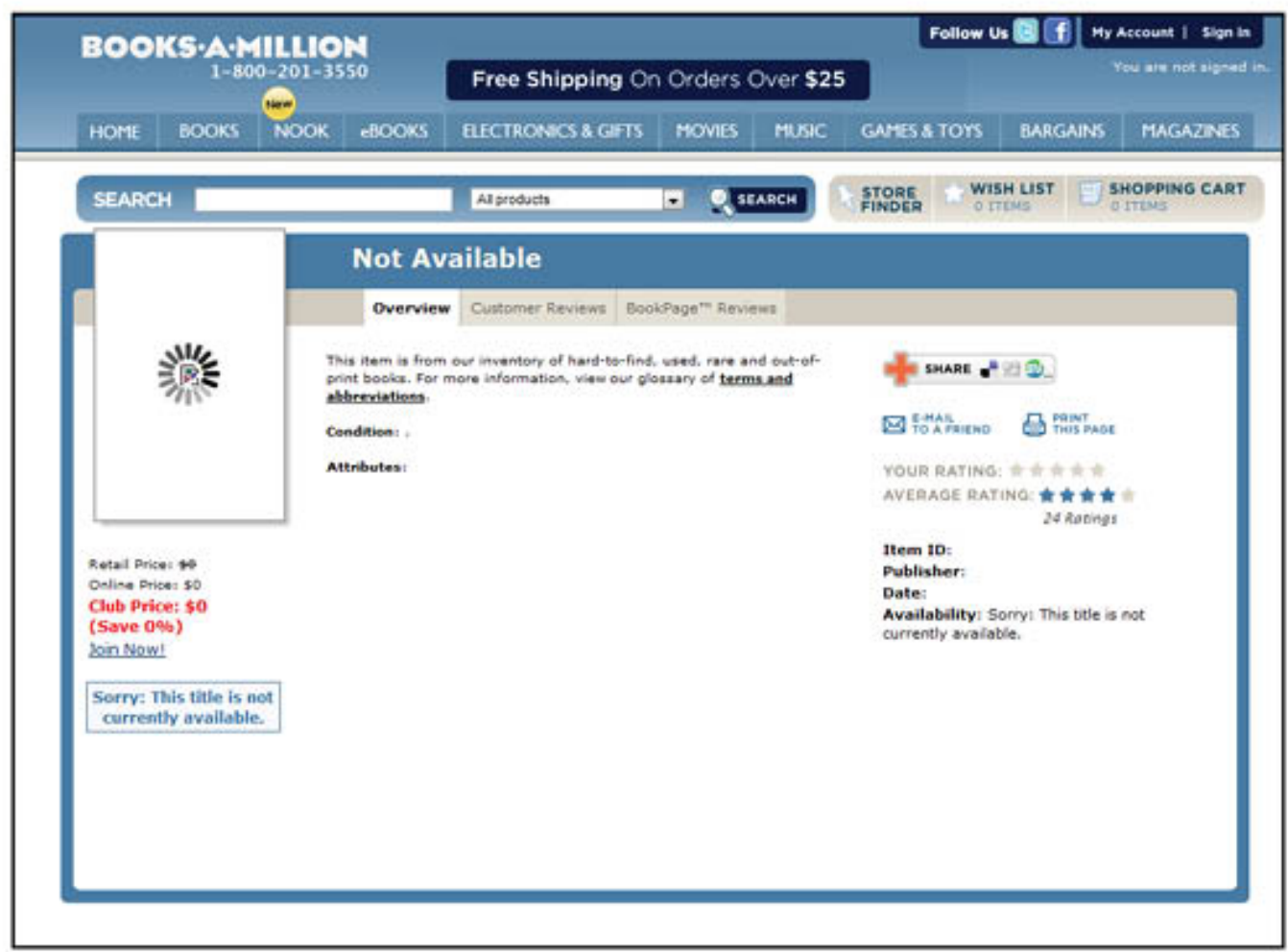




\section{Alert:}

\section{Google Blogs Alert for: Henrietta Lacks}

Guardian Podcast: Rebecca Skloot Discusses The Immortal Life of ...

By Rebecca

Guardian Podcast: Rebecca Skloot Discusses The Immortal Life of Henrietta Lacks. On Science

Weekly: The immortal "Henrietta Lacks. Alok Jha talks to Rebecca Skloot about the intriguing story of

Henrietta Lacks and why she has been so ...

Rebecca Skloot - http-l/rebeccaskloot com/

\section{Link:}

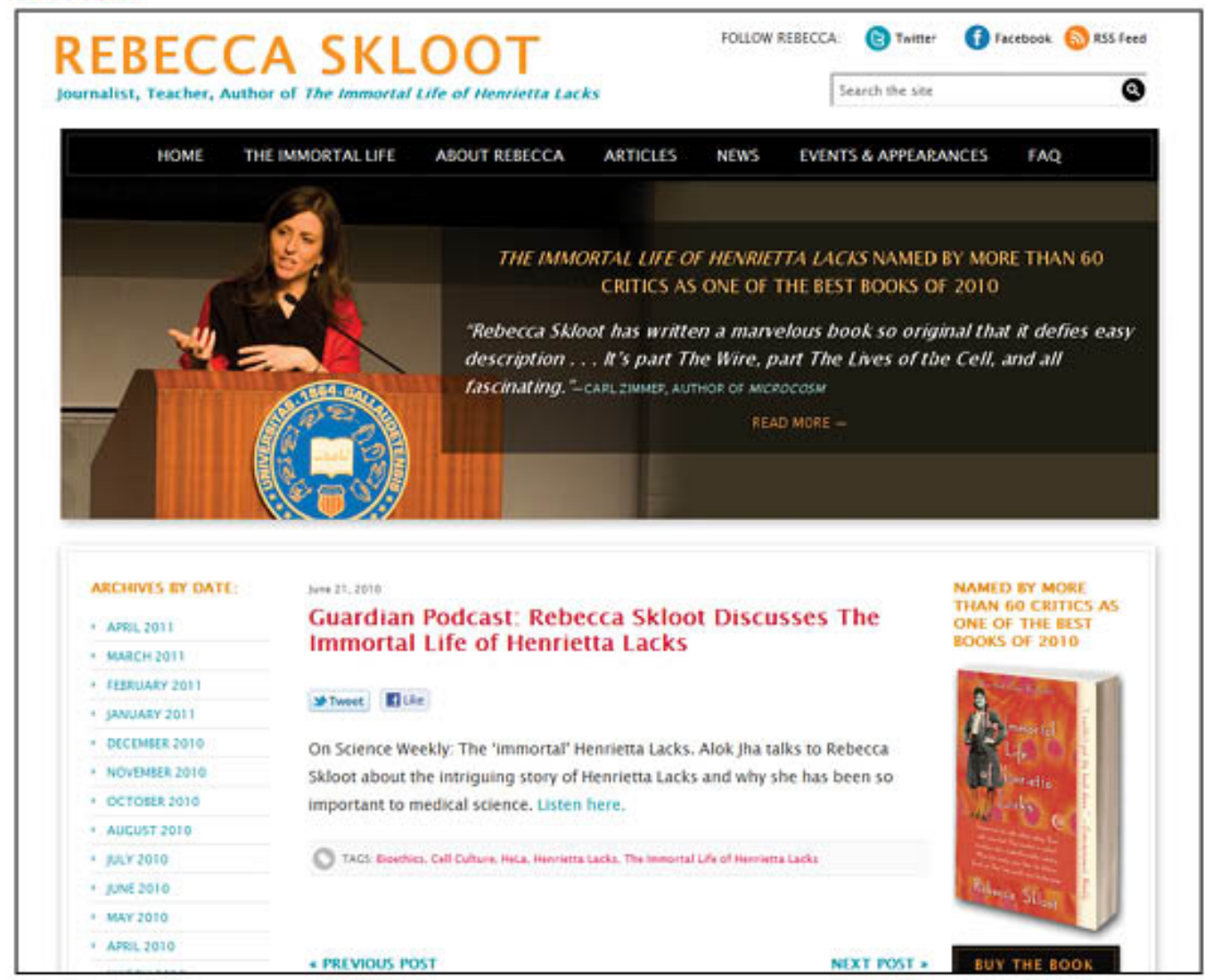




\section{Alert:}

lawyers - Demi Moore's lawyers threaten Boing Boing over photo ...

By 13865710

Read this: The Immortal Life of Henrietta Lacks.

http://www.computerworld. com/s/article/9142806/Court orders three H_1B sites disabled. brucegulick

| \#26 | 12:04 on Mon, Dec. 28 | Reply Report. If you wish to avoid reactions like this in ...

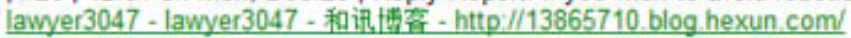

\section{Link:}

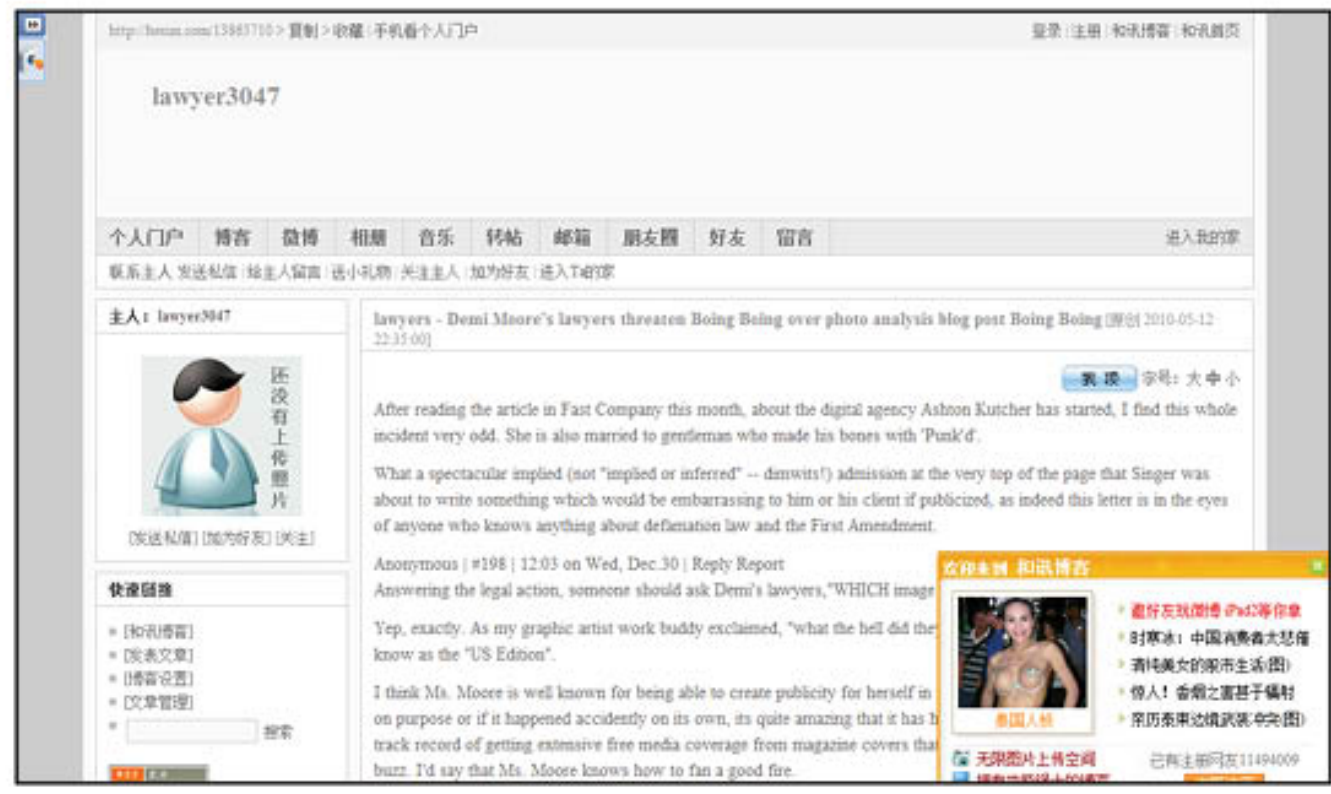




\section{Alert:}

immortal life of henrietta lacks Torrent Download - Torrent2Crazy

Download immortal life of henrietta lacks torrents, Download your favorite immortal life of henrietta lacks torrents at Torrent2Crazy, immortal life of ...

wnww.torrent2crazy. com/search/immortal+life+of thenrietta+lacks

\section{Link:}

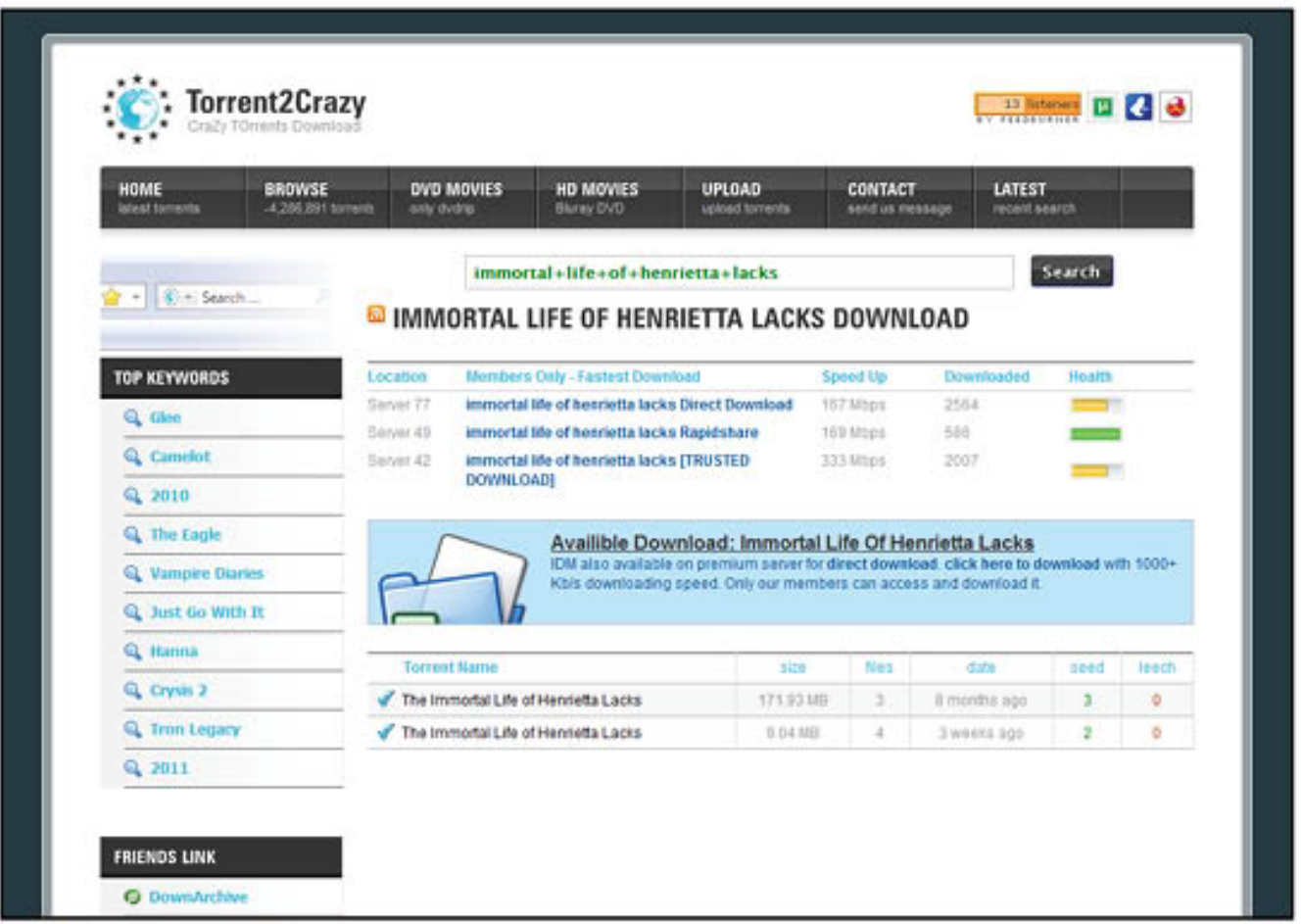




\section{APPENDIX C}

\section{AUTHOR BIOGRAPHY}

Melissa Shavlik received a Bachelor of Arts degree in Journalism (Advertising Emphasis) from Creighton University in Omaha, Nebraska. In 2011, she completed her Master of Science degree in Communication from Portland State University, in Portland,

Oregon. Shavlik is interested in digital media, science communication, design and public relations.

Correspondence concerning this paper should be addressed to Melissa Shavlik via email, atshavlik@yahoo.com. 